Lucas Manuel Cabral Teixeira

\title{
Tolerance towards wildlife in the Atlantic forest: an empirical test across ecological contexts and mammal species
}

Tolerância à fauna silvestre na Mata Atlântica: um teste empírico em diferentes contextos ecológicos e espécies de mamíferos

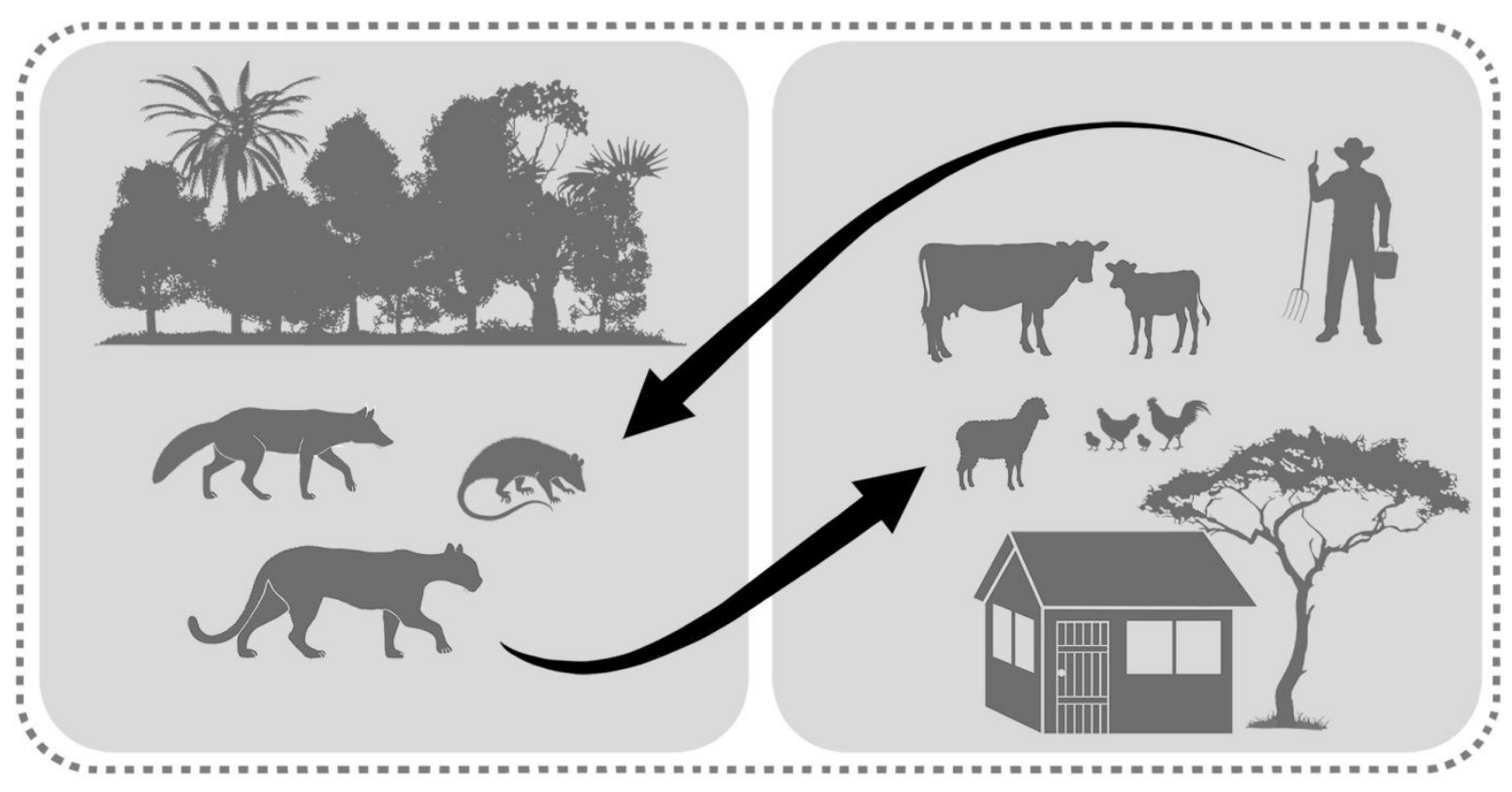

SÃo PAULO

2018 


\author{
UNIVERSIDADE DE SÃO PAULO \\ INSTITUTO DE BIOCIÊNCIAS \\ PRograma DE Pós-GRAdUAÇÃo EM ECOLOGIA
}

\title{
Tolerance towards wildlife in the Atlantic forest: an empirical test across ecological contexts and mammal species
}

\begin{abstract}
Tolerância à fauna silvestre na Mata Atlântica: um teste empírico em diferentes contextos ecológicos e espécies de mamíferos
\end{abstract}

\section{Lucas Manuel Cabral Teixeira}

Dissertação apresentada ao Instituto de Biociências da Universidade de São Paulo, para a obtenção de Título de Mestre em Ciências, na área de Ecologia.

Orientadora: Profa. Dra. Renata Pardini

SÃo PAULO

2018 


\section{Ficha CATAlográfica}

\section{Teixeira, Lucas Manuel Cabral}

Tolerance towards wildlife in the Atlantic forest: an empirical test across ecological contexts and mammal species.

Versão em português: Tolerância à fauna silvestre na Mata Atlântica: um teste empírico em diferentes contextos ecológicos e espécies de mamíferos.

$72 \mathrm{p}$.

Dissertação (Mestrado) - Instituto de Biociências da Universidade de São Paulo. Departamento de Ecologia.

1. Human-wildlife interactions 2. Socioecological systems 3. Wildlife management 4. Ecosystem disservices 5. Leverage points 6. Biodiversity conservation. I. Universidade de São Paulo. Instituto de Biociências. Departamento de Ecologia.

Versão em português: 1. Interações seres humanos-fauna silvestre 2. Sistemas socioecológicos 3. Manejo de fauna 4. Desserviços ecossistêmicos 5. Pontos de alavancagem 6. Conservação da biodiversidade. I. Universidade de São Paulo. Instituto de Biociências. Departamento de Ecologia.

\section{COMISSÃO JULGADORA}

$\operatorname{Prof}(a) . \operatorname{Dr}(a)$.

Prof(a). Dr(a).

$\operatorname{Prof}(\mathrm{a}) . \operatorname{Dr}(\mathrm{a})$.

Profa. Dra. Renata Pardini

Orientadora 
A MINHA AVÓ AlZIRA E A MEU AVÔ ROLDÃo (in memorian),

que, por terem me ensinado, dentre tantas coisas (!), o cultivar das hortaliças no quintal e o respeito aos animais na roça, podem ser considerados o motivo de eu estar aqui-apesar de nunca entenderem muito bem o porquê do que faço... 
"One of the anomalies of modern ecology is the creation of two groups, each of which seems barely aware of the existence of the other. The one studies the human community, almost as if it were a separate entity, and calls its findings sociology, economics and history. The other studies the plant and animal community and comfortably relegates the hodge-podge of politics to the liberal arts. The inevitable fusion of these two lines of thought will, perhaps, constitute the outstanding advance of this century" 


\section{AgRADECIMENTOS / ACKNOWLEDGMENTS}

Em sua Summa Theologiae, o filósofo Tomás de Aquino reconhece três níveis de gratidão: o reconhecer (ut recognoscat), o dar graças (ut gratias agat) e o retribuir (ut retribuat), sendo este último o mais profundo nível de gratidão. Para ele, ut retribuat vai além do plano cognitivo, gerando um sentimento de vínculo, de obrigação para com aquelas pessoas que se prontificaram a ajudar. Nesse sentido, a língua portuguesa é, talvez, uma das poucas que permitem expressar verbalmente o terceiro nível de gratidão proposto pelo filósofo. Assim,

à Coordenação de Aperfeiçoamento de Pessoal de Nível Superior (CAPES) e ao Conselho Nacional de Desenvolvimento Científico e Tecnológico (CNPq),

pela bolsa de estudos concedida nos primeiros meses do curso de mestrado, pelo apoio financeiro fornecido às atividades do programa de pós-graduação em Ecologia e pela bolsa de produtividade em pesquisa concedida a minha orientadora;

à Fundação de Amparo à Pesquisa do Estado de São Paulo (FAPESP), pela bolsa de estudos (2016/06789-3), que viabilizou minha estadia em São Paulo durante o curso mestrado, e pelo financiamento do projeto temático Interface (2013/23457-6), ao qual esta pesquisa está vinculada;

ao Instituto de Biociências e ao Programa de Pós-graduação em Ecologia do IB-USP, especialmente às secretárias do programa, Vera e Shirlene,

pelo apoio institucional, pedagógico e logístico que tornam possível o desenvolvimento deste curso e das pesquisas através dele realizadas;

a minha orientadora, Renata,

por acreditar em mim quando eu não acreditava; por, apesar de minhas falhas, ser paciente e ter compreensivamente me estendido a mão e orientado no árduo caminho rumo à fronteira do conhecimento acadêmico; por ter me dado a alegria, para não dizer a honra, de ser seu aluno;

to my advising committee, Ine Dorresteijn and Silvio Marchini,

for accepting to board onto this adventurous research topic with us, not measuring efforts to always and thoughtfully help us sail through this bustling sea, despite the distances - and the ocean! - between us; for giving me the pleasure to work with you (again!);

a minha colega e amiga Karina,

por ter sido não apenas uma colega de trabalho, mas uma verdadeira cúmplice e companheira de equipe; por ter me ajudado nos momentos difíceis - profissionais e pessoais; por ter tornado este caminho mais leve e fácil de ser percorrido através de palavras serenas, mansidão e conhecimento invejáveis;

a minhas amigas e amigos da Casa das Vespas, especialmente Lari, Fer, Vini e Vivi, por terem sido uma verdadeira família durante uma parte muito importante desta pesquisa, lá atrás em 2015, quando ela era apenas uma semente; por terem me dado dicas preciosas de campo, GIS, R, e mostrado caminhos (no sentido figurado ou não!) que tornaram o desenvolvimento deste trabalho muito mais fácil; 
a todas minhas amigas e amigos do DICOM, nativos e agregados, pela amizade e companheirismo, pelas conversas e discussões, pelas críticas e revisões, pelos (saudosos!) happy hours. Especialmente a Gabi, pela disponibilidade em ajudar com as análises dos dados mesmo em meio a tantas outras coisas a fazer;

a todas e todos colegas do LEPAC,

pelos arquivos e mapeamentos fornecidos, pelo apoio logístico do projeto, pelos workshops realizados e conhecimento compartilhado. Especialmente ao Prof. Jean Paul, por coordenar o Projeto Interface, que viabilizou grande parte desta pesquisa;

a minhas amigas e amigos do curso de pós-graduação, já titulados ou não,

pelas discussões científicas que tanto contribuíram para que eu me tornasse um profissional mais crítico, pelo espírito de equipe na realização das atividades promovidas por estudantes e, claro, pela amizade cultivada. Especialmente a Luanne e Rodolfo, pelo companheirismo não apenas nas atividades do programa ou nas disciplinas que cursamos juntos, mas também nessa pauliceia desvairada que, carinhosamente (!), chamamos de lar ao longo desses anos;

a todas as pessoas que aceitaram participar desta pesquisa, por compartilhar um "minutinho" (minutinho?!) de seu tempo, abrindo suas casas e suas histórias, muitas vezes acompanhadas de um cafezinho quase mineiro de aquecer o coração que me levava de volta a minhas origens, tornando possível a obtenção destes resultados;

ao pessoal de Joanópolis, especialmente à família do Seu Percival, da D. Esmeralda e Andrea, pelo apoio com a hospedagem durante o campo, pela ajuda com os problemas que apareciam e pelas dicas que só pessoas com um profundo conhecimento da área poderiam nos dar;

a minhas amigas e amigos, de Minas e, especialmente, a minha família em São Paulo, Uairigatô: Aline, Nádia, Leandro, Vítor e Paulinha,

por estarem sempre ao meu lado e serem um porto seguro nesta cidade tão maravilhosa e tão difícil; pela compreensão e disposição, sempre que preciso - ou nem tanto! - em compartilhar um abraço, uma palavra de conforto e/ou uma garrafa de vinho;

a meu namorado Eduardo,

pelo carinho e compreensão durante todo este processo, especialmente na fase final; por acreditar em minhas ideias descabidas, adentrando-se comigo em aventuras surreais que jamais seriam tão boas sem sua presença; e, claro, pela ajuda com as figuras (!);

especialmente, a minha mãe Idelma, meu "paidrasto" Wandinho e, ainda que ausente, ela e sempre ela, Isabella, minha irmã,

por me darem a imensurável felicidade de ser seu filho e irmão, por terem tornado essa conquista possível graças a um suporte incondicional; pela segurança de saber que estavam ali, fundamental para que eu pudesse continuar neste caminho;

a Deus, enfim,

por conduzir meus passos no caminho da retidão, do respeito e do amor às pessoas em meio a um mundo tão apático, permitindo-me enxergar que ainda há esperanças; 


\section{CONTENTS}

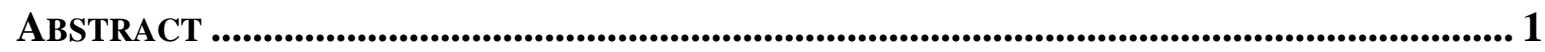

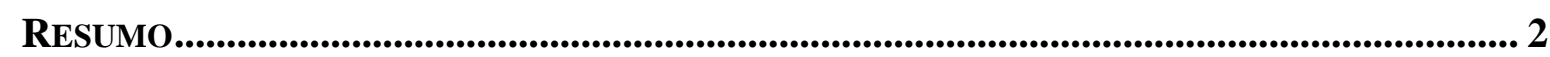

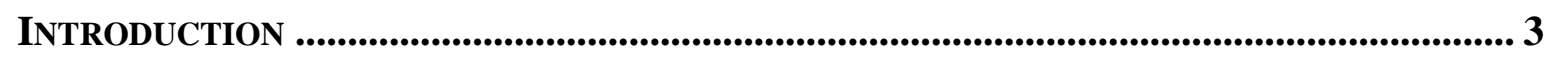

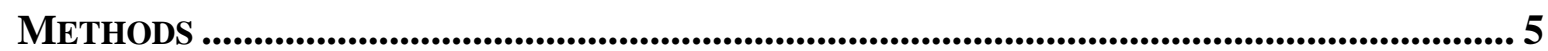

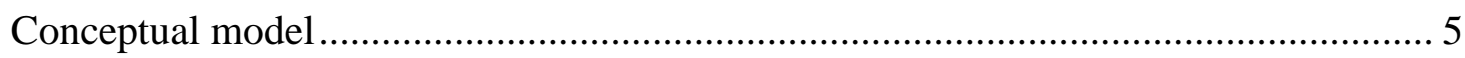

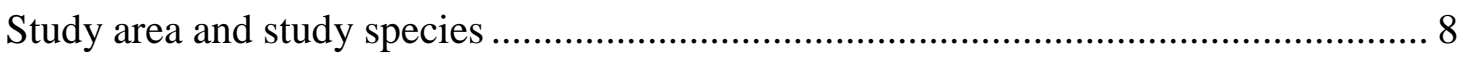

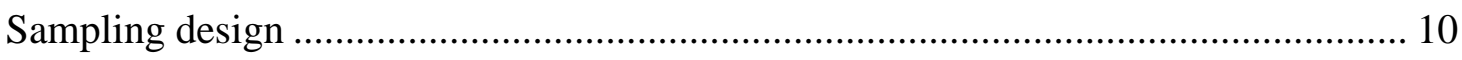

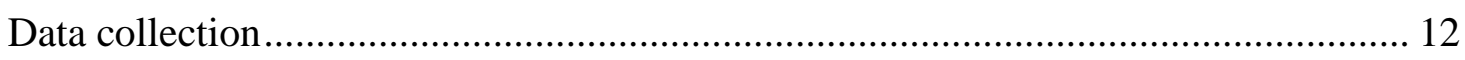

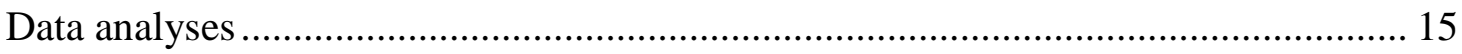

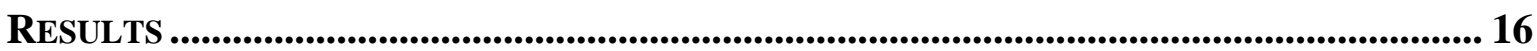

Characterization of the sampled population ........................................................... 16

Piecewise Structural Equation Modeling ............................................................... 18

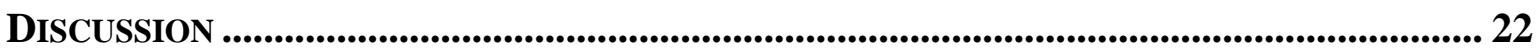

Pathways connecting ecological context and tolerance - comparisons across

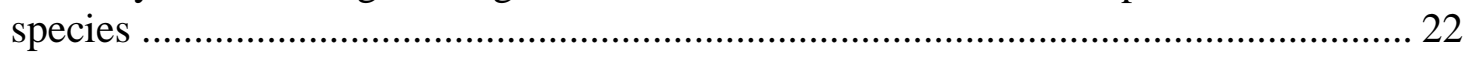

Contributions to the study of human-wildlife conflicts.......................................... 25

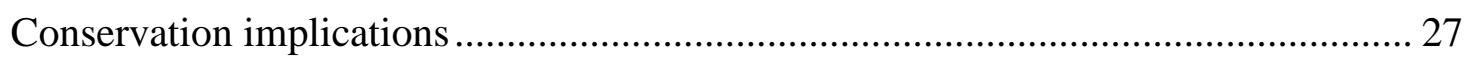

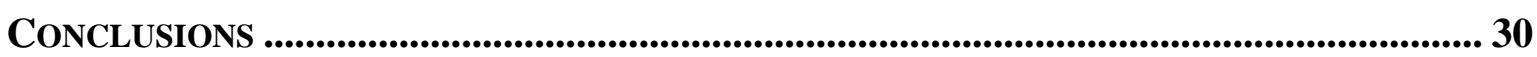

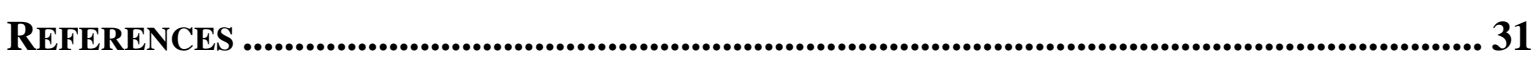

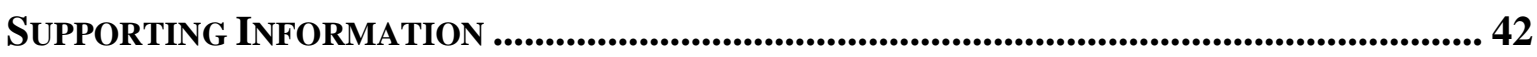

Appendix A - Selection of properties and interviewees ...................................... 42

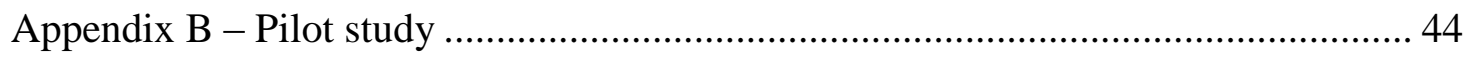

Appendix C - Socio-demographic variables, raised livestock and dependence on

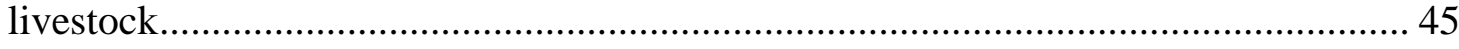

Appendix D - Identification of the target species ................................................... 46

Appendix E - Quantifying experiences with the target species ................................. 48

Appendix F - Quantifying psychological variables towards the target species........... 49

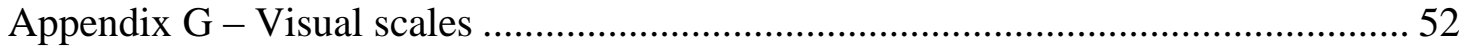

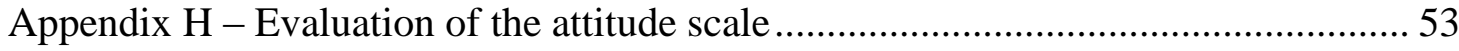

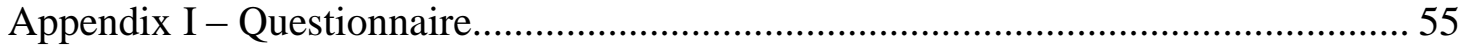

Appendix J - Defining the distributions and link functions ........................................6. 67

Appendix K - Inclusion of the missing paths suggested by the analysis ..................... 69 


\begin{abstract}
Human-wildlife conflicts (HWC) emerge as complex conservation challenges impairing human livelihood and wildlife populations. Research on HWC, however, has traditionally approached these components apart and focused on single/ similar species, hampering a broader understanding of the connections between ecological drivers and human dimensions of conflicts. We here develop and test a model integrating ecological and human components of HWC, focusing on three species - opossum, crab-eating fox and puma. We investigated the pathways through which the ecological context (forest cover) affects experiences with wildlife (contact and damage), and how such experiences influence tolerance via beliefs, emotions and attitude. We interviewed 114 landowners across 13 landscapes varying in forest cover in a region of the Brazilian Atlantic forest and tested our model using Piecewise Structural Equation Modeling. We found that: i. forest cover negatively affected tolerance, but just towards the largest species; ii. relevance and effects of distinct experiences with wildlife on beliefs and emotions varied across species; iii. beliefs and emotions influenced tolerance, but negative emotions were relevant only for the largest species. Conflicts with larger species can then be understood as disservices provided by forests, indicating the relevance of framing HWC within a broader perspective that consider the trade-offs with ecosystems services. For some species, positive experiences with wildlife may counteract the negative effects of damages to livestock in shaping human behavior. Models such as ours - that structure relationships between ecological and human components - can help identifying deeper, more effective leverage points to improve interventions to mitigate HWC.
\end{abstract}




\section{RESUMO}

Conflitos entre seres humanos e fauna silvestre emergem como desafios complexos, ameaçando o sustento de populações humanas e a conservação de populações de animais silvestres. Contudo, pesquisas sobre conflitos tradicionalmente abordam esses componentes separadamente e focam em espécies individuais ou similares, dificultando o entendimento mais amplo das conexões entre determinantes ecológicos e dimensões humanas dos conflitos. Neste estudo, desenvolvemos e testamos um modelo conceitual integrando componentes ecológicos e humanos dos conflitos, focando em três espécies - gambá, cachorro-do-mato e onça-parda. Investigamos os caminhos através dos quais o contexto ecológico (cobertura florestal) afeta experiências (contato e dano), e como tais experiências influenciam a tolerância à fauna por meio de crenças, emoções e atitude. Entrevistamos 114 proprietários rurais em 13 paisagens com diferentes proporções de cobertura florestal em uma região da Mata Atlântica e testamos nosso modelo usando equações estruturais do tipo Piecewise. Encontramos que: i. a cobertura florestal afetou negativamente a tolerância, mas apenas para a maior espécie; ii. a importância e os efeitos de diferentes experiências com a fauna sobre crenças e emoções variaram entre as espécies; iii. crenças e emoções influenciaram a tolerância, mas emoções negativas foram relevantes apenas para a maior espécie. Conflitos com espécies maiores podem então ser entendidos como desserviços providos por florestas, indicando a relevância de inserir os conflitos humano-fauna em perspectiva mais ampla, que considere as relações com serviços ecossistêmicos. Para algumas espécies, experiências positivas podem compensar os efeitos negativos dos danos a criações na formação do comportamento humano. Modelos como o nosso - que estruturem as relações entre os componentes ecológicos e humanos - podem ajudar a identificar pontos de alavancagem mais profundos e efetivos para melhorar intervenções visando a mitigação dos conflitos com a fauna. 


\section{INTRODUCTION}

Among the different ways humans can interact with wildlife (Conover, 2002; Peterson et al., 2010), human-wildlife conflicts (HWC) emerge as one of the most challenging conservation issues (Dickman, 2010). This is because human-wildlife conflicts not only negatively impact wildlife populations, but also hamper human livelihoods (Madden, 2004). Moreover, these conflicts frequently lead to disagreements among different groups of actors, especially those who seek to conserve wildlife (Lute et al., 2018) and people with other interests (Peterson et al., 2010). As such, HWC are processes of interaction between ecological and human systems, and understanding and managing these conflicts depends on considering both the ecological context they occur and their social complexity (Røskaft et al., 2007; Dickman, 2010; Redpath et al., 2013; Carter et al., 2014).

Studies on HWC, however, have traditionally approached the ecological and human components of conflicts apart. On the one hand, ecological research on human-wildlife conflicts have revealed that prey availability (both native and livestock; Patterson et al., 2004; Kissui, 2008; Lyamuya et al., 2014), vegetation type (Miller, 2015; Minnie et al., 2015), landscape structure and distance to native vegetation (Soto-Shoender \& Giuliano, 2011; Thorn et al., 2012) are important ecological drivers of wildlife attacks to livestock and crops. Such attacks from wildlife may then be considered as a type of ecosystem disservice (Dorresteijn et al., 2017; Rasmussen et al., 2017) and a key experience with nature that depends on the ecological context and enhances human-wildlife conflicts (Woodroffe et al., 2005). Yet, most studies on HWC focusing on ecological drivers do not simultaneously encompass the effects of wildlife attacks on shaping human behavior.

On the other hand, much of the research on human dimensions of HWC has approached a range of social and psychological antecedents of human behavior towards wildlife. Among those, perception of risks and benefits (Carter et al., 2012; Inskip et al., 
2014), as well as emotions (Jacobs, 2012) and attitude towards wildlife (Marchini \& Macdonald, 2012; Kansky \& Knight, 2014) are recognized as important to how people respond to wildlife. More recently, tolerance (Bruskotter \& Wilson, 2014; Inskip et al., 2016), a concept used in the wildlife management literature, has been applied to understanding human-wildlife conflicts (Kansky et al., 2016). However, not only different definitions have been applied to these concepts (Bruskotter et al., 2015), but also a range of different factors (Kansky \& Knight, 2014), including wildlife attacks (Zimmermann et al., 2005; Kissui, 2008; Thorn et al., 2012), have been proposed and tested as shaping human behavior. This heterogeneity hinders a broader understanding of the human dimensions of conflicts.

Hence, despite the evidences suggesting that experiences with nature influence people support towards conservation (Zaradic et al., 2009; Zhang et al., 2014), few HWC studies attempted to simultaneously account for how the ecological context determines people experiences with wildlife and how those experiences shape the antecedents of human behavior towards wildlife (but see van Velden et al., 2016; Behr et al., 2017). Moreover, most studies on HWC have frequently focused on groups of larger carnivores or single charismatic species (Carter et al., 2012; Inskip et al., 2014; Alexander et al., 2015; Palmeira et al., 2015), and neglected conflicts with smaller wildlife (Peterson et al., 2010), hampering the understanding of how human responses can change across species. We here develop and empirically test a conceptual model (Figure 1) that combines the ecological and human dimensions of conflicts, considering multiple landscapes and wildlife species in the Atlantic forest of Brazil.

The Atlantic forest is a highly threatened biodiversity hotspot (Myers et al., 2000), harboring around $70 \%$ of the Brazilian population and a considerable part of the country agricultural production. Human occupation has converted most of the forest, today restricted to less than $16 \%$ of the original cover (Ribeiro et al., 2009). Despite this scenario that makes 
understanding and mitigating human-wildlife conflicts in this region crucial to both biodiversity conservation and the livelihoods of rural people, few HWC studies have been carried in the Atlantic forest (Palmeira et al., 2015; Engel et al., 2016), focusing mostly on large carnivores.

Considering that the amount of habitat in a landscape determines the abundance and movements of wild mammals (Fahrig, 2003; Tucker et al., 2018), which in turn should increase the chance of people having experiences with wildlife, we aim at identifying the relevant pathways through which the ecological context affects the attitude and tolerance of rural people towards wildlife. Specifically, we intend to investigate (1) if the ecological context - here represented by native forest cover at the landscape - affects the contact people have with mammals and/or the damages resulting from attacks to livestock, (2) if these experiences affect positive and/or negative beliefs and emotions towards mammals, and (3)

which of these beliefs and emotions are more important to shaping attitude and tolerance towards them (Figure 1). Because the effects of experiences with wildlife can vary (Kansky et al., 2014) depending on species traits such as size, rarity and diet, we also intend to compare the relevant pathways through which the ecological context affects attitude and tolerance across three species varying in these characteristics: the opossum (Didelphis aurita), the crabeating fox (Cerdocyon thous) and the puma (Puma concolor).

\section{METHODS}

\section{Conceptual model}

A large body of evidence indicates the importance of the amount of native habitat at the landscape in determining not only wildlife abundance (e.g., Kinnaird et al., 2003; Michalski \& Peres, 2007), but also the proximity of wildlife populations to human settlements as well as the frequency and range of animal movements (Thorn et al., 2014; Tucker et al., 
2018). Hence, people living in landscapes with higher native habitat cover are expected to have more experiences with wildlife (Figure 1), not only by suffering damage, such as livestock depredation more frequently (Soto-Shoender \& Giuliano, 2011; Goswami et al., 2015), but also by having a higher probability of encountering wildlife (Llaneza et al., 2016; Kshettry et al., 2017). In turn, experiences are known to shape beliefs and emotions associated with wildlife (Røskaft et al., 2007; Heberlein, 2012; Jacobs, 2012). Based on previous studies, we assume that, while attacks to livestock have a negative effect (Alexander et al., 2015; Li et al., 2015) on beliefs and emotions towards wildlife, contact with wildlife, through greater knowledge on the species (Lescureux \& Linnell, 2010; Piédallu et al., 2016; Reibelt et al., 2017), should have a positive effect (Figure 1).

In the HWC literature, different terms have been used to address beliefs, such as (perception of) benefits and risks or intangible costs (Zajac et al., 2012; Bruskotter \& Wilson, 2014; Inskip et al., 2014; Kahler \& Gore, 2014; Inskip et al., 2016). Similarly, emotions have been addressed within HWC research under names such as feelings and affections (Vaske et al., 2013; Sponarski et al., 2016; Wald et al., 2016). According to the Theory of Planned Behavior (TPB; Ajzen, 1991), a psychological framework that has been frequently applied to understand people responses to environmental problems (e.g., Marchini \& Macdonald, 2012; Leeuw et al., 2015; Borges et al., 2016), beliefs represent specific positive or negative ideas people hold regarding a psychological object (Fishbein \& Ajzen, 2011). Hence, perception of risks and benefits associated with wildlife represent beliefs. In contrast to beliefs, that are generally understood as the cognitive component, emotions represent the affective component of human psyche (Phelps, 2006). Emotions may not only affect how strong beliefs people hold towards a psychological object are, but also people may hold beliefs about emotions they experience towards an object (Ajzen, 2011). Beliefs about the emotions associated with psychological objects have been shown to improve the quality of predictive models of human 
intention and behavior (Sandberg \& Conner, 2008). We then included in our model both beliefs on the benefits and risks brought about by wildlife (i.e., positive and negative beliefs) and positive and negative emotions people believe these species bring them (Figure 1).

Beliefs are in turn predictors of attitude (Figure 1), a concept from psychology that defines how favorable a person is in relation to a psychological object (Fishbein \& Ajzen, 2011). Although attitude towards wildlife has been extensively applied to the study of HWC (Kansky \& Knight, 2014), some consider it as a synonym of tolerance (also called acceptance; Bruskotter et al., 2015). We define tolerance as proposed by Bruskotter \& Wilson (2014): a passive acceptance of a wildlife population. This definition assumes that the human default is taking no action to injure wildlife, but there is a threshold in wildlife population level above which the individual is motivated to act to reduce wildlife population (Bruskotter \& Fulton, 2012) by performing an intolerant behavior. Frank (2016) suggests an attitudinal gradient of tolerance: the more favorable the attitude of a person towards wildlife, the more tolerant towards wildlife a person is, so we propose attitude as an antecedent of tolerance (Figure1).

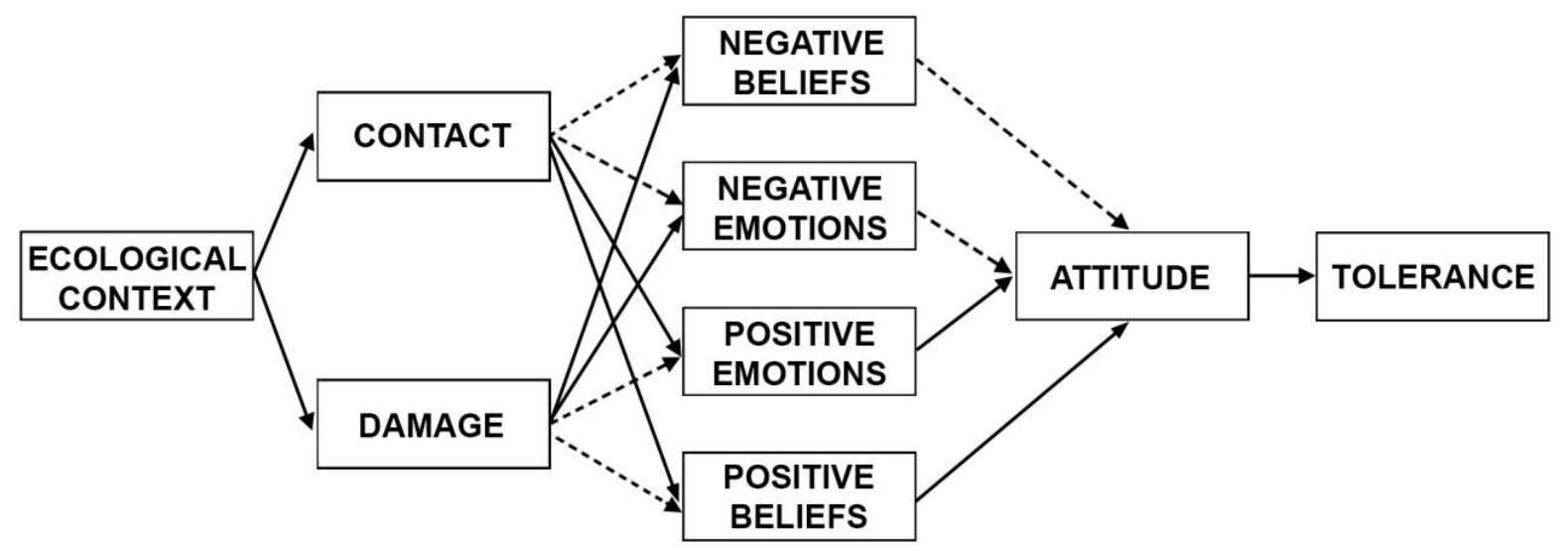

Figure 1. Conceptual model of how the ecological context should affect tolerance towards wildlife. Arrows indicate causal links between variables (rectangles). Continuous arrows indicate positive effects and dashed arrows indicate negative effects. Ecological context $=$ proportion of native forest cover around households; Contact $=$ contact with the species; Damage $=$ attacks to livestock caused by the species; Negative and positive beliefs = perception of risks and benefits associated with the species, respectively. Positive and negative emotions $=$ emotions people believe wildlife will bring them, with positive and negative valence, respectively. Attitude $=$ attitude towards the species; Tolerance $=$ tolerance towards the species. 


\section{Study area and study species}

The study was conducted in an area covering about 300,000 ha in the Atlantic Plateau of São Paulo, Brazil (Figure 2), encompassing ten municipalities. The rural areas of the study region harbors around 50,000 inhabitants, with 1.9 to $49.8 \%$ of the population across municipalities living in rural areas (IBGE, 2010; 2017). Rural properties vary extensively is size, from less than 1 to 4095 ha ( $28 \pm 104$ ha, on average). Of the area used for farming activities in the region, $54 \%$ is used for pastures, $32 \%$ for crops and $14 \%$ for silviculture, being dairy cattle the main farming activity in the region (IBGE, 2006).

The region was once covered by montane Atlantic forest, restricted nowadays to fragments in early to mid stages of succession, mainly within rural properties (Figure 2). Climate in the region is humid subtropical (CEPAGRI, 2018), with elevation above 700 m.a.s.l. The mean of the minimum and maximum monthly temperature is $11.3^{\circ} \mathrm{C}$ and $24.6^{\circ} \mathrm{C}$ in the colder season (April to September) and 14.8 and $27.7^{\circ} \mathrm{C}$ in the warmer season (October to March), and the mean annual rainfall is $1513 \mathrm{~mm}$ (CEPAGRI, 2018).

As observed in other Atlantic forest regions (e.g., Cullen et al., 2000; de Angelo et al., 2011; Espartosa et al., 2011; Jorge et al., 2013), poaching, retaliation and habitat loss have led to a simplified mammal community in the study region. Although larger species such as jaguars (Panthera onca), tapirs (Tapirus terrestris) and white-lipped peccaries (Tayassu pecari) are no longer found, a variety of native species ranging in size and level of rarity from pumas (Puma concolor), collared peccaries (Pecari tajacu), collared anteaters (Tamandua tetradactyla) and brocket deer (Mazama spp.) to several smaller carnivores, such as coatis (Nasua nasua), racoons (Procyon cancrivorus), wild cats (Leopardus spp.), crabeating fox (Cerdocyon thous) and tayras (Eira barbara), and medium-sized marsupials, such as the opossums (Didelphis aurita) - are still present in the study region (Ribeiro, 2016). 
From those, we focused on species that are known to attack different livestock - the most common farming activity in the study region, but vary in size and rarity: the opossum (Didelphis aurita), the crab-eating fox (Cerdocyon thous) and the puma (Puma concolor). The opossum is a common, medium-sized marsupial known to frequently attack chicks and eggs (Lobao \& Nogueira-Filho, 2011). Although attacks from opossum may be frequent as the species is abundant and considered synanthropic (Horta et al., 2007; Melo et al., 2016), the impacts on people livelehoods may be low as they prey small livestock. However, the species can transmit diseases, such as Chagas' disease (Miles et al., 2003; Yeo et al., 2005) and tick typhus (Bermúdez et al., 2017), and is frequently confound with rats, being commonly repulsed by people. The crab-eating fox is a widely distributed canid, which, as other Neotropical canids, frequently attacks chickens and other poultry (Hunter \& Barrett, 2011). The species is relatively common and is frequently seen in pairs along dirty roads and near forest edges. The puma is a large felid, and the largest carnivore in the study region. Although relatively rare, it is less sensitive to human disturbances than other large felids such as the jaguar (Sunquist \& Sunquist, 2017). As other large carnivores, pumas are frequently involved in human-wildlife conflicts for attacking livestock of more economic value, such as cattle, horses and sheep (Palmeira et al., 2015). 


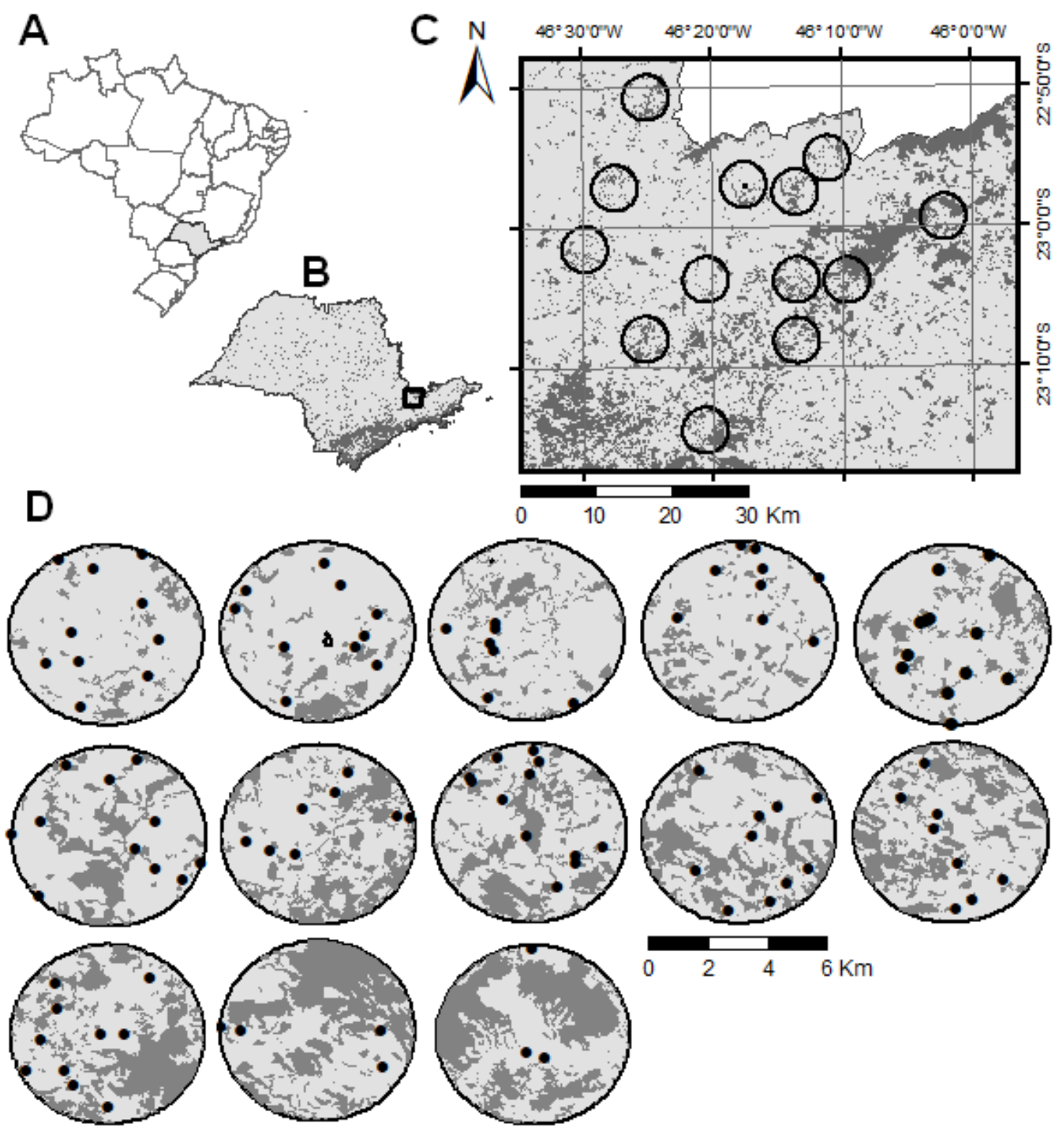

Figure 2. Study area. A) Map of Brazil, highlighting the State of São Paulo; B) Remaining Atlantic forest (darker grey) and the location of the study area in the State of São Paulo; C) Location of the 13 landscapes within the study area; D) Remaining forest cover (darker grey) and spatial distribution of participants' households (points) in each landscape. Landscapes are ordered from minimum to maximum forest cover.

\section{Sampling design}

We used a hierarchical sampling design, firstly selecting landscapes within the study area and then properties and interviewees within landscapes. We selected 13 landscapes with a $3 \mathrm{~km}$ radius (2826 ha) and a variable proportion of native forest cover - from 10 to $50 \%$, controlling for potential confounding factors (Pasher et al., 2013). The landscapes were 
constrained to 800 and 1300 m.a.s.l, on ferric red latosol or argisol soil; major highways, urban centers and water reservoirs were avoided. Land use in each landscape was mapped using high-resolution images (ArcGis 10.3 basemap imagery, DigitalGlobe satellites 20102011; scale of 1:5000).

Within each of the 13 landscapes, we selected properties among those registered in the Environmental Rural Register (Cadastro Ambiental Rural - CAR), a database maintained by the government of the State of São Paulo, mandatory for owners of rural properties destined to farming activities (INCRA, 2010). Among those properties declared in CAR, we excluded those with no house (checked by satellite images) or with houses located outside the study landscapes and those that overlapped more than one landscape. For the remaining properties, we calculated the amount of native forest within their limits. First, we visited all 301 properties with more than 1 ha of native forest aiming at increasing the chance of including interviewees that had experiences with wildlife (Appendix A) to check if the characteristics of the property and the owner met our criteria for inclusion in the study (see below), and conduct the interviews when appropriate. In a second phase, we strategically chose 50 properties, among the properties with less than 1 ha of native forest (Appendix A), located in areas with few or no interviews to minimize difference in sample size across landscapes and maximize the spatial coverage of each landscape, and visited them to check if the characteristics of the property and the owner met our criteria for inclusion (see below).

From March to August 2017, all 351 properties were visited to verify if the owners raised livestock in the property (to guarantee the possibility of attacks from native mammals), if the owner and self-declared responsible for livestock management, man or woman, was older than 18 years old and resided in the property (Appendix A). If so, the landowner was invited to participate in the study. The final sample was composed of 114 interviewees (Figure 2D). 


\section{Data collection}

Ecological context: To represent the ecological context, we calculated native forest cover surrounding the household of each participant. Given the difference in body size across target species, forest cover was calculated considering four radii: $0.5,1.0,1.5$ and $2.0 \mathrm{~km}$. The proportion of forest cover varied from $0 \%$ to $56 \%, 0.5 \%$ to $54 \%, 2 \%$ to $52 \%$, and $4 \%$ to $51 \%$ at the $0.5,1,1.5$ and $2 \mathrm{~km}$ scales, respectively, and forest cover was correlated across scales ( $\mathrm{r}$ $>0.4, \mathrm{p}<0.0001)$

Using a structured questionnaire previously tested in a pilot study (Appendix B), we carried out face-to-face interviews with the 114 participants to assess:

Socio-demographic variables and livestock raised in the property: We asked interviewees their sex, age, education level (completed years of formal school education), main activity (urban or rural), place of birth, types of livestock raised in the property and dependence on livestock. The latter was measured using a four-item index based on (Dickman, 2008), ranging from 1 to 11 (Appendix $\mathrm{C}$ ).

Identification of the target species: Interviewees were asked to identify the target species from plates with pictures of wild mammals that occur in the region, including some similar to the target species (Appendix D). The questionnaire was then applied to all interviewees who were able to identify at least one of the three target species, but only questions regarding the properly identified species were asked.

Experiences with the target species: Both contact with the species and attacks to livestock caused by the species were measured as frequencies (within the last 6 months, 12 months, and 5 years, for the opossum, the crab-eating fox or the puma, respectively; Appendix E). However, as both events (contact and attacks) were relatively rare for all target species, we used both as binary variables. The interviewee was considered to have had contact with the 
species if he/she either saw the species in the field, and/or heard at least one report from family and friends about the species. Similarly, the interviewee was considered to have suffered attacks to his/her livestock if at least one attack to any type of livestock by the target species occurred in the property.

Emotions and beliefs towards target species: Among the different ways to measure emotions towards wildlife (cf. Jacobs et al., 2012), we chose the self-report method using a discrete perspective, i.e., asking people how they believe seeing or thinking about the species make them feel, using words they frequently employ in daily language, such as "joy" and "fear" (Jacobs et al., 2014). Most common emotions towards the target species were elicited in the pilot study (Appendix B). Fear, disgust, joy and interest were the four most frequently mentioned and were included in the study by asking interviewees how strongly they believe they feel each of them in two different contexts: when thinking of the species and when encountering the species in the field (Appendix F). We then grouped emotions with similar valence (positive or negative), i.e., fear together with disgust, and joy together with interest, and for each group we summed the values for the items representing different contexts (thinking and encountering) as they were highly correlated, resulting in two indices with four items each, one for positive and one for negative emotions.

Beliefs towards wildlife can greatly vary depending on the social context, and were elicited in the population of the study region in a pilot study (Appendix B). People mentioned six beliefs related to benefits brought about by the opossum and the crab-eating fox, from which five were also mentioned for the puma, and the same four beliefs related to risks brought about by the three species (Appendix F). Using the expectancy-value mode (Fishbein \& Ajzen, 2011), the index of positive beliefs (perception of benefits) was calculated as the sum of the products between the strength (i.e., the subjective probability that the species will undoubtedly bring about that benefit) and the evaluation (i.e., how important to the person the 
benefit is) across all six items for the opossum and crab-eating fox and all five items for the puma (Appendix F). Similarly, negative beliefs were measured summing, across all four items (Appendix F), the products between the cognitive (i.e., perceived likelihood of specific negative human-wildlife interactions) and affective (i.e., dread or worry felt towards specific negative human-wildlife interactions) components of risk perception (Carter et al., 2012; Bruskotter \& Wilson, 2014). For both emotions and beliefs, responses to each item used to compute the final index were given using a visual unidirectional scale with seven categories (Appendix G).

Attitude and tolerance towards target species: We measured attitude using a semantic differential scale (Osgood et al., 1978) with five pairs of adjectives concerning the target species to quantify how favorable a person is towards the species, each pair representing an item (Appendix F). Interviewees responded each item using a visual bidirectional scale with seven categories (from -3 to +3 , Appendix G), and the attitude scale was calculated as the sum of all values across the five items. Attitude scales for all target species were reliable and measured only one construct (Appendix H). We assessed tolerance using the Wildlife Acceptance Capacity (WAC) or wildlife stakeholder acceptance capacity (WSAC), proposed by (Decker \& Purdy, 1988), which reflects the "maximum wildlife population in an area that is acceptable to people". We computed WAC index summing the values of two items (Appendix F): how small or big the respondent would like the size of the population of the target species to be considering two different spatial scales: (1) in their region and (2) in the State of São Paulo, both using a 7-point bidirectional scale (from -3 to 3, Appendix G).

Prior to the interviews, participants received a summary folder explaining the research and a consent term. Questionnaires were applied by two researchers (KCTD and LT), who were together during the first 30 interviews to standardize the way of talking and acting, minimizing interviewer bias. The research and the questionnaire were approved by the 
Research Ethics Committee from the Brazilian National Commission for Research Ethics (CAAE $n^{\circ}$ 61660916.3.0000.5464). The original, complete version of the questionnaire in Portuguese in presented in Appendix I.

\section{Data analyses}

We used Piecewise Structural Equation Modeling (Piecewise SEM; Lefcheck, 2016a) to evaluate the proposed conceptual model (Figure 1). This method requires smaller sample size compared to traditional SEM, allows the inclusion of mixed-effects, necessary given the hierarchical nature of the sampling design (participants grouped within landscapes), as well as the use of appropriate probability distributions for different variables. In Piecewise SEM, the data is compared to the hypothesized model using an alternative to chi-square test for goodness-of-fit, namely Fisher's $\mathrm{C}$ test. A p-value $\leq 0.05$ indicates deviations between data and the model and a poor fit of the model to the data. In this case, it is possible to re-specify the model by including significant missing paths indicated by the analysis. Akaike's Information Criterion (AIC) or AIC corrected for small samples (AICc) can be computed from Fisher's C statistic for comparing models with the same dependent variables.

For each target species, we investigated which distribution best fitted each of the dependent variables in the models (Appendix $\mathbf{J}$ ), tested the collinearity among independent variables (Appendix J) and then used the Piecewise SEM package (Lefcheck, 2016b) in R environment ( $\mathrm{R}$ Core Team, 2016) to implement the analyses. The 13 study landscapes entered the analysis as a random variable. For each species, we run the model proposed in Figure 1 four times, each using a different measure of the ecological context (four spatial scales - proportion of native forest cover within $0.5,1,1.5$ and $2 \mathrm{~km}$ around the households), and assessed model fit. If fit was poor, we included the significant missing paths indicated by the analysis and that were conceptually plausible, one by one (beginning with the most significant), until the model had a good fit to the data (Appendix K). We then evaluated which 
were the significant paths in each model. Because all variables in all models varied (or were transformed to vary) from 0 to 1 (Appendix $\mathbf{J}$ ), coefficients can be compared across variables. We also compared the models with the four ecological context variables through AICc, interpreting equally plausible models when $\triangle \mathrm{AIC} \leq 2$ (Burnham \& Anderson, 2002).

\section{RESULTS}

\section{Characterization of the sampled population}

Among the 114 interviewees, $87(76 \%)$ were male, and most (71\%) were born in the region. Age of participants varied from 23 to 82 years old, with $43 \%$ older than 60 years old. The average years of formal education was $6.5( \pm 5.2)$, but most $(58 \%)$ had less than 4 years of formal education. Farming was the main activity for $89 \%$ of participants, and poultry $(88 \%)$ and cattle (74\%) were the most frequent, and sheep (8\%) the least frequent, livestock across properties. Participants' dependence on livestock was, on average, moderate $(6.15 \pm$ 1.86): most participants (77\%) had their livestock in one property; for $45 \%$ of the participants, their livestock was the main source of meat consumed at their households, and $72 \%$ of participants reported using livestock as main source of milk and eggs; finally, products from livestock such as meat, milk and eggs represented more than half of the income for $46 \%$ of the participants.

The opossum was not only the species that attacked livestock (mainly chicks and egg) in a higher proportion of properties, but also the species encountered by a higher proportion of interviewees, followed by the crab-eating fox and the puma (Table 1). The puma was, however, the species from which a higher proportion of interviewees heard from other people (Table 1). 
Table 1: Experiences interviewees had with the target species: opossum (Didelphis aurita), crab-eating fox (Cerdocyon thous) and puma (Puma concolor). $\mathrm{N}=$ number of interviewees who identified the species; Time $=$ time interval interviewees were asked if they had contact with the target species or had their livestock attached by them; Damage $=$ number of interviewees whose livestock was attacked by the target species; Encounter $=$ number of interviewees who encountered the species; Report $=$ number of interviewees who heard reports from local people about the species; Contact $=$ number of interviewees who either encountered the species and/or heard reports from local people about the species.

\begin{tabular}{lcccccc}
\hline Species & N & $\begin{array}{c}\text { Time } \\
\text { (months) }\end{array}$ & Damage & Encounter & Report & Contact \\
\hline Opossum & 112 & 6 & 34 & 72 & 34 & 78 \\
& & & $(30 \%)$ & $(64 \%)$ & $(30 \%)$ & $(70 \%)$ \\
Crab-eating fox & 103 & 12 & 19 & 44 & 43 & 61 \\
& & & $(18 \%)$ & $(43 \%)$ & $(42 \%)$ & $(59 \%)$ \\
Puma & 102 & 60 & 9 & 16 & 62 & 67 \\
& & & $(6 \%)$ & $(16 \%)$ & $(61 \%)$ & $(66 \%)$ \\
\hline
\end{tabular}

For all target species, positive emotions (joy and interest) achieved higher values, on average across interviewees, than negative emotions (fear and disgust) (Table 2). However, across target species, a higher average value for negative emotions was observed for the puma. Similarly, although negative beliefs (risk perception) varied widely, average values were lower than those for positive beliefs (perception of benefits) for all target species (Table 2). On average, interviewees had neutral to favorable attitudes towards the three species, and they were slightly more tolerant than intolerant towards them (Table 2). 
Table 2: Mean, standard deviation, median, minimum and maximum values observed for emotions, beliefs, attitude and tolerance towards the target species: opossum (Didelphis aurita), crab-eating fox (Cerdocyon thous) and puma (Puma concolor).

\begin{tabular}{|c|c|c|c|c|c|}
\hline Variable & Species & Mean \pm SD & Median & $\operatorname{Min}^{b}$ & $\operatorname{Max}^{b}$ \\
\hline \multirow{3}{*}{ Positive emotions } & Opossum & $13.1 \pm 8.2$ & 11 & 4 & 28 \\
\hline & Crab-eating Fox & $15.0 \pm 8.0$ & 16 & 4 & 28 \\
\hline & Puma & $15.7 \pm 8.8$ & 16 & 4 & 28 \\
\hline \multirow{3}{*}{ Negative emotions } & Opossum & $6.8 \pm 4.6$ & 4 & 4 & 21 \\
\hline & Crab-eating Fox & $6.2 \pm 3.7$ & 4 & 4 & 16 \\
\hline & Puma & $10.6 \pm 4.5$ & 10 & 4 & 28 \\
\hline \multirow{3}{*}{ Positive beliefs ${ }^{\text {a }}$} & Opossum & $26.1 \pm 9.9$ & 27.3 & 2.3 & 45.6 \\
\hline & Crab-eating Fox & $28.3 \pm 10.4$ & 28.8 & 2.7 & 46.7 \\
\hline & Puma & $31.2 \pm 11.5$ & 26.8 & 3 & 49 \\
\hline \multirow{3}{*}{ Negative beliefs ${ }^{a}$} & Opossum & $4.1 \pm 5.2$ & 1.8 & 1 & 31.3 \\
\hline & Crab-eating Fox & $4.4 \pm 5.6$ & 2.3 & 1 & 31 \\
\hline & Puma & $6.5 \pm 7.0$ & 2.6 & 1 & 33.5 \\
\hline \multirow{3}{*}{ Attitude } & Opossum & $0.3 \pm 6.8$ & 0 & -15 & 15 \\
\hline & Crab-eating fox & $3.3 \pm 6.2$ & 3 & -15 & 15 \\
\hline & Puma & $3.6 \pm 7.0$ & 4 & -15 & 15 \\
\hline \multirow{3}{*}{ Tolerance } & Opossum & $0.5 \pm 2.5$ & 0 & -6 & 6 \\
\hline & Crab-eating fox & $0.1 \pm 2.5$ & 1 & -6 & 6 \\
\hline & Puma & $0.4 \pm 3.2$ & 0.5 & -6 & 6 \\
\hline
\end{tabular}

\footnotetext{
${ }^{a}$ The values of the indices for positive and negative beliefs were divided by the number of items to allow comparison between the variables.

${ }^{\mathrm{b}}$ Scale extremes: Emotions: 4 to 28 ; Negative and positive beliefs: 1 to 49 , Attitude: -15 to 15, Tolerance: -6 to 6 .
}

\section{Piecewise Structural Equation Modeling}

Based on the Fisher's C statistic, the proposed conceptual model of how the ecological context, i.e., forest cover, affects tolerance (Figure 1) presented low fit for all target species, considering all four spatial scales (Fisher's $\mathrm{C}>85, \mathrm{p}<0.05$ ). However, after re-specifying the models by including the conceptually plausible, most significant missing paths suggested by the analysis (Appendix K; Figure 3), the models presented a good fit for all species, regardless of the variable of ecological context considered (Table 3). For the opossum, the models 
considering the ecological context (i.e. forest cover) at 1 and $1.5 \mathrm{~km}$ around households were equally plausible, whereas for both the crab-eating fox and the puma, those considering the ecological context in 1, 1.5 and $2 \mathrm{~km}$ around households were equally plausible (Table 3 ).

Table 3: Results of the Piecewise SEM analyses for the final conceptual models on how the ecological context affects tolerance towards the opossum (Didelphis aurita), the crab-eating fox (Cerdocyon thous) and the puma (Puma concolor $)$. Ecological context $=$ spatial scale at which the proportion of native forest cover around participants' households was computed; Fishers's $\mathrm{C}=$ Fischer's $\mathrm{C}$ statistic of the model; DF = degrees of freedom; Akaike's Information Criterion corrected for small samples (AICc); $\triangle \mathrm{AICc}=$ Difference between AICc values of each model in relation to the model with the lowest $\mathrm{AICc}$ value; $\mathrm{K}=$ Likelihood degrees of freedom. Equally plausible models $(\triangle \mathrm{AICc}<2)$ are shadowed in grey.

\begin{tabular}{lccccccc}
\hline Model & $\begin{array}{c}\text { Ecological } \\
\text { Context }\end{array}$ & Fisher's C & DF & p-value & AICc & $\Delta$ AICc & K \\
\hline \multirow{3}{*}{ Opossum } & $0.5 \mathrm{~km}$ & 53.06 & 38 & 0.053 & 174.39 & 3.16 & 39 \\
& $1 \mathrm{~km}$ & 50.31 & 38 & 0.087 & 171.64 & 0.41 & 39 \\
& $1.5 \mathrm{~km}$ & 49.90 & 38 & 0.094 & 171.23 & 0.00 & 39 \\
\hline \multirow{3}{*}{ Crab-eating } & $2 \mathrm{~km}$ & 52.53 & 38 & 0.059 & 173.86 & 2.63 & 39 \\
\hline fox & $0.5 \mathrm{~km}$ & 45.67 & 36 & 0.130 & 178.57 & 5.45 & 40 \\
& $1 \mathrm{~km}$ & 40.22 & 36 & 0.289 & 173.12 & 0.00 & 40 \\
& $1.5 \mathrm{~km}$ & 40.44 & 36 & 0.281 & 173.34 & 0.22 & 40 \\
Puma & $2 \mathrm{~km}$ & 40.83 & 36 & 0.266 & 173.73 & 0.61 & 40 \\
\hline & $0.5 \mathrm{~km}$ & 42.04 & 38 & 0.300 & 170.36 & 2.87 & 39 \\
& $1 \mathrm{~km}$ & 40.13 & 38 & 0.376 & 168.45 & 0.96 & 39 \\
& $1.5 \mathrm{~km}$ & 39.25 & 38 & 0.414 & 167.57 & 0.08 & 39 \\
& $2 \mathrm{~km}$ & 39.17 & 38 & 0.417 & 167.49 & 0.00 & 39 \\
\hline
\end{tabular}

Ecological context, i.e., forest cover, had a significant effect on experiences only for the largest species - the puma - and just at larger spatial scales (Figure 3). In this case, forest cover had a strong, positive effect on damage caused by attacks to livestock (but no effect on contact), having thus an indirect negative effect on attitude and tolerance towards the puma (Figure 3).

Comparing the impact of experiences with wildlife across species (Figure 3), contact had a positive effect on attitude and tolerance towards the opossum and puma, due to its positive effect on positive beliefs, whereas contact had a positive effect on negative beliefs 
towards the crab-eating fox, negatively affecting attitude and tolerance towards this species. Similarly, the effect of damage caused by attacks to livestock varied across species. Damage did not significantly affect emotions nor beliefs towards the opossum, but had positive effect on negative beliefs towards the crab-eating fox and the puma, and a positive effect on negative emotions towards the puma, thus negatively affecting attitude and tolerance towards these species.

Positive beliefs had a positive effect, while negative beliefs had a negative effect on attitude towards all target species (Figure 3). However, while positive emotions had a positive effect on attitude towards all target species, negative emotions had a significant, negative effect only on attitude towards the puma. Finally, the relation between attitude and tolerance was positive and significant across all target species (Figure 3).

All significant missing paths included in the re-specified models are associated with emotions and beliefs (Appendix K; Figure 3). While the positive relationship between positive beliefs and emotions was significant for all target species, the positive relationship between negative beliefs and emotions was significant only for the crab-eating fox and the puma. Lastly, the negative relationship between negative emotions and positive emotions was significant only for the opossum. 

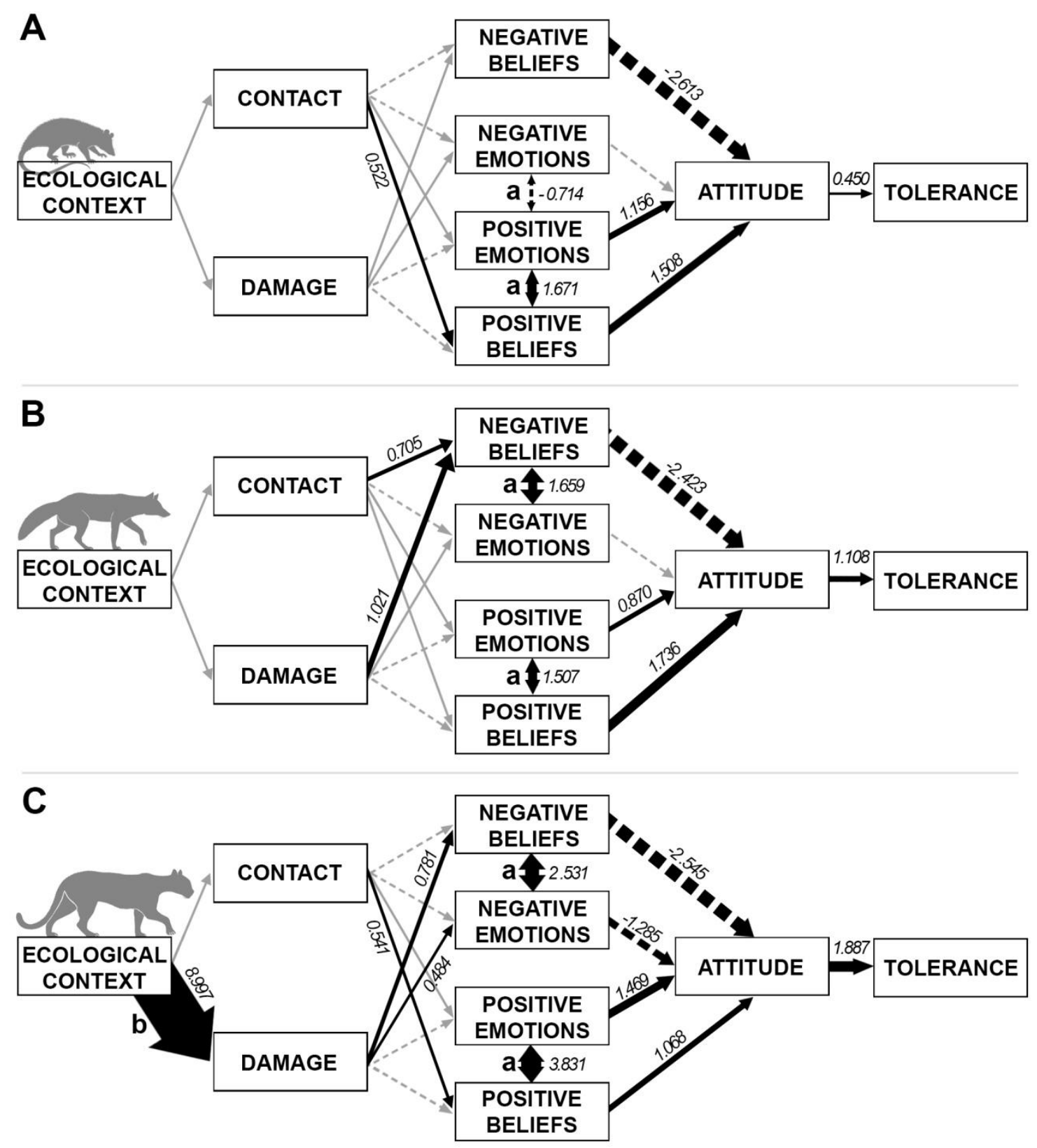

Figure 3: Final models of how the ecological context affects tolerance towards the A) opossum (Didelphis aurita), B) crab-eating fox (Cerdocyon thous) and C) puma (Puma concolor). Arrows indicate causal links between variables (rectangles). Black, continuous arrows indicate significant, positive effects, and black, dashed arrows indicate significant, negative effects. Grey arrows indicate non-significant effects. Thicknesses of arrows represent relative differences in the effects of variables, based on coefficients (shown over the arrows; coefficients are comparable because all variables ranged from 0 to 1 ). Ecological context $=$ proportion of native forest cover around households; Contact $=$ contact with the species; Damage $=$ attacks to livestock caused by the species; Negative and positive beliefs = perception of risks and benefits associated with the species, respectively. Positive and negative emotions $=$ emotions people believe wildlife will bring them, with positive and negative valence, respectively. Attitude $=$ attitude towards the species; Tolerance $=$ tolerance towards the species; $\mathrm{a}=$ conceptually plausible paths indicated as missing from the initial model (Figure 1), and for which we did not assume direction of effect because SEM does not allow assumption of directionality for missing paths when fitting models via a link function to a non-normal distribution (Piecewise SEM, 2018); $b=$ causal path that was significant only when considering the ecological context at larger spatial scales. 


\section{DISCUSSION}

By taking an interdisciplinary approach, our study highlights that the ecological context where people live can be relevant to determine experiences, attitude and tolerance towards wildlife. However, the effect of the ecological context varied across species, being significant for larger species at larger spatial scales, negatively affecting attitude and tolerance towards the puma, but not the crab-eating fox or opossum. For all wildlife species, experiences, either contact with species and/or damage from attacks to livestock, did influence emotions and/or beliefs, shaping the attitude and tolerance towards wildlife. Yet, the relevant pathways through which experiences shape attitude and tolerance vary across species, indicating the critical role of studies such as ours to inform specific, context-effective strategies to mitigate human-wildlife conflicts. In the next sections, we first compare the pathways through which the ecological context affects tolerance across different species. Then we discuss how our results can contribute to studies of human-wildlife conflicts in general, and end up by suggesting implications for managing and mitigating human-wildlife conflicts.

\section{Pathways connecting ecological context and tolerance - comparisons across species}

Remaining native forest at the landscape was important for defining the experiences people had with wild mammals only for the largest species - the puma, which is the species demanding the largest areas and is the least tolerant to habitat loss among the studied species (Bogoni et al., 2016; Regolin et al., 2017). Indeed, previous studies have shown that forest cover is a key determinant of attacks to livestock by larger felids in Central and South America (Michalski et al., 2006; Azevedo \& Murray, 2007; Soto-Shoender \& Giuliano, 2011). Smaller species, however, have been neglected in HWC studies (Peterson et al., 2010) and the few studies considering medium-sized mammals refer mostly to African canids (e.g., Gusset et al., 2009; Lyamuya et al., 2014), but they investigated aspects other than the 
ecological drivers of conflicts. Our results thus suggest that the ecological context is less important in determining attacks and conflicts with medium-sized mammals, as these species tend to be more homogeneously distributed across landscapes with different amounts of remaining original habitat.

Our study is also novel in comparing how the ecological context influences different experiences with wildlife, not only attacks to livestock but also the contact or encounters people have with wild species. Some studies suggest that encounters with wildlife are more likely to happen in more vegetated, isolated areas (Llaneza et al., 2016; Kshettry et al., 2017). Indeed, habitat amount is known to increase not only the abundance (Fahrig, 2003), but also the movements of animals (Tucker et al., 2018), so we expected that people living in more forested landscapes would have more contact with mammals. Yet, our results did not corroborate this hypothesis for any of the studied species. We suggest that this maybe the result of smaller species, such as the crab-eating fox and opossum, not being strongly affected by habitat loss (Bogoni et al., 2016; Regolin et al., 2017), whereas larger species, such as the puma, although being more common and/or ranging widely or more frequently in more forested landscapes, are relatively rare and secretive. Especially in densely populated areas as the Atlantic forest, mammals probably avoid humans, a behavior already known for larger mammals (Rogala et al., 2011), making encounters with wildlife decoupled from abundance or range/ frequency of movements. In any case, our results suggest that encountering wildlife may not be strongly determined by habitat cover remaining at the landscape, at least in densely occupied areas.

Irrespective of being determined by the ecological context, our study highlights that both experiences with wildlife - attacks to livestock and contact with wildlife - are indeed relevant to shape the antecedents of human behavior towards wildlife. However, the relevance and the effects of these experiences varied across species. Attacks to livestock caused by the 
puma fostered both negative beliefs (perception of risks) and negative emotions towards this species, while attacks from the crab-eating fox promoted only negative beliefs (perception of risks), and attacks were irrelevant in driving either beliefs or emotions towards the opossum. These results are congruent with the fact that larger species are more likely to frighten people and cause greater economic losses due to attacks to larger, more valuable livestock (Dickman et al., 2014) compared to smaller species (Patterson et al., 2004). Indeed, the compilation of previous studies through a meta-analysis (Kansky et al., 2014) showed that the effects of livestock depredation on beliefs or attitude towards wildlife vary across species. By including different wildlife species while controlling social and ecological contexts, our findings suggest that the variable effects of damage to livestock on attitude and tolerance towards wildlife may be driven by the size of the species, and be mediated not only by beliefs but also emotions.

In contrast, contact with wildlife affected only beliefs, but with very distinct effects: having contact with the species promoted positive beliefs (perception of benefits) towards the opossum and the puma, but instead fostered negative beliefs (perception of risks) towards the crab-eating fox. Environmental education initiatives have shown that direct contact with animals leads to more favorable attitude towards wildlife (Dettmann-Easler \& Pease, 1999; Burnett et al., 2016). More generally, a large body of evidence suggests that experiences with non-human nature increases pro-conservation behaviors (Zaradic et al., 2009; Zhang et al., 2014). However, unexpected encounters with wildlife can enhance negative beliefs towards wildlife (Elliot et al., 2016). The observed variable effects of contact - that are not related to body size across species - indicate that factors, other than how common or dangerous a species is, mediate the effects of encountering wildlife. This may be particularly relevant when considering unexpected encounters in rural areas, as opposed to premeditated, oriented encounters during educational activities. Indeed, encounters may themselves be either positive 
or negative, leading to opposing effects on tolerance towards wildlife as argued by Jochum et al. (2014). Future studies should try to quantify different types of contact with wildlife to help understanding how direct experiences such as observing wildlife may shape human behavior.

Lastly, we aimed at identifying the most relevant proximate drivers of attitude and tolerance towards wildlife, among negative and positive beliefs and emotions. We observed that all of them were important for all species, excepting negative emotions, which determined attitude only in the largest species - the puma. Many studies have already highlighted the importance of negative emotions in shaping attitude towards larger mammals (Røskaft et al., 2007; Marseille et al., 2012; Jacobs et al., 2014), especially fear (Jacobs, 2012; Johansson et al., 2016). However, besides not including all of these four antecedents of attitude simultaneously, previous empirical studies focused mostly on single, or similar-sized, large carnivores (Carter et al., 2012; Zajac et al., 2012; Treves et al., 2013; Elliot et al., 2016; Inskip et al., 2016; but see Røskaft et al., 2007). Hence, our results suggest the importance of considering different types of beliefs and emotions in shaping attitude and tolerance towards wildlife, and bring empirical evidence that negative emotions are indeed most relevant for larger species.

\section{Contributions to the study of human-wildlife conflicts}

Given the importance of managing conflicts for both human livelihoods and wildlife conservation, research on HWC have grown considerably in the last decades. On the one hand, an extensive literature approached the importance of the ecological context to experiences with wildlife (Kissui, 2008; Goswami et al., 2015; Miller, 2015), and on the other hand, human dimensions such as beliefs, emotions, attitude and tolerance have been studied in the context of conflicts (Bruskotter \& Wilson, 2014; Inskip et al., 2014; Kansky \& Knight, 2014). Our conceptual model tries to bring these two approaches together, causally structuring 
different components of human-wildlife interactions. Below, we discuss three contributions our model can bring to the understanding of HWC.

First, the literature on human-wildlife conflicts suggests that intangible costs (i.e., perception of risk or negative emotions) are more important in predicting attitude and tolerance than tangible costs (i.e., attacks by wildlife) (Kansky \& Knight, 2014). However, our study reveals that these two types of costs are actually causally structured, with ecological context predicting tangible costs, and those predicting intangible costs, which in turn affect attitude and tolerance. Although several studies have proposed conceptual models to understand the complexity of HWCs (Dickman et al., 2011; Carter et al., 2012; Bruskotter \& Wilson, 2014; Engel et al., 2016), they normally focused on human and/or ecological components of conflicts apart. Our results reinforce the need to conceptually and causally organize the different ecological and human components to understand human-wildlife conflicts.

Second, despite some studies have considered emotions separately from beliefs as we did (Vaske et al., 2013; Engel et al., 2016; Amit \& Jacobson, 2017), emotions have been traditionally merged into beliefs, focusing mostly on emotions with negative valence, such as fear (Johansson et al., 2016). Indeed, several authors have argued for the separation between positive and negative beliefs (Carter et al., 2012; Bruskotter \& Wilson, 2014; Inskip et al., 2016) and the importance of emotions other than fear to shape attitude and tolerance (Vaske et al., 2013; Jacobs et al., 2014). However, to best of our knowledge, there are no studies considering all these four antecedents of attitude simultaneously. Although emotions and beliefs are statistically correlated (as indicated by the missing paths in our analyses) and conceptually related (emotions as commonly measured in HWC literature are indeed beliefs about feelings), our results reinforce the relevance of separately considering positive and negative beliefs and emotions to better understand human dimensions of conflicts. This is 
because, as we showed here, beliefs and emotions may be affected by different experiences with wildlife and their effect on attitude and tolerance may vary across species (e.g., only for the puma, negative emotions were relevant). Moreover, considering both emotions and beliefs increases the quality of models (Sandberg \& Conner, 2008).

Lastly, in the HWC literature it is common to see the concepts of attitude and tolerance used either individually or as analogous concepts. The misunderstandings resulting from such approach has already been raised by other authors (Bruskotter \& Fulton, 2012; Bruskotter et al., 2015; Frank, 2016). Our study provides evidence that tolerance, as measured by the wildlife acceptance capacity (WAC; Decker \& Purdy, 1988), is indeed predicted by attitude across different species, corroborating the attitudinal gradient of tolerance discussed by Frank (2016). Such understanding can facilitate the organization of the results found in the HWC literature.

In short, our results provide evidence for the causal relationships between different ecological and human components of conflicts. The ecological context defines experiences with wildlife, which, as background factors, affect both beliefs and emotions; the latter understood as a belief regarding the emotion in question. In turn, beliefs and emotions are predictors of attitude and tolerance towards wildlife. Such causal structure is congruent with some psychological frameworks, such as the theory of planned behavior (TPB; Fishbein \& Ajzen, 2011), and may be useful to help unraveling and organizing the complexity of concepts within HWC research.

\section{Conservation implications}

Our results suggest that human-wildlife conflicts can be more intense in more forested landscapes, specially for larger species, less tolerant to habitat loss, which also tend to cause losses to landowners of more economic impact. Given this positive relationship, livestock depredation by wildlife can be viewed as an ecosystem disservice provided by forests 
(Dorresteijn et al., 2017). Despite the growth and progress of the ecosystem service approach to conservation (MEA, 2005; Dickson et al., 2014; Li \& Fang, 2014), only few, recent studies attempted to consider the importance of both services and disservices (Schaubroeck, 2017; Vaz et al., 2017; Campagne et al., 2018). We argue that human-wildlife conflicts should be studied and managed within a broader perspective, one that considers how these disservices can be counteracted by ecosystem services in shaping human attitude and behavior. TisovecDufner (2018) showed in the same study region, for instance, that ecosystem services provided by forests are more valued, and are more relevant to define the intention to preserve forests, than disservices associated with attacks to livestock. In this sense, understanding the potential contagious effect between beliefs, emotions and attitude towards different species (Dickman et al., 2014), and between them and whole ecosystem, seems a promising approach.

Our findings also suggest that strategies for mitigating HWC should consider a broader range of experiences with wildlife, not only wildlife attacks, but also potentially positive experiences, such as contact and encounters with wildlife (which had a positive influence on tolerance towards two of the studied species). Oriented contact with animals may enhance positive attitudes towards wildlife (Burnett et al., 2016; Sponarski et al., 2016), and can increase knowledge about the species (Lescureux et al., 2011), positively affecting attitudes towards wildlife (Piédallu et al., 2016). However, both contact (Elliot et al., 2016) and knowledge (Lescureux \& Linnell, 2010; Liu et al., 2011) may have negative effects on attitude towards wildlife. This is because encounters can be either positive or negative (Jochum et al., 2014), and specific knowledge, about benefits provided by wildlife, seems to be more relevant than general ecological knowledge in promoting favorable attitudes towards wildlife (Treves et al., 2004). Hence, strategies to mitigate HWC could be improved by focusing, not only on negative experiences such wildlife attacks, but also on oriented experiences with wildlife, especially those that strengthens beliefs about benefits of wildlife. 
Changing human attitude and tolerance, however, is not an easy task (Heberlein, 2012). By thinking on how to change systems, Meadows (1999) proposed twelve leverage points to intervene in a system, which vary in effectiveness: ranging from 'shallow' points, where interventions are easier to implement but bring little change, to 'deep' leverage points, resulting in greater transformation, but that are more difficult to be altered. According to Abson et al. (2017), a combination of interventions on deeper and shallow leverage points is more effective to promote change. Today, many proposed solutions - and those most frequently applied - to HWC are based on technical fixes, such as translocation of problem individuals, financial compensation for livestock losses, lethal control of predators and livestock fencing (McManus et al., 2014; Eklund et al., 2017; Eeden et al., 2018), which focus on shallower leverage points. An explicit consideration of the causal structure between the ecological and human components of human-wildlife conflicts, as we did here, can help identifying deeper leverage points to be targeted, together with traditional measures, to more effectively mitigate human-wildlife conflicts. Examples of such deeper leverage points are farmers' social trust, stakeholder empowerment, co-existence learning and values shifting (Carter \& Linnell, 2016; Dorresteijn et al., 2016; Lute et al., 2016; Bergstrom, 2017).

Strategies combining deeper and shallower leverage points might be particularly relevant for dealing with conflicts with larger carnivores. Managing such conflicts may be more difficult because they are more severe (Inskip \& Zimmermann, 2009), as larger species cause greater economic losses to farmers (Dickman et al., 2014). Moreover, our results bring evidence supporting previous findings (e.g., Røskaft et al., 2007) that, among all the antecedents of attitude, negative emotions are most relevant to shape attitude and tolerance towards larger species. As the effects of negative emotions may complicate solutions to these conflicts, combining shallower and deeper leverage points may be key for successfully tackle these conflicts. 
To move forward, research on HWC should address how the multiple drivers of human-wildlife conflicts are interconnected. Conflicts should be understood as interactions between the ecological and human components of socioecological systems, taking into consideration from distinct spatial-ecological aspects of landscapes to the complex antecedents of human behavior within a solid, conceptual framework. We hope our study helps the field moving in this direction.

\section{CONCLUSIONS}

- The ecological context, particularly, forest cover, while not affecting the contact people have with wildlife (at least in densely populated areas) positively affected the damage caused by larger species, suggesting conflicts with such species are more severe in more forested landscapes. HWC might then be considered as an ecosystem disservice, and should be framed and managed within broader perspectives considering the relationships and trade-offs between ecosystem services and disservices.

- Attacks to livestock negatively affected attitude and tolerance towards the two larger species (although effects on emotions was observed only for the largest species, the puma). In contrast, the effects of contact with wildlife may be either positive or negative. Hence, studies on experiences with wildlife that counteract the negative effect of attacks to livestock are encouraged, and mitigation strategies should focus on experiences that strengthens positive emotions and beliefs about benefits of wildlife.

- Although positive and negative beliefs, and positive emotions, affected attitude and tolerance towards all studied species, negative emotions were relevant only for larger species, making mitigation strategies for conflicts involving such species more 
difficult. Especially for these conflicts, mitigation actions that consider not only traditional measures such as livestock fencing or financial compensation, but also interventions on deeper human aspects, such as shifts in beliefs and emotions, might be more effective.

- We provide empirical evidence that: i. attitude is an antecedent of tolerance; ii. tangible costs (i.e., damage) influence intangible costs (e.g., negative emotions and beliefs); iii. positive and negative emotions and beliefs are affected by different experiences with wildlife and their effects on attitude and tolerance towards wildlife varies across species. Such results highlight the importance to conceptually consider the causal structure between ecological and human components of human-wildlife conflicts. This would help organize and compare results in the HWC literature, as well as identify relevant leverage points to effectively mitigate conflicts in practice.

\section{REFERENCES}

Abson, D.J., Fischer, J., Leventon, J., Newig, J., Schomerus, T., Vilsmaier, U., von Wehrden, H., Abernethy, P., Ives, C.D., Jager, N.W. \& Lang, D.J. 2017. Leverage points for sustainability transformation. Ambio, 46, 30-39.

Ajzen, I. 1991. The Theory of Planned Behavior. Orgnizational behavior and human decision processes, 50, 179-211.

Ajzen, I. 2011. The Theory of Planned Behaviour: Reactions and reflections. Psychology \& Health, 26, 1113-1127.

Alexander, J., Chen, P., Damerell, P., Youkui, W., Hughes, J., Shi, K. \& Riordan, P. 2015. Human wildlife conflict involving large carnivores in Qilianshan, China and the minimal paw-print of snow leopards. Biological Conservation, 187, 1-9.

Amit, R. \& Jacobson, S.K. 2017. Understanding rancher coexistence with jaguars and pumas: a typology for conservation practice. Biodiversity and Conservation, 26, 1353-1374.

Azevedo, F. \& Murray, D.L. 2007. Evaluation of potential factors predisposing livestock to predation by jaguars. Journal of Wildlife Management, 71, 2379-2379. 
Behr, D.M., Ozgul, A. \& Cozzi, G. 2017. Combining human acceptance and habitat suitability in a unified socio-ecological suitability model: a case study of the wolf in Switzerland. Journal of Applied Ecology, 54, 1919-1929.

Bergstrom, B.J. 2017. Carnivore conservation: shifting the paradigm from control to coexistence. Journal of Mammalogy, 98, 1-6.

Bermúdez, S.E., Gottdenker, N., Krishnvajhala, A., Fox, A., Wilder, H.K., González, K., Smith, D., López, M., Perea, M., Rigg, C., Montilla, S., Calzada, J.E., Saldaña, A., Caballero, C.M. \& Lopez, J.E. 2017. Synanthropic mammals as potential hosts of tickborne pathogens in Panama. PLoS ONE, 12, e0169047.

Bogoni, J.A., Cherem, J.J., Hettwer Giehl, E.L., Oliveira-Santos, L.G., de Castilho, P.V., Picinatto Filho, V., Fantacini, F.M., Tortato, M.A., Luiz, M.R., Rizzaro, R. \& Graipel, M.E. 2016. Landscape features lead to shifts in communities of medium- to largebodied mammals in subtropical Atlantic Forest. Journal of Mammalogy, 97, 713-725.

Borges, J.A.R., Tauer, L.W. \& Lansink, A.G.J.M.O. 2016. Using the theory of planned behavior to identify key beliefs underlying Brazilian cattle farmers' intention to use improved natural grassland: A MIMIC modelling approach. Land Use Policy, 55, $193-$ 203.

Bruskotter, J.T. \& Fulton, D.C. 2012. Will hunters steward wolves? A comment on Treves and Martin. Society \& Natural Resources, 25, 97-102.

Bruskotter, J.T., Singh, A., Fulton, D.C. \& Slagle, K. 2015. Assessing tolerance for wildlife: clarifying relations between concepts and measures. Human Dimensions of Wildlife, 20, 255-270.

Bruskotter, J.T. \& Wilson, R.S. 2014. Determining where the wild things will be: Using psychological theory to find tolerance for large carnivores. Conservation Letters, 7, 158-165.

Burnett, E., Sills, E., Peterson, M.N. \& DePerno, C. 2016. Impacts of the conservation education program in Serra Malagueta Natural Park, Cape Verde. Environmental Education Research, 22, 538-550.

Burnham, K.P. \& Anderson, D.R. 2002. Model selection and multimodel inference: $a$ practical information-theoretic approach. Springer, New York.

Campagne, C.S., Roche, P.K. \& Salles, J.-M. 2018. Looking into Pandora's box: Ecosystem disservices assessment and correlations with ecosystem services. Ecosystem Services, 30, 126-136.

Carter, N.H. \& Linnell, J.D.C. 2016. Co-adaptation is key to coexisting with large carnivores. Trends in Ecology \& Evolution, 31, 575-578.

Carter, N.H., Shrestha, B.K., Karki, J.B., Man, N., Pradhan, B. \& Liu, J. 2012. Coexistence between wildlife and humans at fine spatial scales. Proceeding of the Royal Sociaty London Biological Sciences, 109, 15360-15365. 
Carter, N.H., Viña, A., Hull, V., McConnell, W.J., Axinn, W., Ghimire, D. \& Liu, J. 2014. Coupled human and natural systems approach to wildlife research and conservation. Ecology and Society, 19, 43.

CEPAGRI. 2018. A classificação climática de Koeppen para o Estado de São Paulo. Available at: http://www.cepagri.unicamp.br/outras-informacoes/clima-dosmunicipios-paulistas.html. Access in March 8th, 2018.

Conover, M.R. 2002. Resolving Human-Wildlife Conflicts: The science of wildlife damage management. CRC Press, Boca Florida.

Cullen, L., Bodmer, R.E. \& Valladares Pádua, C. 2000. Effects of hunting in habitat fragments of the Atlantic forests, Brazil. Biological Conservation, 95, 49-56.

de Angelo, C., Paviolo, A., Rode, D., Cullen, L., Sana, D., Abreu, K.C., Xavier da Silva, M., Bertrand, A.-S., Haag, T., Lima, F., Rinaldi, A.R., Fernàndez, S., Ramírez, F., VelÃ zquez, M., Corio, C., Hasson, E. \& Di Bitetti, M.S. 2011. Participatory networks for large-scale monitoring of large carnivores: pumas and jaguars of the Upper Paraná Atlantic Forest. Oryx, 45, 534-545.

Decker, D.J. \& Purdy, K.G. 1988. Toward a concept of Wildlife Acceptance Capacity in wildlife management. Wildlife Society Bulletin (1973-2006), 16, 53-57.

Dettmann-Easler, D. \& Pease, J.L. 1999. Evaluating the effectiveness of residential environmental education programs in fostering positive attitudes toward wildlife. The Journal of Environmental Education, 31, 33-39.

Dickman, A.J. 2008. Key determinants of conflict between people and wildlife, particularly large carnivores, around Ruaha National Park, Tanzania. Thesis (Doctor of Philosophy), University College London.

Dickman, A.J. 2010. Complexities of conflict: The importance of considering social factors for effectively resolving human-wildlife conflict. Animal Conservation, 13, 458-466.

Dickman, A.J., Hazzah, L., Carbone, C. \& Durant, S.M. 2014. Carnivores, culture and 'contagious conflict': Multiple factors influence perceived problems with carnivores in Tanzania's Ruaha landscape. Biological Conservation, 178, 19-27.

Dickman, A.J., Macdonald, E.a. \& Macdonald, D.W. 2011. A review of financial instruments to pay for predator conservation and encourage human-carnivore coexistence. Proceedings of the National Academy of Sciences of the United States of America, 108, 13937-13944.

Dickson, B., Blaney, R., Miles, L., Regan, E., van Soesbergen, A., Väänänen, E., Blyth, S., Harfoot, M., Martin, C.S., McOwen, C., Newbold, T. \& van Bochove, J. 2014. Towards a global map of natural capital: Key ecosystem assets. UNEP, Nairobi, Kenya. 
Dorresteijn, I., Milcu, A.I., Leventon, J., Hanspach, J. \& Fischer, J. 2016. Social factors mediating human-carnivore coexistence: Understanding thematic strands influencing coexistence in Central Romania. Ambio, 1-11.

Dorresteijn, I., Schultner, J., Collier, N.F., Hylander, K., Senbeta, F. \& Fischer, J. 2017. Disaggregating ecosystem services and disservices in the cultural landscapes of southwestern Ethiopia: a study of rural perceptions. Landscape Ecology, 32, 21512165 .

Eeden, L.M., Crowther, M.S., Dickman, C.R., Macdonald, D.W., Ripple, W.J., Ritchie, E.G. \& Newsome, T.M. 2018. Managing conflict between large carnivores and livestock. Conservation Biology, 32, 26-34.

Eklund, A., López-Bao, J.V., Tourani, M., Chapron, G. \& Frank, J. 2017. Limited evidence on the effectiveness of interventions to reduce livestock predation by large carnivores. Scientific Reports, 7, 2097.

Elliot, E.E., Vallance, S. \& Molles, L.E. 2016. Coexisting with coyotes (Canis latrans) in an urban environment. Urban Ecosystems, 19, 1335-1350.

Engel, M.T., Vaske, J.J., Bath, A.J. \& Marchini, S. 2016. Predicting acceptability of jaguars and pumas in the Atlantic forest, Brazil. Human Dimensions of Wildlife, 21, 427-444.

Espartosa, K.D., Pinotti, B.T. \& Pardini, R. 2011. Performance of camera trapping and track counts for surveying large mammals in rainforest remnants. Biodiversity and Conservation, 20, 2815-2829.

Fahrig, L. 2003. Effects of habitat fragmentation on biodiversity. Annual Review of Ecology, Evolution, and Systematics, 34, 487-515.

Fishbein, M. \& Ajzen, I. 2011. Predicting and changing behavior: The Reasoned Action Approach. Taylor \& Francis.

Frank, B. 2016. Human-wildlife conflicts and the need to include tolerance and coexistence: An introductory comment. Society \& Natural Resources, 29, 738-743.

Goswami, V.R., Medhi, K., Nichols, J.D. \& Oli, M.K. 2015. Mechanistic understanding of human-wildlife conflict through a novel application of dynamic occupancy models. Conservation Biology, 29, 1100-1110.

Gusset, M., Swarner, M.J., Mponwane, L., Keletile, K. \& McNutt, J.W. 2009. Humanwildlife conflict in northern Botswana: livestock predation by Endangered African wild dog Lycaon pictus and other carnivores. Oryx, 43, 67-72.

Heberlein, T.A. 2012. Navigating environmental attitudes. Conservation Biology, 26, 583585.

Horta, M.C., Labruna, M.B., Pinter, A., Linardi, P.M. \& Schumaker, T.T.S. 2007. Rickettsia infection in five areas of the State of São Paulo, Brazil. Memórias do Instituto Oswaldo Cruz, 102, 793-801.

Hunter, L. \& Barrett, P. 2011. Carnivores of the World. Princeton University Press, Princeton. 
IBGE. 2006. Censo agropecuário. Available at: https://www.ibge.gov.br/estatisticasnovoportal/economicas/agricultura-e-pecuaria/9827-censo-agropecuario.html?\&t=resu ltados. Access in February 28th, 2018.

IBGE. 2010. Censo demográfico. Available at: https://www.ibge.gov.br/estatisticasnovoportal/sociais/habitacao/9662-censo-demografico-2010.html?\&t=resultados. Access in February 28th, 2018.

IBGE. 2017. Estimativas de população. Available at: https://www.ibge.gov.br/estatisticasnovoportal/sociais/populacao/9103-estimativas-de-populacao.html?\&t=o-que-e. Access in February 28th, 2018.

INCRA. 2010. O que é Imóvel Rural nos termos da legislação agrária? Available at: http://www.incra.gov.br/o-que-e-imovel-rural-nos-termos-da-legislacao-agraria. Access in January 26th, 2018.

Inskip, C., Carter, N., Riley, S., Roberts, T. \& MacMillan, D. 2016. Toward human-carnivore coexistence: Understanding tolerance for tigers in Bangladesh. PLOS ONE, 11, e0145913.

Inskip, C., Fahad, Z., Tully, R., Roberts, T. \& MacMillan, D. 2014. Understanding carnivore killing behaviour: Exploring the motivations for tiger killing in the Sundarbans, Bangladesh. Biological Conservation, 180, 42-50.

Inskip, C. \& Zimmermann, A. 2009. Human-felid conflict: a review of patterns and priorities worldwide. Oryx, 43, 18-18.

Jacobs, M.H. 2012. Human emotions toward wildlife. Human Dimensions of Wildlife, 17, 1-3.

Jacobs, M.H., Fehres, P. \& Campbell, M. 2012. Measuring emotions toward wildlife: A review of generic methods and instruments. Human Dimensions of Wildlife, 17, 233247.

Jacobs, M.H., Vaske, J.J., Dubois, S. \& Fehres, P. 2014. More than fear: role of emotions in acceptability of lethal control of wolves. European Journal of Wildlife Research, 60, 589-598.

Jochum, K.A., Kliskey, A.A., Hundertmark, K.J. \& Alessa, L. 2014. Integrating complexity in the management of human-wildlife encounters. Global Environmental Change, 26, 73 86.

Johansson, M., Ferreira, I.A., Støen, O.-G., Frank, J. \& Flykt, A. 2016. Targeting human fear of large carnivores - Many ideas but few known effects. Biological Conservation, 201, 261-269.

Jorge, M.L.S.P., Galetti, M., Ribeiro, M.C. \& Ferraz, K.M.P.M.B. 2013. Mammal defaunation as surrogate of trophic cascades in a biodiversity hotspot. Biological Conservation, 163, 49-57. 
Kahler, J.S. \& Gore, M.L. 2014. Local perceptions of risk associated with poaching of wildlife implicated in human-wildlife conflicts in Namibia. Biological Conservation, $189,49-58$.

Kansky, R., Kidd, M. \& Knight, A.T. 2014. Meta-analysis of attitudes toward damagecausing mammalian wildlife. Conservation Biology, 28, 924-938.

Kansky, R., Kidd, M. \& Knight, A.T. 2016. A wildlife tolerance model and case study for understanding human wildlife conflicts. Biological Conservation, 201, 137-145.

Kansky, R. \& Knight, A.T. 2014. Key factors driving attitudes towards large mammals in conflict with humans. Biological Conservation, 179, 93-105.

Kinnaird, M.F., Sanderson, E.W., O'Brien, T.G., Wibisono, H.T. \& Woolmer, G. 2003. Deforestation trends in a tropical landscape and implications for endangered large mammals. Conservation Biology, 17, 245-257.

Kissui, B.M. 2008. Livestock predation by lions, leopards, spotted hyenas, and their vulnerability to retaliatory killing in the Maasai steppe, Tanzania. Animal Conservation, 11, 422-432.

Kshettry, A., Vaidyanathan, S. \& Athreya, V. 2017. Leopard in a tea-cup: A study of leopard habitat-use and human-leopard interactions in north-eastern India. PLoS ONE, 12, $\mathrm{e} 0177013$.

Leeuw, A., Valois, P., Ajzen, I. \& Schmidt, P. 2015. Using the theory of planned behavior to identify key beliefs underlying pro-environmental behavior in high-school students: Implications for educational interventions. Journal of Environmental Psychology, 42, 128-138.

Lefcheck, J.S. 2016a. PiecewiseSEM: Piecewise structural equation modelling in $\mathrm{R}$ for ecology, evolution, and systematics. Methods in Ecology and Evolution, 7, 573-579.

Lefcheck, J.S. 2016b. Piecewise Structural Equation Modeling (Version 1.2.1). Retrieved from https://CRAN.R-project.org/package=piecewiseSEM.

Lescureux, N. \& Linnell, J.D.C. 2010. Knowledge and perceptions of Macedonian hunters and herders: The influence of species specific ecology of bears, wolves, and lynx. Human Ecology, 38, 389-399.

Lescureux, N., Linnell, J.D.C., Mustafa, S., Melovski, D., Stojanov, A., Ivanov, G., Avukatov, V., von Arx, M. \& Breitenmoser, U. 2011. Fear of the unknown: local knowledge and perceptions of the Eurasian lynx Lynx lynx in western Macedonia. Oryx, 45, 600-607.

Li, C., Jiang, Z., Li, C., Tang, S., Li, F., Luo, Z., Ping, X., Liu, Z., Chen, J. \& Fang, H. 2015. Livestock depredations and attitudes of local pastoralists toward carnivores in the Qinghai Lake Region, China. Wildlife Biology, 21, 204-212. 
Li, G. \& Fang, C. 2014. Global mapping and estimation of ecosystem services values and gross domestic product: A spatially explicit integration of national 'green GDP' accounting. Ecological Indicators, 46, 293-314.

Liu, F., McShea, W.J., Garshelis, D.L., Zhu, X., Wang, D. \& Shao, L. 2011. Human-wildlife conflicts influence attitudes but not necessarily behaviors: Factors driving the poaching of bears in China. Biological Conservation, 144, 538-547.

Llaneza, L., García, E.J., Palacios, V., Sazatornil, V. \& López-Bao, J.V. 2016. Resting in risky environments: the importance of cover for wolves to cope with exposure risk in human-dominated landscapes. Biodiversity and Conservation, 25, 1515-1528.

Lobao, E.S.P. \& Nogueira-Filho, S.L.G. 2011. Human-wildlife Conflicts in the Brazilian Atlantic Forest. Suiform Soundings, 10, 14-22.

Lute, M.L., Carter, N.H., López-Bao, J.V. \& Linnell, J.D.C. 2018. Conservation professionals agree on challenges to coexisting with large carnivores but not on solutions. Biological Conservation, 218, 223-232.

Lute, M.L., Navarrete, C.D., Nelson, M.P. \& Gore, M.L. 2016. Moral dimensions of humanwildlife conflict. Conservation Biology, 30, 1200-1211.

Lyamuya, R.D., Masenga, E.H., Fyumagwa, R.D. \& Røskaft, E. 2014. Human-carnivore conflict over livestock in the eastern part of the Serengeti ecosystem, with a particular focus on the African wild dog Lycaon pictus. Oryx, 48, 1-7.

Madden, F. 2004. Creating coexistence between humans and wildlife: Global perspectives on local efforts to address human-wildlife conflict. Human Dimensions of Wildlife, 9, 247-257.

Marchini, S. \& Macdonald, D.W. 2012. Predicting ranchers' intention to kill jaguars: Case studies in Amazonia and Pantanal. Biological Conservation, 147, 213-221.

Marseille, M.M., Elands, B.H.M. \& van den Brink, M.L. 2012. Experiencing polar bears in the zoo: Feelings and cognitions in relation to a visitor's conservation attitude. Human Dimensions of Wildlife, 17, 29-43.

McManus, J.S., Dickman, A.J., Gaynor, D., Smuts, B.H. \& MacDonald, D.W. 2014. Dead or alive? Comparing costs and benefits of lethal and non-lethal human-wildlife conflict mitigation on livestock farms. Oryx, 49, 1-9.

MEA. Millenium Ecosystem Assessment. 2005. Ecosystems and human well-being: Synthesis. Island Press, Washington, D.C.

Meadows, D. 1999. Leverage points: Places to intervene in a system. Hartland: The Sustainability Institute.

Melo, A.L.T., Aguiar, D.M., Spolidorio, M.G., Yoshinari, N.H., Matushima, E.R., Labruna, M.B. \& Horta, M.C. 2016. Serological evidence of exposure to tick-borne agents in opossums (Didelphis spp.) in the State of São Paulo, Brazil. Revista Brasileira de Parasitologia Veterinária, 25, 348-352. 
Michalski, F., Boulhosa, R.L.P., Faria, A. \& Peres, C.A. 2006. Human-wildlife conflicts in a fragmented Amazonian forest landscape: Determinants of large felid depredation on livestock. Animal Conservation, 9, 179-188.

Michalski, F. \& Peres, C.M.A. 2007. Disturbance-mediated mammal persistence and abundance-area relationships in Amazonian forest fragments. Conservation Biology, $21,1626-1640$.

Miles, M.A., Feliciangeli, M.D. \& de Arias, A.R. 2003. American trypanosomiasis (Chagas' disease) and the role of molecular epidemiology in guiding control strategies. $B M J$ : British Medical Journal, 326, 1444-1448.

Miller, J.R.B. 2015. Mapping attack hotspots to mitigate human-carnivore conflict: approaches and applications of spatial predation risk modeling. Biodiversity and Conservation, 24, 2887-2911.

Minnie, L., Boshoff, A.F. \& Kerley, G.I.H. 2015. Vegetation type influences livestock predation by leopards : Implications for conservation in agro-ecosystems. African Journal of Wildlife Research, 45, 204-214.

Myers, N., Mittermeier, R.A., Mittermeier, C.G., da Fonseca, G.A.B. \& Kent, J. 2000. Biodiversity hotspots for conservation priorities. Nature, 403, 853.

Osgood, C.E., Suci, G.J. \& Tannenbaum, P.H. 1978. The measurement of meaning, University of Illinois Press. Urbana-Champaign.

Palmeira, F.B.L., Trinca, C.T. \& Haddad, C.M. 2015. Livestock Predation by Puma (Puma concolor) in the Highlands of a Southeastern Brazilian Atlantic Forest. Environmental Management, 56, 903-915.

Pasher, J., Mitchell, S.W., King, D.J., Fahrig, L., Smith, A.C. \& Lindsay, K.E. 2013. Optimizing landscape selection for estimating relative effects of landscape variables on ecological responses. Landscape Ecology, 28, 371-383.

Patterson, B.D., Kasiki, S.M., Selempo, E. \& Kays, R.W. 2004. Livestock predation by lions (Panthera leo) and other carnivores on ranches neighboring Tsavo National Parks, Kenya. Biological Conservation, 119, 507-516.

Peterson, M.N., Birckhead, J.L., Leong, K., Peterson, M.J. \& Peterson, T.R. 2010. Rearticulating the myth of human-wildlife conflict. Conservation Letters, 3, 74-82.

Phelps, E.A. 2006. Emotion and cognition: Insights from studies of the human amygdala. Annual Review of Psychology, 57, 27-53.

Piecewise SEM. 2018. Piecewise Structural Equation Modeling. Available at: https://cran.rproject.org/web/packages/piecewiseSEM/README.html. Access in March 15th, 2018.

Piédallu, B., Quenette, P.-Y., Mounet, C., Lescureux, N., Borelli-Massines, M., Dubarry, E., Camarra, J.-J. \& Gimenez, O. 2016. Spatial variation in public attitudes towards brown bears in the French Pyrenees. Biological Conservation, 197, 90-97. 
R Core Team. 2016. R: A language and environment for statistical computing, $\mathrm{R}$ Foundation for Statistical Computing, Vienna, Austria. URL https://www.R-project.org/.

Rasmussen, L.V., Christensen, A.E., Danielsen, F., Dawson, N., Martin, A., Mertz, O., Sikor, T., Thongmanivong, S. \& Xaydongvanh, P. 2017. From food to pest: Conversion factors determine switches between ecosystem services and disservices. Ambio, 46, 173-183.

Redpath, S.M., Young, J., Evely, A., Adams, W.M., Sutherland, W.J., Whitehouse, A., Amar, A., Lambert, R.A., Linnell, J.D.C., Watt, A. \& Gutiérrez, R.J. 2013. Understanding and managing conservation conflicts. Trends in Ecology and Evolution, 28, 100-109.

Regolin, A.L., Cherem, J.J., Graipel, M.E., Bogoni, J.A., Ribeiro, J.W., Vancine, M.H., Tortato, M.A., Oliveira-Santos, L.G., Fantacini, F.M., Luiz, M.R., Castilho, P.V.d., Ribeiro, M.C. \& Cáceres, N.C. 2017. Forest cover influences occurrence of mammalian carnivores within Brazilian Atlantic Forest. Journal of Mammalogy, 98, 1721-1731.

Reibelt, L.M., Woolaver, L., Moser, G., Randriamalala, I.H., Raveloarimalala, L.M., Ralainasolo, F.B., Ratsimbazafy, J. \& Waeber, P.O. 2017. Contact matters: Local people's perceptions of hapalemur alaotrensis and implications for conservation. International Journal of Primatology, 38, 588-608.

Ribeiro, F.S. 2016. Disturbance or propagule pressure? Unraveling the drivers of the invasion by free-ranging dogs in Atlantic forest. Thesis (Master), Departamento de Ecologia, Insituto de Biociências, Universidade de São Paulo.

Ribeiro, M.C., Metzger, J.P., Martensen, A.C., Ponzoni, F.v.J. \& Hirota, M.r.M. 2009. The Brazilian Atlantic Forest: How much is left, and how is the remaining forest distributed? Implications for conservation. Biological Conservation, 142, 1141-1153.

Rogala, J.K., Hebblewhite, M., Whittington, J., White, C.A., Coleshill, J. \& M. Musiani, M. 2011. Human activity differentially redistributes large mammals in the Canadian Rockies national parks. Ecology and Society, 16, 16.

Røskaft, E., Händel, B., Bjerke, T. \& Kaltenborn, B.P. 2007. Human attitudes towards large carnivores in Norway. Wildlife Biology, 13, 172-185.

Sandberg, T. \& Conner, M. 2008. Anticipated regret as an additional predictor in the theory of planned behaviour: A meta-analysis. British Journal of Social Psychology, 47, 589606.

Schaubroeck, T. 2017. A need for equal consideration of ecosystem disservices and services when valuing nature; countering arguments against disservices. Ecosystem Services, 26, 95-97.

Soto-Shoender, J.R. \& Giuliano, W.M. 2011. Predation on livestock by large carnivores in the tropical lowlands of Guatemala. Oryx, 45, 561-568. 
Sponarski, C.C., Vaske, J.J., Bath, A.J. \& Loeffler, T.A. 2016. Changing attitudes and emotions toward coyotes with experiential education. The Journal of Environmental Education, 47, 296-306.

Sunquist, M. \& Sunquist, F. 2017. Wild Cats of the World. University of Chicago Press.

Thorn, M., Green, M., Dalerum, F., Bateman, P.W. \& Scott, D.M. 2012. What drives humancarnivore conflict in the North West Province of South Africa? Biological Conservation, 150, 23-32.

Thorn, M., Green, M., Marnewick, K. \& Scott, D.M. 2014. Determinants of attitudes to carnivores: implications for mitigating human-carnivore conflict on South African farmland. Oryx, 49, 1-8.

Tisovec-Dufner, K.C. 2018. Intention of preserving forest remnants among landowners in the Atlantic Forest: the role of the ecological context and experiences with nature. Thesis (Master), Departamento de Ecologia, Instituto de Biociências, Universidade de São Paulo.

Treves, A., Naughton-Treves, L., Harper, E.K., Mladenoff, D.J., Rose, R.A., Sickley, T.A. \& Wydeven, A.P. 2004. Predicting human-carnivore conflict: A spatial model derived from 25 years of data on wolf predation on livestock. Conservation Biology, 18, 114125.

Treves, A., Naughton-Treves, L. \& Shelley, V. 2013. Longitudinal analysis of attitudes toward wolves. Conservation Biology, 27, 315-323.

Tucker, M.A., Böhning-Gaese, K., Fagan, W.F., Fryxell, J.M., Van Moorter, B., Alberts, S.C., Ali, A.H., Allen, A.M., Attias, N., Avgar, T., Bartlam-Brooks, H., Bayarbaatar, B., Belant, J.L., Bertassoni, A., Beyer, D., Bidner, L., van Beest, F.M., Blake, S., Blaum, N., Bracis, C., Brown, D., de Bruyn, P.J.N., Cagnacci, F., Calabrese, J.M., CamiloAlves, C., Chamaillé-Jammes, S., Chiaradia, A., Davidson, S.C., Dennis, T., DeStefano, S., Diefenbach, D., Douglas-Hamilton, I., Fennessy, J., Fichtel, C., Fiedler, W., Fischer, C., Fischhoff, I., Fleming, C.H., Ford, A.T., Fritz, S.A., Gehr, B., Goheen, J.R., Gurarie, E., Hebblewhite, M., Heurich, M., Hewison, A.J.M., Hof, C., Hurme, E., Isbell, L.A., Janssen, R., Jeltsch, F., Kaczensky, P., Kane, A., Kappeler, P.M., Kauffman, M., Kays, R., Kimuyu, D., Koch, F., Kranstauber, B., LaPoint, S., Leimgruber, P., Linnell, J.D.C., López-López, P., Markham, A.C., Mattisson, J., Medici, E.P., Mellone, U., Merrill, E., de Miranda Mourão, G., Morato, R.G., Morellet, N., Morrison, T.A., Díaz-Muñoz, S.L., Mysterud, A., Nandintsetseg, D., Nathan, R., Niamir, A., Odden, J., O’Hara, R.B., Oliveira-Santos, L.G.R., Olson, K.A., Patterson, B.D., Cunha de Paula, R., Pedrotti, L., Reineking, B., Rimmler, M., Rogers, T.L., Rolandsen, C.M., Rosenberry, C.S., Rubenstein, D.I., Safi, K., Saïd, S., Sapir, N., Sawyer, H., Schmidt, N.M., Selva, N., Sergiel, A., Shiilegdamba, E., Silva, J.P., Singh, N., et al. 2018. Moving in the Anthropocene: Global reductions in terrestrial mammalian movements. Science, 359, 466. 
van Velden, J.L., Smith, T. \& Ryan, P.G. 2016. Cranes and crops: Investigating farmer tolerances toward crop damage by threatened blue cranes (Anthropoides paradiseus) in the Western Cape, South Africa. Environmental Management, 58, 972-983.

Vaske, J.J., Roemer, J.M. \& Taylor, J.G. 2013. Situational and emotional influences on the acceptability of wolf management actions in the Greater Yellowstone ecosystem. Wildlife society bulletin, 37, 122-128.

Vaz, A.S., Kueffer, C., Kull, C.A., Richardson, D.M., Vicente, J.R., Kühn, I., Schröter, M., Hauck, J., Bonn, A. \& Honrado, J.P. 2017. Integrating ecosystem services and disservices: insights from plant invasions. Ecosystem Services, 23, 94-107.

Wald, D.M., Lohr, C.A., Lepczyk, C.A., Jacobson, S.K. \& Cox, L.J. 2016. A comparison of cat related risk perceptions and tolerance for outdoor cats in Florida and Hawaii. Conservation Biology, 30, 1233-1244.

Woodroffe, R., Thirgood, S. \& Rabinowitz, A. 2005. People and Wildlife: conflict or coexistence?. Cambridge University Press, Cambridge.

Yeo, M., Acosta, N., Llewellyn, M., Sánchez, H., Adamson, S., Miles, G.A.J., López, E., González, N., Patterson, J.S., Gaunt, M.W., Arias, A.R.d. \& Miles, M.A. 2005. Origins of Chagas disease: Didelphis species are natural hosts of Trypanosoma cruzi I and armadillos hosts of Trypanosoma cruzi II, including hybrids. International Journal for Parasitology, 35, 225-233.

Zajac, R.M., Bruskotter, J.T., Wilson, R.S. \& Prange, S. 2012. Learning to live with black bears: A psychological model of acceptance. The Journal of Wildlife Management, 76, 1331-1340.

Zaradic, P.A., Pergams, O.R.W. \& Kareiva, P. 2009. The Impact of nature experience on willingness to support conservation. PLoS ONE, 4, e7367.

Zhang, W., Goodale, E. \& Chen, J. 2014. How contact with nature affects children's biophilia, biophobia and conservation attitude in China. Biological Conservation, 177, 109-116.

Zimmermann, A., Walpole, M.J. \& Leader Williams, N. 2005. Cattle ranchers' attitudes to conflicts with jaguar Panthera onca in the Pantanal of Brazil. Oryx, 39, 406-412. 


\section{SUPPORTING INFORMATION}

\section{Appendix A - Selection of properties and interviewees}

Here we describe the reasons why we excluded properties (Table A1) or landowners (Table A2) from the sample, indicating the final number of properties checked in the field and of participants that were interviewed.

Table A1. Selection of properties within the 13 study landscapes. FC = proportion of remaining forest cover within the landscape; $\mathrm{CAR}=$ proportion of the landscape area declared to the Rural Environmental Register; Total = properties completely within or intersecting the limits of study landscapes; No house = properties excluded for having no house or having a house outside landscape limits; Two landscapes = properties excluded for intersecting two landscapes; Forest $<1$ ha = properties excluded for having less than 1 ha of forest; New sample $=$ number of sampled additional properties chosen among those with less than 1 ha to increase the number of interviewees in the study; Visited = properties visited in the field (grey shadow).

\begin{tabular}{ccccccccc}
\hline Landscape & $\begin{array}{c}\text { FC } \\
(\boldsymbol{\%})\end{array}$ & $\begin{array}{c}\text { CAR } \\
(\boldsymbol{\%})\end{array}$ & Total & No house & $\begin{array}{c}\text { Two } \\
\text { landscapes }\end{array}$ & $\begin{array}{c}\text { Forest } \\
<\mathbf{1} \text { ha }\end{array}$ & $\begin{array}{c}\text { New } \\
\text { sample }\end{array}$ & Visited \\
\hline 1 & 10 & 72 & 107 & 13 & 0 & 80 & 6 & 20 \\
2 & 14 & 72 & 96 & 13 & 0 & 60 & 5 & 28 \\
3 & 15 & 55 & 51 & 6 & 0 & 31 & 6 & 20 \\
4 & 15 & 40 & 101 & 10 & 0 & 60 & 6 & 37 \\
5 & 18 & 70 & 132 & 16 & 0 & 77 & 2 & 41 \\
6 & 24 & 73 & 109 & 18 & 1 & 63 & 0 & 27 \\
7 & 30 & 56 & 107 & 27 & 0 & 58 & 5 & 27 \\
8 & 31 & 58 & 100 & 15 & 0 & 51 & 1 & 35 \\
9 & 31 & 38 & 55 & 11 & 1 & 19 & 5 & 29 \\
10 & 32 & 42 & 89 & 23 & 0 & 47 & 4 & 23 \\
11 & 39 & 43 & 107 & 12 & 0 & 71 & 6 & 30 \\
12 & 46 & 78 & 38 & 12 & 1 & 10 & 1 & 16 \\
13 & 49 & 70 & 31 & 11 & 0 & 5 & 3 & 18 \\
\hline & & Total & $\mathbf{1 1 2 3}$ & $\mathbf{1 8 7}$ & $\mathbf{3}$ & $\mathbf{6 3 2}$ & $\mathbf{5 0}$ & $\mathbf{3 5 1}$ \\
\hline
\end{tabular}


Table A2. Selection of interviewees within the 13 study landscapes. FC = proportion of remaining forest cover within the landscape; Visited = number of visited properties in each landscape; No livestock = number of properties excluded for having no livestock; No resident $=$ number of properties excluded for having no residents; Tenant $=$ number of properties excluded for being leased or rented; Housekeeper $=$ number of properties excluded because owners do not reside in the property, but entrust a housekeeper to take care of it; Refuse = number of properties whose owners refused to participate in the study; Interviews = number of properties whose owner (self-declared as responsible for managing livestock) was interviewed in each landscape (grey shadow).

\begin{tabular}{ccccccccc}
\hline Landscape & $\begin{array}{c}\text { FC } \\
(\boldsymbol{\%})\end{array}$ & Visited & $\begin{array}{c}\text { No } \\
\text { livestock }\end{array}$ & $\begin{array}{c}\text { No } \\
\text { resident }\end{array}$ & Tenant & Housekeeper & Refuse & Interviews \\
\hline 1 & 10 & 20 & 0 & 5 & 1 & 4 & 0 & 10 \\
2 & 14 & 28 & 6 & 7 & 0 & 5 & 0 & 10 \\
3 & 15 & 20 & 0 & 4 & 1 & 4 & 4 & 7 \\
4 & 15 & 37 & 6 & 7 & 2 & 7 & 6 & 9 \\
5 & 18 & 41 & 5 & 12 & 1 & 10 & 1 & 12 \\
6 & 24 & 27 & 1 & 11 & 1 & 2 & 1 & 11 \\
7 & 30 & 27 & 3 & 6 & 0 & 7 & 3 & 8 \\
8 & 31 & 35 & 1 & 13 & 3 & 6 & 0 & 12 \\
9 & 31 & 29 & 1 & 12 & 0 & 4 & 2 & 10 \\
10 & 32 & 23 & 3 & 7 & 0 & 5 & 0 & 8 \\
11 & 39 & 30 & 4 & 11 & 0 & 3 & 2 & 10 \\
12 & 46 & 16 & 1 & 5 & 0 & 3 & 3 & 4 \\
13 & 49 & 18 & 4 & 5 & 1 & 3 & 2 & 3 \\
\hline & Total & $\mathbf{3 5 1}$ & $\mathbf{1 0 5}$ & $\mathbf{3 5}$ & $\mathbf{1 0}$ & $\mathbf{6 3}$ & $\mathbf{2 4}$ & $\mathbf{1 1 4}$ \\
\hline
\end{tabular}




\section{Appendix B - Pilot study}

During a pilot study, we informally talked to 32 people in the study region (but outside our 13 landscapes). To ensure we used the proper popular names for the target species, i.e., opossum (Didelphis aurita), crab-eating fox (Cerdocyon thous) and puma (Puma concolor), we showed people images of the target species and asked how they name them and if they know any other name for them. To define the adequate time period for measuring contact with, and attacks from, each species, we informally asked these people how frequently they encountered and had livestock depredated by each species.

We also elicited the salient emotions and beliefs associated with the target species, asking them in an open-ended question format, what they believed they would feel by seeing or thinking about those species and the benefits and risks (i.e., advantages and disadvantages) they believed those species bring them. Among the eight emotions interviewees mentioned, three have a negative valence (fear, anger and disgust) and five a positive valence (joy, excitement, surprise, interest and pity). We selected the four most frequently mentioned emotions to be included in the indices for emotions (Appendix F). The same six positive beliefs were mentioned by interviewees as associated with benefits brought about by the opossum and crab-eating, of which five were also perceived as benefits brought about by the puma. The same four negative beliefs were mentioned by interviewees as associated with risks brought about by the three species (Appendix F).

Finally, we tested the questionnaire with 16 people in the study region, outside the landscapes, to better adjust language, structure and order of the questions, test the identification plates (Appendix D) and the visual scales (Appendix G). 


\section{Appendix C - Socio-demographic variables, raised livestock and dependence on livestock}

All questions were written in Portuguese in a language style used by local people (see Appendix I for the complete original version). Here we translated the questions to English trying to preserve the meaning meant in Portuguese. Questions used to assess sociodemographic variables referred to sex (female or male), age, place of birth (in which city, state and country the person was born), main activity (i.e., the activity the person dedicates most of his/her time), and number of years of formal education at different levels (elementary school, high school, college degree, specialization and/or graduate studies). We also asked the total number of individuals of each livestock (e.g., cattle, horse, poultry, pigs, sheep) raised in the property. Fish and honey bees were not taken into consideration.

Dependence on livestock was measured with an index computed by the sum of the points associated with the four numbered questions below. Unnumbered questions were used only as introductory questions to direct the interview and were not used to compute dependence on livestock.

1. Do you raise your livestock only in this property or divided in different properties? Answers: Only in this property (2 points)

Divided in different properties (1 point)

Do you sell part of your livestock you raise or their products, such as milk and eggs? Yes | No

2. The money you earn by selling your livestock or their products represents about half, less than half or more than half of the money you and the people you live with earn?

Answers: Less than half(1 points) | Half(2 points)

More than half (3 points) | Nothing (no point)

Do you and the people who you live with eat meat from your livestock? Yes $\mid$ No

3. Does this meat from your livestock represent about half, less than half or more than half the meat you and the people who you live with eat?

Answers: Less than half (1 points) | Half (2 points)

More than half (3 points) | Nothing (no point)

Do you and the people you live with eat part of the products from your livestock, such as milk and eggs? Yes | No

4. Do these products from your livestock (excluding meat) represent about half, less than half or more than half of the animal products you and the people who you live with eat?

Answers: Less than half (1 points) | Half (2 points)

More than half (3 points) | Nothing (no point) 


\section{Appendix D - Identification of the target species}

During the interview, participants were given plates (in color) with images of different mammal species occurring in the study area (Figures D1 and D2) and were asked, by using the popular names elicited during the pilot study (Appendix B), to identify the target species. The interview was carried only with participants who were able to correctly identify at least one target species, but only questions related to the identified target species were made during the interview. The popular name of the target species used during the interview was the popular name used by the participant.

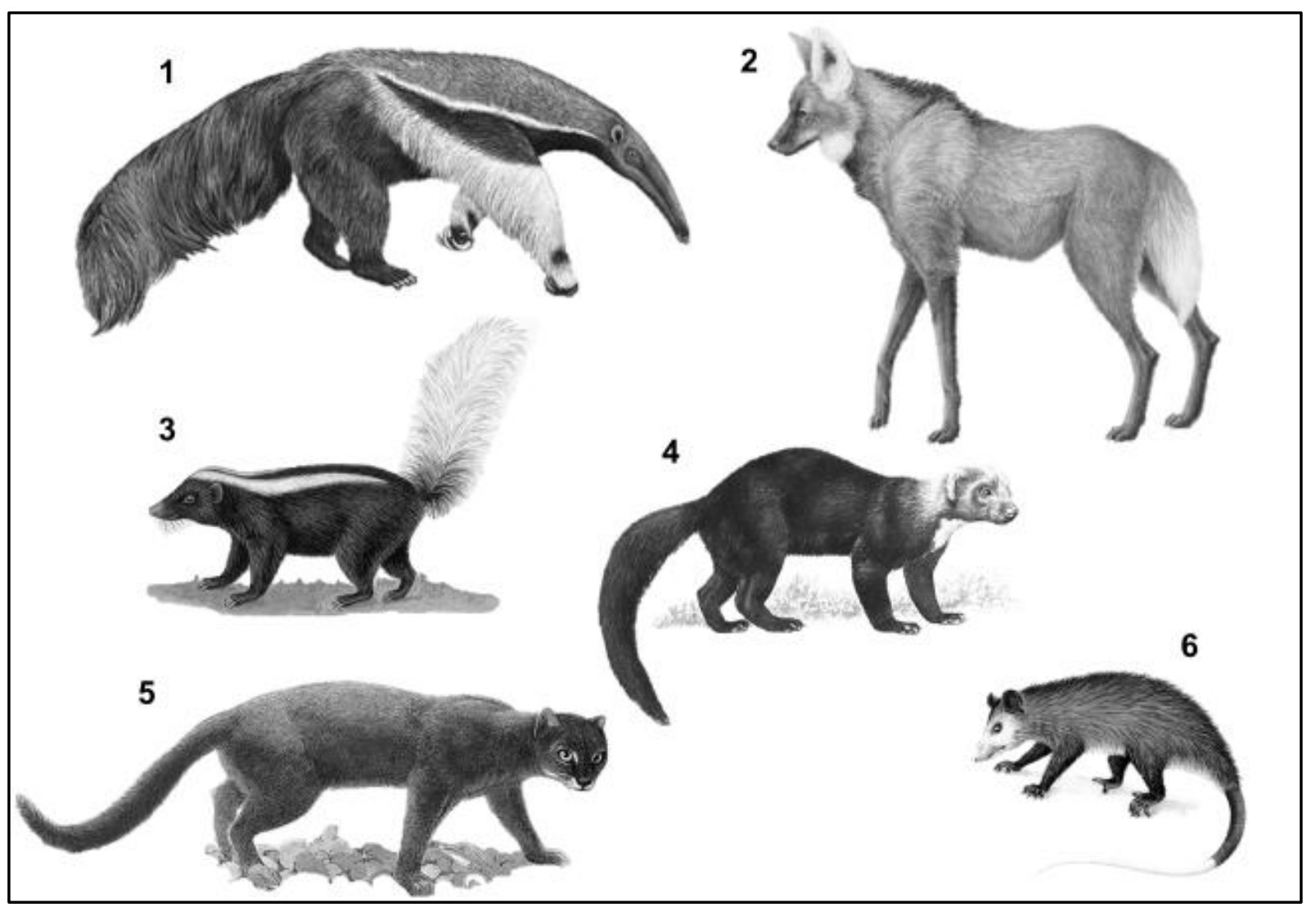

Figure D1. Plate used for ensuring that participants were able to identify/recognize the target species (in bold): 1) giant anteater (Myrmecophaga tridactyla), 2) maned wolf (Chrysocyon brachyurus), 3) hog-nosed skunk (Conepatus sp.), 4) tayra (Eira barbara), 5) Jaguarundi (Puma yagouaroundi) and 6) Opossum (Didelphis aurita). The order of the figures was randomly established. 


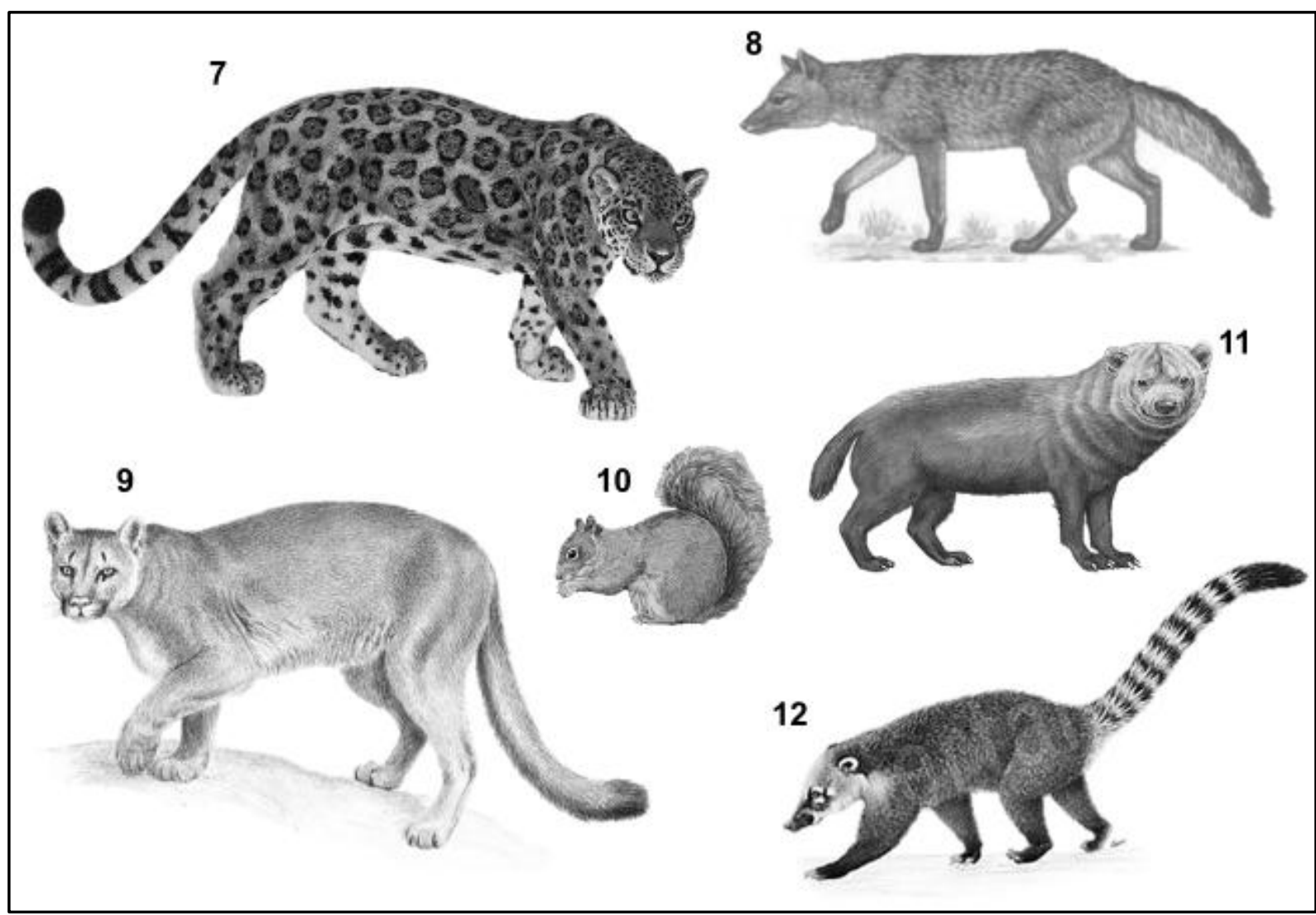

Figure D2. Plate used for ensuring that participants were able to identify/recognize the target species (in bold): 7) jaguar (Panthera onca), 8) crab-eating fox (Cerdocyon thous), 9) puma (Puma concolor), 10) bushy-tailed squirrel (Sciurus sp.), 11) bush dog (Speothos venaticus) and 12) ring-tailed coati (Nasua nasua). The order of the figures was randomly established. 


\section{Appendix E - Quantifying experiences with the target species}

All questions were written in Portuguese in a style used by local people (see Appendix I for the complete original version). Here we translated the questions to English trying to preserve the meaning meant in Portuguese. Below, we present the questions used to measure the contact with, and the damage from, the target species participants had in the previous 6 months, 12 months and 5 years for the opossum, the crab-eating fox and the puma, respectively.

\section{Contact}

1. Have you ever seen a (name given to the target species) face-to-face in the last (period of time)? Yes | No. If yes: How many times?

2. Has anyone of your family or any friend talked to you about (name given to the target species) roaming about their properties or attacking their livestock in the last (period of time)? Yes | No. If yes: How many times?

\section{Damage}

1. In the last (period of time), have you realized you lost livestock, including (livestock potentially attacked), due to an attack from (name given to the target species)?

Yes | No.

If yes: How many times have you realized you lost livestock, including (livestock potentially attacked), due to an attack of (name given to the target species)?

If yes: How many individuals were lost in each attack event? 


\section{Appendix F - Quantifying psychological variables towards the target species}

All questions were written in Portuguese in a style used by local people (see Appendix I for the complete original version). Here we translated the questions to English trying to preserve the meaning meant in Portuguese. Below, we present the questions used to measure the psychological variables, i.e., indices for emotions, beliefs and tolerance, and the scale for attitude for the target species, i.e., opossum (Didelphis aurita), crab-eating fox (Cerdocyon thous) and puma (Puma concolor). The visual scale used to help participants answering is presented in the Appendix G.

Emotions - four emotions - fear, disgust, joy and interest (Appendix B) - were assessed in two different contexts: just thinking of the species and encountering the species.

1. Could you please indicate to me in this scale how much (emotion) do you feel when you THINK of a (name given to the target species)?

2. Could you please indicate to me in this scale how much (emotion) do you feel when you ENCONTER the (name given to the target species) right in front of you?

Beliefs - questions for quantifying the strength and evaluation of positive beliefs or perception of benefits are presented in Table F1, and questions for quantifying the cognitive and affective components of negative beliefs or perception of risk are presented in Table F2.

Attitude towards the target species was assessed using a semantic differential scale using five pair of adjectives: bad/ good; boring/ exciting; harmful/ beneficial; unpleasant/ pleasant; ugly/ beautiful.

1. Do you think that (name given to the species) is (pair of adjectives)? Please indicate to me in this scale how much (pair of adjectives) you think that (name given to the species) is.

\section{Tolerance}

1. In your opinion, the population of (name given to the species) here in the region should be bigger or smaller than today? Please indicate to me in this scale how bigger or smaller it should be.

2. Now thinking about a larger area, such as the State of São Paulo, in your opinion, the population of (name given to the species) should be bigger or smaller than today? Please indicate to me in this scale how bigger or smaller it should be. 
Table F1. Items used to measure positive beliefs towards the target species: opossum (Didelphis aurita), crab-eating fox (Cerdocyon thous) and puma (Puma concolor) perception of benefits according to the evaluation-value (EV) model. $\mathrm{B}=$ Strength of belief; $\mathrm{E}$ $=$ Evaluation of the belief. B3 and E3 were asked only for opossum and crab-eating fox.

Could you please indicate to me how much you agree that:

From 1 (not at all) to 7 (very much)

Now, could you please indicate to me how important to you is that:

From 1 (not important at all) to 7 (very important)

B1. having (name given to the target species) in this area helps to attract tourists E1. tourists are attracted to the region. who like animals.

$\mathrm{B} 2$. (name given to the target species) eats animals that might cause problems, like:

Opossum: snakes, spiders or scorpions. E2. animals that might cause problems are Crab-eating fox: mice and spiders. controlled.

Puma: wild boars and capybaras

$\mathrm{B} 3$. (name given to the target species) helps to spread seeds of fruit trees.

E3. seeds of fruit trees are dispersed.

B4. (name given to the target species) is useful to studies and scientific research about animals.

E4. studies and scientific research about wild animals are done.

B5. knowing that (name given to the target species) are well and alive brings me E5. animals are well and alive. satisfaction.

B6. knowing my children and grandchildren will get to know (name given to the target E6. children get to know animals. species) brings me satisfaction. 
Table F2. Items used to measure negative beliefs towards the target species: opossum (Didelphis aurita), crab-eating fox (Cerdocyon thous) and puma (Puma concolor) perception of risks. $\mathrm{R}=$ Strength/cognitive component of risk; $\mathrm{E}=$ Evaluation/emotive component of risk. Periods of time: 6 months, 12 months and 5 years for the opossum, the crab-eating fox or the puma, respectively.

\section{Could you please indicate to me, for you, Now, could you please indicate to me how what are the chances of: concerned are you that: \\ From 1 (no chance at all) to 7 (very high From 1 (not important at all) to 7 (very chances) important)}

$\mathrm{R} 1$. (name given to the target species) attacking your livestock in the next (period of time)?

Obs: Include eggs for the opossum.

E1. (name given to the target species) attack your livestock?

Obs: Include eggs for the opossum.

$\mathrm{R} 2$. (name given to the target species) attacking people in the next (period of time)?

E2. (name given to the target species) attack people?

R3. (name given to the target species) spreading disease to your livestock in the next (period of time)?
E3. (name given to the target species) spreads disease to your livestock?
R4. (name given to the target species) spreading disease to people in the next (period of time)?
E4. (name given to the target species) spreads disease to people? 


\section{Appendix G - Visual scales}

Two visual scales (in color) were used for reporting the response of interviewees to items in indices and scales: one for unidirectional items and one for bidirectional items (Figure G1). Although in both visual scales the numbers in the circles are from 0 to 6 , we coded them as 1 to 7 and -3 to +3 , respectively. This was done because the numbers aimed at facilitating the responses (i.e., the circle position) and to avoid biases, e.g., participant choosing only the highest options for being easier.

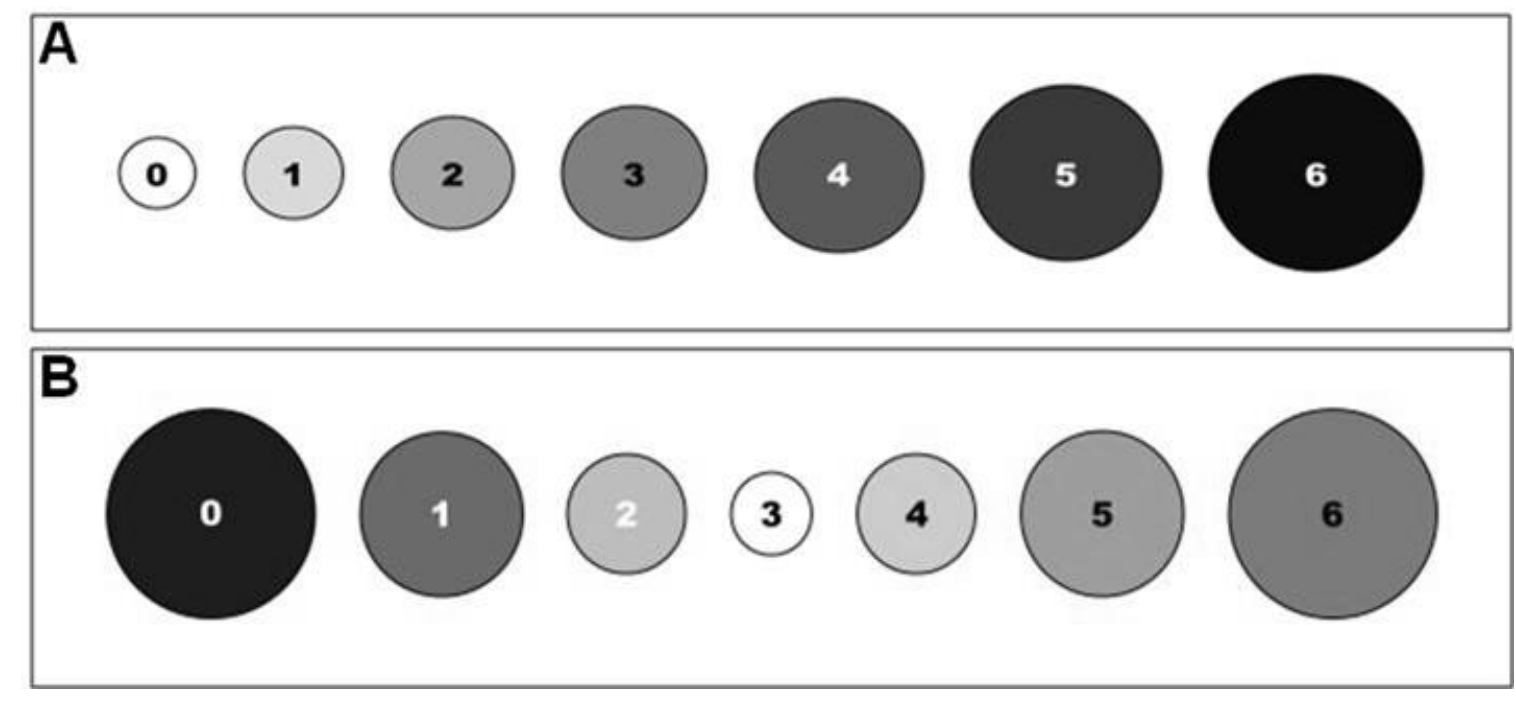

Figure G1. Visual scales used for reporting the response of interviewees to items in indices and scales. A) Scale for unidirectional items; B) scale for bidirectional items. 


\section{Appendix $\mathrm{H}$ - Evaluation of the attitude scale}

Scales items should measure the same underlying construct, and a high correlation among items is expected (Streiner, 2003; Widhiarso \& Ravand, 2014). We used two different methods to evaluate the quality of the attitude scale: the Cronbach's alpha coefficient $(\alpha)$, an evaluation based on internal consistency between items (Streiner, 2003), and the omega total coefficients $(\omega t)$, which estimates reliability from a factorial analysis framework. For both methods, values higher than 0.8 are considered good (Widhiarso \& Ravand, 2014). To evaluate scale unidimensionality, we used Confirmatory Factor Analysis (CFA) and its associated fit measures: an absolute fit index, the Standardized Root Mean Square Residual (SRMSR), and relative fit indices - Comparative Fit Index (CFI) and Tucker-Lewis Index (TLI) (Brown, 2006; Table J1). SRMSR values lower than 0.08 are indicative of an acceptable model; for both the CFI and the TLI indices, values of 0.95 or higher are accepted as indicators of good fit (Hu \& Bentler, 1999). All values indicate the attitude scales for the three species were adequate. Because items of the indices of beliefs, emotions and tolerance are not meant to measure one single construct, there is no need to evaluate them.

Table H1. Evaluation of the reliability and unidimensionality of the attitude scale for each of the target species: opossum (Didelphis aurita), crab-eating fox (Cerdocyon thous) and puma (Puma concolor).

\begin{tabular}{|c|c|c|c|}
\hline & Measure & Species & Attitude \\
\hline \multirow{6}{*}{ Reliability } & \multirow{3}{*}{ Cronbach's $\alpha$} & Opossum & 0.82 \\
\hline & & Crab-eating fox & 0.80 \\
\hline & & Puma & 0.83 \\
\hline & \multirow{3}{*}{$\Omega \mathrm{t}$} & Opossum & 0.87 \\
\hline & & Crab-eating fox & 0.85 \\
\hline & & Puma & 0.87 \\
\hline \multirow{9}{*}{$\begin{array}{l}\text { Construct } \\
\text { unidimensionality }\end{array}$} & \multirow{3}{*}{ SRMSR } & Opossum & 0.046 \\
\hline & & Crab-eating fox & 0.036 \\
\hline & & Puma & 0.019 \\
\hline & \multirow{3}{*}{ CFI } & Opossum & 0.993 \\
\hline & & Crab-eating fox & 0.996 \\
\hline & & Puma & 0.999 \\
\hline & \multirow{3}{*}{ TLI } & Opossum & 0.985 \\
\hline & & Crab-eating fox & 0.991 \\
\hline & & Puma & 0.999 \\
\hline
\end{tabular}




\section{References}

Brown, T.A. 2006. Confirmatory Factor Analysis for Applied Research. Guilford Publications, New York.

Hu, L.-t. \& Bentler, P.M. 1999. Cutoff criteria for fit indexes in covariance structure analysis: Conventional criteria versus new alternatives. Structural Equation Modeling: A Multidisciplinary Journal, 6, 1-55.

Streiner, D.L. 2003. Being Inconsistent About Consistency: When Coefficient Alpha Does and Doesn't Matter. Journal of Personality Assessment, 80, 217-222.

Widhiarso, W. \& Ravand, H. 2014. Estimating reliability coefficient for multidimensional measures: A pedagogical illustration. Review of psychology, 21, 111-121. 


\section{Appendix I - Questionnaire}

Below, we present the complete questionnaire in Portuguese. Not all questions were used in this study.

\section{UNIVERSIDADE DE SÃO PAULO Instituto de Biociências}

Projeto: Interações entre seres humanos e a fauna silvestre: influência do contexto ecológico sobre a atitude das pessoas em relação a espécies de mamíferos silvestres

\begin{tabular}{l} 
Data de entrevista: \\
Entrevista por: \\
Registro da Propriedade (ponto no GPS): \\
Georreferência: \\
Latitude (S): \\
Longitude (W): \\
\hline
\end{tabular}

\begin{tabular}{|c|c|c|c|c|}
\hline Etapa & $\begin{array}{c}\text { Nome do } \\
\text { responsável }\end{array}$ & Data & $\begin{array}{c}\text { Situação dos dados (OK } \\
\text { ou dados faltantes-DF) }\end{array}$ & $\begin{array}{c}\text { Dados faltantes (indicar as } \\
\text { seções e questões com DF) }\end{array}$ \\
\hline Revisão & & & & \\
\hline Planilha & & & & \\
\hline
\end{tabular}

\section{Identificação da propriedade}

\begin{tabular}{l|l} 
Paisagem: & Propriedade:
\end{tabular}

Código da propriedade:

Entrevistado(a): Qual o nome completo do(a) senhor(a)?

\section{INÍCIO DO QUESTIONÁRIO}

Nota: Ler ao(à) potencial entrevistado(a) antes de começar as perguntas:

1. Bom dia/Boa tarde, nós somos estudantes de São Paulo e estamos fazendo uma pesquisa para entender melhor qual é a opinião dos moradores da zona rural aqui da região sobre a natureza. Estamos querendo saber sobre os animais da mata que os moradores costumam ver, os ataques que esses animais fazem nas criações e também sobre as coisas que os moradores costumam fazer quando vão na mata e como é a mata nas propriedades deles.

Nota: Perguntar para TODOS:

2. $O(A)$ senhor(a) mora aqui nesta propriedade? E essa propriedade é do(a) senhor(a)?

Nota: Se SIM para ambas as perguntas do item 2:

3. E o(a) senhor(a) possui algum tipo de criação aqui?

Nota: Se NÃO para alguma das duas perguntas do item 2:

4. E o(a) senhor(a) saberia de algum proprietário que mora aqui e que tenha algum tipo de criação com quem poderíamos conversar? Agradecer e encerrar a conversa.

Nota: Se SIM para a pergunta do item 3:

5. O(A) senhor(a) teria um tempinho para nos ajudar? Nossa conversa deve demora cerca de uns quarenta minutos, mas se estiver ocupado(a) agora, não tem problema, podemos combinar de voltar quando for melhor para o(a) senhor(a).

Gostaríamos desde já de agradecer a participação do(a) senhor(a) neste estudo. Pedimos licença para anotar as respostas porque é muita coisa para lembrarmos de cabeça e para não nos confundirmos depois. Por favor, se ao longo da entrevista o(a) senhor(a) tiver alguma dúvida, não deixe de perguntar.

Nota: Se NÃO para a pergunta do item 4, agradecer e encerrar a conversa. 


\section{I - DADOS SOCIODEMOGRÁFICOS E CARACTERÍSTICAS DA PROPRIEDADE - PARTE I}

Nota: Ler ao(à) entrevistado(a) antes de começar as perguntas:

Vou fazer primeiro algumas perguntas mais gerais sobre o(a) senhor(a) e sobre as plantações e criações que existem nesta propriedade.

1.1. Sexo: Feminino I__ Masculino I__

1.2.1. Tempo na propriedade: Há quanto tempo o(a) senhor(a) mora nesta propriedade?

I__ l anos I__ I meses

I__ I desde que nasceu - Se desde que nasceu, perguntar: E isso faz cerca de quantos anos?

1.2.2. Local de nascimento: Em qual cidade, estado e país o(a) senhor(a) nasceu?

Município I__ Estado I

| País |

1.2.3. Contexto antecedente: Até os seus 10 anos de idade, o(a) senhor(a) e sua família passaram quantos anos morando na cidade e na zona rural? (anotar número de anos) Cidade I___ I Zona rural I

1.3. Tamanho da propriedade: Qual é o tamanho desta propriedade? (marcar a unidade abaixo)

Alqueires I__ Hectares I__ Metros quadrados I__ Outra___ Não sabe I__

1.4. Cultivos: $O(A)$ senhor(a) tem algum tipo de plantação nesta propriedade, que não seja pasto?

Sim I__ Não I

1.5.1. Área para criação: $E$ em relação ao pasto, qual é o tamanho da área de pasto desta propriedade? (marcar a unidade abaixo)

Alqueires I__ Hectares I__ Metros quadrados I__ Outra___ Não sabe I__

1.5.2. Criações: As criações de animais que o(a) senhor(a) possui ficam apenas nesta propriedade ou parte nesta propriedade e parte em outro lugar fora desta propriedade?

Apenas nesta propriedade I__ I Parte nesta propriedade e parte em outro lugar fora desta propriedade

\section{CRIAÇÕES: Quantidade}

\begin{tabular}{|c|c|c|c|c|c|}
\hline $\begin{array}{l}\text { 1.5.3 } \\
\text { Quais criações o(a) senhor(a) tem } \\
\text { no momento nesta propriedade? }\end{array}$ & $\begin{array}{l}\mathbf{1 . 5 . 4} \\
\text { Quantas } \\
\text { cabeças? }\end{array}$ & $\begin{array}{l}1.5 .5 \\
\text { Total } \\
\end{array}$ & $\begin{array}{l}\text { 1.5.3 } \\
\text { Quais criações o(a) senhor(a) tem } \\
\text { no momento nesta propriedade? }\end{array}$ & $\begin{array}{l}\mathbf{1 . 5 . 4} \\
\text { Quantas } \\
\text { cabeças? }\end{array}$ & $\begin{array}{l}1.5 .5 \\
\text { Total }\end{array}$ \\
\hline $1 \square$ Bezerros & & & $\mathbf{1 1} \square$ Angolinhas & & \\
\hline $2 \square$ Vacas e bois & & & $12 \square$ Angolas & & \\
\hline $3 \square$ Potros & & & $13 \square$ Filhotes de patos e gansos & & \\
\hline $4 \square$ Cavalos e éguas & & & $14 \square$ Patos e gansos & & \\
\hline $5 \square$ Cabritinhos e ovelhinhas & & & $15 \square$ Cachorrinhos & & \\
\hline $6 \square$ Cabras e ovelhas & & & $16 \square$ Cachorros & & \\
\hline $7 \square$ Porquinhos & & & Outras: & & \\
\hline $8 \square$ Porcos & & & 17 & & \\
\hline $9 \square$ Pintinhos & & & 18 & & \\
\hline $10 \square$ Galinhas e galos & & & 19 & & \\
\hline
\end{tabular}




\begin{tabular}{|c|c|c|c|c|c|c|c|}
\hline \multirow{2}{*}{$\begin{array}{l}\mathrm{O}(\mathrm{A}) \text { senhor(a) deixa essas } \\
\text { criações protegidas de possíveis } \\
\text { ataques de animais da mata, } \\
\text { como em curral ou galinheiro? }\end{array}$} & \multirow{2}{*}{$\begin{array}{l}1.5 .6 \\
\text { SIM } \\
\text { ou } \\
\text { NÃO }\end{array}$} & \multicolumn{2}{|c|}{$\begin{array}{l}\text { 1.5.7 Todas as cabeças ou } \\
\text { apenas parte delas? } \\
\text { Se PARTE DELAS, quantas? }\end{array}$} & \multirow{2}{*}{$\begin{array}{l}1.5 .8 \\
\text { Quantas } \\
\text { vezes por } \\
\text { semana? }\end{array}$} & \multicolumn{3}{|c|}{$\begin{array}{l}\text { 1.5.9 } \\
\text { Durante o dia, a noite } \\
\text { ou o tempo todo? }\end{array}$} \\
\hline & & Todas & Parte (quant.) & & Dia & Noite & Todo \\
\hline $1 \square$ Bezerros & $\mathrm{S} \mid \mathrm{N}$ & & & & & & \\
\hline $2 \square$ Vacas e bois & $\mathrm{S} \mid \mathrm{N}$ & & & & & & \\
\hline $3 \square$ Potros & $\mathrm{S} \mid \mathrm{N}$ & & & & & & \\
\hline $4 \square$ Cavalos e éguas & $\mathrm{S} \mid \mathrm{N}$ & & & & & & \\
\hline $5 \square$ Cabritinhos e ovelhinhas & $\mathrm{S} \mid \mathrm{N}$ & & & & & & \\
\hline $6 \square$ Cabras e ovelhas & $\mathrm{S} \mid \mathrm{N}$ & & & & & & \\
\hline $7 \square$ Porquinhos & $S \mid N$ & & & & & & \\
\hline $8 \square$ Porcos & $S \mid N$ & & & & & & \\
\hline $9 \square$ Pintinhos & $\mathrm{S} \mid \mathrm{N}$ & & & & & & \\
\hline $10 \square$ Galinhas e galos & $\mathrm{S} \mid \mathrm{N}$ & & & & & & \\
\hline $11 \square$ Angolinhas & $\mathrm{S} \mid \mathrm{N}$ & & & & & & \\
\hline $12 \square$ Angolas & $S \mid N$ & & & & & & \\
\hline $13 \square$ Filhotes de patos e gansos & $\mathrm{S} \mid \mathrm{N}$ & & & & & & \\
\hline $14 \square$ Patos e gansos & $\mathrm{S} \mid \mathrm{N}$ & & & & & & \\
\hline $15 \square$ Cachorrinhos & $\mathrm{S} \mid \mathrm{N}$ & & & & & & \\
\hline $16 \square$ Cachorros & $S \mid N$ & & & & & & \\
\hline \multicolumn{8}{|l|}{ Outras: } \\
\hline 17 & $\mathrm{~S} \mid \mathrm{N}$ & & & & & & \\
\hline 18 & $\mathrm{~S} \mid \mathrm{N}$ & & & & & & \\
\hline 19 & $S \mid N$ & & & & & & \\
\hline
\end{tabular}

Vou fazer agora algumas perguntas sobre o que o(a) senhor(a) faz com suas criações e os produtos que elas dão, por exemplo, se o(a) senhor(a) vende alguma delas ou usa alguma para alimentação. Por favor, para responder, não considere os cachorros, nem interessa). (se a pessoa falou alguma outra criação em OUTRAS que não nos

1.6.1. Vulnerabilidade: $O(A)$ senhor(a) vende parte dos animais que cria ou produtos que eles dão, como leite e ovos?

Sim I__ Não I__ Nota: Se NÃO, marcar NADA na pergunta 1.6.2 e ir para a pergunta 1.6.3.

1.6.2. Vulnerabilidade: $O$ dinheiro que o(a) senhor(a) recebe da venda desses animais ou dos produtos que eles dão contribui com cerca de metade, com menos da metade ou com mais da metade do total da renda das pessoas que moram com o(a) senhor(a) aqui na sua casa?
Nada I__ I
Menos da metade
Metade I__ I
Mais da metade

1.6.3. Vulnerabilidade: $O(A)$ senhor(a) usa a carne dos animais que cria para alimentação do(a) senhor(a) e das pessoas que moram com o(a) senhor(a) aqui na sua casa?

Sim I__ N Não I__ I Nota: Se NÃO, marcar NADA na pergunta 1.6.4 e ir para a pergunta 1.6.5

1.6.4. Vulnerabilidade: Essa carne vinda dos animais de criação que o(a) senhor(a) usa para alimentação contribui com cerca de metade, com menos da metade ou com mais da metade da carne que as pessoas que moram com o(a) senhor(a) aqui na sua casa comem?
Nada I__ l
Menos da metade
Metade
Mais da metade 
1.6.5. Vulnerabilidade: $O(A)$ senhor(a) usa parte dos produtos que seus animais de criação dão, como leite e ovos, para alimentação do(a) senhor(a) e das pessoas que moram com o(a) senhor(a) aqui na sua casa?

Sim I__ Não I__ I Nota: Se NÃO, marcar NADA na pergunta 1.6 .6 e ir para a SEÇÃO II.

1.6.6. Vulnerabilidade: Esses produtos que seus animais de criação dão e que o(a) senhor(a) usa para alimentação contribuem com cerca de metade, com menos da metade ou com mais da metade dos produtos de origem animal, sem considerar a carne, que as pessoas que moram com o(a) senhor(a) aqui na sua casa comem?
Nada
Menos da metade
Metade |
Mais da metade

\section{II - IDENTIFICAÇÃO DE ESPÉCIES, CONTATO E DANOS CAUSADOS PELA FAUNA}

Nota: Ler ao(à) entrevistado(a) antes de começar as perguntas:

Como a gente sabe que dependendo do lugar as pessoas dão nomes diferentes para os animais, para começar a falar sobre os animais da mata, vou mostrar algumas imagens de alguns animais para o(a) senhor(a) e vou pedir para que o(a) senhor(a) aponte, por favor:

Nota: Anotar o número de identificação da figura das espécies apontadas.

\subsection{IDENTIFICAÇÃO DAS ESPÉCIES}

Número da foto

2.1.1 Qual animal o(a) senhor(a) conhece como gambá? Figura 6

2.1.2 Qual animal o(a) senhor(a) conhece como cachorro-do-mato? Figura 8

2.1.3 Qual animal o(a) senhor(a) conhece como onça parda? Figura 9

Nota: Se a pessoa não apontar a imagem esperada para alguma das espécies de interesse, perguntar os outros nomes populares que a espécie não identificada pode ter (tabela abaixo).

2.1.4 GAMBÁ Qual animal o(a) senhor(a) conhece como raposinha?

2.1.5 GAMBÁ Qual animal o(a) senhor(a) conhece como saruê?

2.1.6 CACHORRO-DO-MATO Qual animal o(a) senhor(a) conhece como raposa?

2.1.7 ONÇA PARDA Qual animal o(a) senhor(a) conhece como suçuarana?

2.1.8 ONÇA PARDA Qual animal o(a) senhor(a) conhece como puma?

Nota: ATENÇÃO! Usar o nome que a pessoa der para a espécie durante a entrevista.

Nota: Se a pessoa não apontar a imagem esperada para alguma das espécies de interesse, perguntar o nome que ela dá para a espécie não identificada, apontando as imagens na prancha.

\subsubsection{GAMBÁ Qual o nome que o(a) senhor(a) dá para este animal? Figura 6}

2.1.10 CACHORRO-DO-MATO Qual o nome que o(a) senhor(a) dá para este animal? Figura 8

2.1.11 ONÇA PARDA Qual o nome que o(a) senhor(a) dá para este animal? Figura 9

Nota: ATENÇÃO! Usar o nome que a pessoa der para a espécie durante a entrevista.

Nota: Se a pessoa não identificar qualquer uma das espécies, fazer o questionário apenas para a espécie que ela conhecer. Se ela não identificar nenhuma espécie, ir para a SEÇÃO VI (página 12).

Nota: Ler ao(à) entrevistado(a) antes de começar as perguntas (ATENÇÃO a o nome que a pessoa der para a espécie durante a entrevista): 
Nesta nossa pesquisa nós vamos falar mais sobre três/dois ou uma espécie(s) de animal(is): falar os nomes que a pessoa deu para as espécies e apontar as figuras.

\begin{tabular}{|c|c|c|}
\hline 2.2 CONTATO & Circular & $\begin{array}{l}\text { Quantas } \\
\text { vezes? }\end{array}$ \\
\hline $\begin{array}{l}\text { 2.2.1 O(A) senhor(a) já viu algum gambá na sua frente? Quando foi a última vez que } \\
\text { isso aconteceu? } \quad \text { (perguntas introdutórias - anotar o número de meses atrás) }\end{array}$ & Sim | Não & \\
\hline 2.2.2 O(A) senhor(a) viu algum(a) gambá na sua frente nos últimos 6 meses? & Sim | Não & \\
\hline $\begin{array}{l}\text { 2.2.3 O(A) senhor(a) se lembra de ter visto ou ouvido alguma coisa na TV, no rádio ou } \\
\text { na internet que falava sobre gambá nos últimos } 6 \text { meses? }\end{array}$ & Sim | Não & \\
\hline $\begin{array}{l}\text { 2.2.4 Alguém da sua família ou algum amigo comentou com o(a) senhor(a) de algum } \\
\text { gambá que tenha aparecido na propriedade deles ou que tenha atacado alguma } \\
\text { criação deles nos últimos } 6 \text { meses? }\end{array}$ & Sim | Não & \\
\hline $\begin{array}{l}\text { 2.2.5 E o(a) senhor(a) já viu algum cachorro-do-mato na sua frente? Quando foi a } \\
\text { última vez que isso aconteceu? (perguntas introd. - anotar o número de meses atrás) }\end{array}$ & Sim | Não & \\
\hline $\begin{array}{l}\text { 2.2.6 } O(A) \text { senhor(a) viu algum(a) cachorro-do-mato na sua frente nos últimos } 12 \\
\text { meses? }\end{array}$ & Sim | Não & \\
\hline $\begin{array}{l}\text { 2.2.7 O(A) senhor(a) se lembra de ter visto ou ouvido alguma coisa na TV, no rádio ou } \\
\text { na internet que falava sobre cachorro-do-mato nos últimos } \mathbf{1 2} \text { meses? }\end{array}$ & Sim | Não & \\
\hline $\begin{array}{l}\text { 2.2.8 Alguém da sua família ou algum amigo comentou com o(a) senhor(a) de algum } \\
\text { cachorro-do-mato que tenha aparecido na propriedade deles ou que tenha atacado } \\
\text { alguma criação deles nos últimos } \mathbf{1 2} \text { meses? }\end{array}$ & Sim | Não & \\
\hline $\begin{array}{l}\text { 2.2.9 E agora sobre a onça parda... } \mathrm{O}(\mathrm{A}) \text { senhor(a) já viu alguma onça-parda na sua } \\
\text { frente? Quando foi a última vez que isso aconteceu? } \\
\text { (perguntas introdutórias - anotar o número de meses atrás) }\end{array}$ & Sim | Não & \\
\hline 2.2.10 O(A) senhor(a) viu algum(a) onça parda na sua frente nos últimos 5 anos? & Sim | Não & \\
\hline $\begin{array}{l}\text { 2.2.11 O(A) senhor(a) se lembra de ter visto ou ouvido alguma coisa na TV, no rádio ou } \\
\text { na internet que falava sobre onça parda nos últimos } 5 \text { anos? }\end{array}$ & Sim | Não & \\
\hline $\begin{array}{l}\text { 2.2.12 Alguém da sua família ou algum amigo já comentou com o(a) senhor(a) de } \\
\text { alguma onça parda que tenha aparecido na propriedade deles ou que tenha atacado } \\
\text { alguma criação deles nos últimos } 5 \text { anos? }\end{array}$ & Sim | Não & \\
\hline
\end{tabular}

Nota: Ler ao(à) entrevistado(a) antes de começar as perguntas (ATENÇÃO AOS NOMES DAS ESPÉCIES!):

Agora, gostaria que o(a) senhor(a) respondesse algumas perguntas sobre os prejuízos que o gambá, o cachorro-domato e a onça parda podem já ter trazido para o(a) senhor(a).

\subsection{DANOS: Ataques a ovos e criações causados por GAMBÁ}

2.3.1 O(A) senhor(a) já perdeu animais de criação, incluindo pintinhos, filhotes de outras aves e ovos, por causa de gambá alguma vez na vida? (pergunta introdutória)

2.3.2 Quando foi a última vez que o(a) senhor(a) se deu conta de que perdeu animais de criação, incluindo pintinhos, filhotes de outras aves e ovos, por causa de gambá?

(anotar o número de meses atrás)

2.3.3 E nesses últimos 6 meses, de (preencher com o nome do mês) do ano passado até hoje, o(a) senhor(a) se deu conta de que perdeu animais de criação, incluindo pintinhos, filhotes de outras aves e ovos, por causa de gambá?

2.3.4 Quantas vezes o(a) senhor(a) se deu conta de que perdeu animais de criação, incluindo pintinhos, filhotes de outras aves e ovos, por causa de gambá nos últimos 6 meses?

2.3.5 E nesses últimos 12 meses, de (preencher com o nome do mês) do ano passado até hoje, o(a) senhor(a) se deu conta de que perdeu animais de criação, incluindo pintinhos, filhotes de outras aves e ovos, por causa de gambá?

2.3.6 Quantas vezes o(a) senhor(a) se deu conta de que perdeu animais de criação, incluindo pintinhos, filhotes de outras aves e ovos por causa de gambá nos últimos 12 meses? 
Nota: Se NÃO TEVE DANOS causados por GAMBÁ, ir para a pergunta 2.4 (CACHORRO-DO-MATO).

Nota: Ler ao(à) entrevistado(a) antes de começar as perguntas:

O(A) senhor(a) poderia me contar melhor como foram essas vezes em que o(a) senhor(a) teve algum prejuízo causado por gambá?

\begin{tabular}{|c|c|c|c|}
\hline $\begin{array}{l}\text { 2.3.7 } \\
\text { Evento de ataque } \\
\text { (últimos } 6 \text { meses) }\end{array}$ & $\begin{array}{l}2.3 .8 \\
\text { Qual criação ou o que foi } \\
\text { atacado na __ vez? }\left(1 \underline{a}, 2^{a} \ldots\right)\end{array}$ & $\begin{array}{l}2.3 .9 \\
\text { Quantas cabeças/ovos } \\
\text { foram perdidas? }\end{array}$ & $\begin{array}{l}2.3 .10 \\
\text { Quantas cabeças/ovos tinha } \\
\text { na época do ataque? }\end{array}$ \\
\hline \multicolumn{4}{|l|}{$1^{\circ}$} \\
\hline \multicolumn{4}{|l|}{$2^{\circ}$} \\
\hline \multicolumn{4}{|l|}{$3^{\circ}$} \\
\hline \multicolumn{4}{|l|}{$4^{\circ}$} \\
\hline $\begin{array}{l}2.3 .11 \\
\text { Evento de ataque (entre } \\
\quad 7 \text { e } 12 \text { meses atrás) }\end{array}$ & $\begin{array}{l}2.3 .12 \\
\text { Qual criação ou o que foi } \\
\text { atacado na __ vez? }\left(1 \underline{a}, 2^{\underline{a}} \ldots\right)\end{array}$ & $\begin{array}{l}2.3 .13 \\
\text { Quantas cabeças/ovos } \\
\text { foram perdidas? }\end{array}$ & $\begin{array}{l}2.3 .14 \\
\text { Quantas cabeças/ovos tinha } \\
\text { na época do ataque? }\end{array}$ \\
\hline \multicolumn{4}{|l|}{$1^{\circ}$} \\
\hline \multicolumn{4}{|l|}{$2^{\circ}$} \\
\hline \multicolumn{4}{|l|}{$3^{\circ}$} \\
\hline $4^{\circ}$ & & & \\
\hline
\end{tabular}

Nota: Ler ao(à) entrevistado(a) antes de começar as perguntas:

Agora vamos falar sobre o cachorro-do-mato.

\subsection{DANOS: Ataques a criações causados por CACHORRO-DO-MATO}

2.4.1 O(A) senhor(a) já perdeu animais de criação por causa de cachorro-do-mato alguma vez na vida? (pergunta introdutória)

2.4.2 Quando foi a última vez que o(a) senhor(a) se deu conta de que perdeu animais de criação por causa de cachorro-do-mato?

(anotar o número de meses atrás)

2.4.3 E nesses últimos 12 meses, de (preencher com o nome do mês) do ano passado até hoje, o(a) senhor(a) se deu conta de que perdeu animais de criação por causa de cachorro-domato?

2.4.4 Quantas vezes o(a) senhor(a) se deu conta de que perdeu animais de criação por causa de cachorro-do-mato nos últimos 12 meses?

Nota: Se NÃO TEVE DANOS causados por CACHORRO-DO-MATO, ir para a pergunta 2.5 (ONÇA PARDA).

Nota: Ler ao(à) entrevistado(a) antes de começar as perguntas:

O(A) senhor(a) poderia me contar melhor como foram essas vezes em que o(a) senhor(a) teve algum prejuízo causado por cachorro-do-mato?

\begin{tabular}{|c|l|l|l|}
\hline $\begin{array}{c}2.4 .5 \\
\begin{array}{c}\text { Evento de ataque } \\
\text { (últimos 12 meses) }\end{array}\end{array}$ & $\begin{array}{l}2.4 .6 \\
\text { Qual criação foi atacada na } \\
\text { vez? }\left(1 \underline{\underline{a}}, 2^{a} \ldots\right)\end{array}$ & $\begin{array}{l}2.4 .7 \\
\text { Quantas cabeças foram } \\
\text { perdidas? }\end{array}$ & $\begin{array}{l}2.4 .8 \\
\text { Quantas cabeças tinha na } \\
\text { época do ataque? }\end{array}$ \\
\hline $1^{\circ}$ & & & \\
\hline $2^{\circ}$ & & & \\
\hline $3^{\circ}$ & & & \\
\hline $4^{\circ}$ & & & \\
\hline
\end{tabular}


Nota: Ler ao(à) entrevistado(a) antes de começar as perguntas:

E agora vamos falar sobre a onça parda.

\subsection{DANOS: Ataques a criações causados por ONÇA PARDA}

2.5.1 O(A) senhor(a) já perdeu animais de criação por causa de onça parda alguma vez na vida? (pergunta introdutória)

2.5.2 Quando foi a última vez que o(a) senhor(a) se deu conta de que perdeu animais de criação por causa de onça parda?

(anotar o número de meses atrás)

2.5.3 E nesses últimos 12 meses, de (preencher com o nome do mês) do ano passado até hoje, o(a) senhor(a) se deu conta de que perdeu animais de criação por causa de onça parda?

2.5.4 Quantas vezes o(a) senhor(a) se deu conta de que perdeu animais de criação por causa de onça parda nos últimos 12 meses?

2.5.5 E nesses últimos 5 anos, de de (preencher com o nome do mês e ano) até hoje, o(a) senhor(a) se deu conta de que perdeu animais de criação por causa de onça parda?

2.5.6 Quantas vezes o(a) senhor(a) se deu conta de que perdeu animais de criação por causa de onça parda nos últimos $\mathbf{5}$ anos?

Nota: Se NÃO TEVE DANOS de onça, ir para a pergunta 3.1 (EMOÇÕES).

Nota: Ler ao(à) entrevistado(a) antes de começar as perguntas:

O(A) senhor(a) poderia me contar melhor como foram essas vezes em que o(a) senhor(a) teve algum prejuízo causado por onça parda?

\begin{tabular}{|c|c|c|c|}
\hline $\begin{array}{l}2.5 .7 \\
\text { Evento de ataque } \\
\text { (últimos } 12 \text { meses) }\end{array}$ & $\begin{array}{l}2.5 .8 \\
\text { Qual criação foi atacada na } \\
\text { vez? }\left(1 \underline{a}, 2^{a} \ldots\right)\end{array}$ & $\begin{array}{l}2.5 .9 \\
\text { Quantas cabeças } \\
\text { foram perdidas? }\end{array}$ & $\begin{array}{l}2.5 .10 \\
\text { Quantas cabeças tinha na época do } \\
\text { ataque? }\end{array}$ \\
\hline \multicolumn{4}{|l|}{$1^{\circ}$} \\
\hline \multicolumn{4}{|l|}{$2^{\circ}$} \\
\hline \multicolumn{4}{|l|}{$3^{\circ}$} \\
\hline \multicolumn{4}{|l|}{$4^{\circ}$} \\
\hline $\begin{array}{l}2.5 .11 \\
\text { Evento de ataque (entre } \\
\quad 5 \text { e } 2 \text { anos atrás) }\end{array}$ & $\begin{array}{l}2.5 .12 \\
\text { Qual criação foi atacada na } \\
\text { vez? }\left(1 \underline{\underline{a}}, 2^{a} \ldots\right)\end{array}$ & $\begin{array}{l}2.5 .13 \\
\text { Quantas cabeças } \\
\text { foram perdidas? }\end{array}$ & $\begin{array}{l}2.5 .14 \\
\text { Quantas cabeças tinha na época do } \\
\text { ataque? }\end{array}$ \\
\hline \multicolumn{4}{|l|}{$1^{\circ}$} \\
\hline \multicolumn{4}{|l|}{$2^{\circ}$} \\
\hline \multicolumn{4}{|l|}{$3^{\circ}$} \\
\hline $4^{\circ}$ & & & \\
\hline
\end{tabular}

\section{III - EMOÇÕES ASSOCIADAS À FAUNA}

Nota: Ler ao(à) entrevistado(a) antes de começar as perguntas:

Agora, eu gostaria de saber sobre o que o(a) senhor(a) sente pelo gambá, pelo cachorro-do-mato e pela onça parda quando o(a) senhor(a) PENSA neles e quando o senhor ENCONTRA um deles na sua frente. Vou falar algumas emoções e gostaria que o(a) senhor(a) me dissesse se o(a) senhor(a) sente pouco ou muito delas. Por favor, indique na folha (mostrar a escala para ajudar a responder) se sente nem um pouco ou muito. A bola menor de todas quer dizer que o(a) senhor(a) não sente nem um pouco. Quanto maior o tamanho da bola (correr o dedo da bola menor para a maior), mais o(a) senhor(a) sente. A bola maior de todas quer dizer que o sente muito. 
Quando o(a) senhor(a) PENSA no(a) (espécie), quanto(a) (emoção) o(a) senhor(a) sente? E se o(a) senhor(a) ENCONTRAR o(a) (espécie) na sua frente?

\begin{tabular}{|c|c|c|c|c|c|c|c|c|c|}
\hline 3 EMOÇÃO & Espécie & Contexto & & $\begin{array}{l}\text { Ver } \\
\text { pol }\end{array}$ & & & & $\mathrm{Mu}$ & \\
\hline \multirow{6}{*}{$\begin{array}{c}3.1 \\
\text { Medo }\end{array}$} & \multirow{2}{*}{ 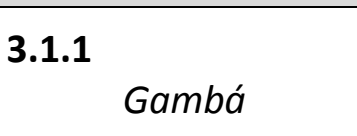 } & 3.1.1.1 Pensar & 1 & 2 & 3 & 4 & 5 & 6 & 7 \\
\hline & & 3.1.1.2 Encontrar & 1 & 2 & 3 & 4 & 5 & 6 & 7 \\
\hline & \multirow{2}{*}{$\begin{array}{l}\text { 3.1.2 } \\
\text { Cachorro-do-mato }\end{array}$} & 3.1.2.1 Pensar & 1 & 2 & 3 & 4 & 5 & 6 & 7 \\
\hline & & 3.1.2.2 Encontrar & 1 & 2 & 3 & 4 & 5 & 6 & 7 \\
\hline & \multirow{2}{*}{$\begin{array}{l}\text { 3.1.3 } \\
\text { Onça parda }\end{array}$} & 3.1.3.1 Pensar & 1 & 2 & 3 & 4 & 5 & 6 & 7 \\
\hline & & 3.1.3.2 Encontrar & 1 & 2 & 3 & 4 & 5 & 6 & 7 \\
\hline \multirow{6}{*}{$\begin{array}{c}3.2 \\
\text { Nojo }\end{array}$} & \multirow{2}{*}{$\begin{array}{ll}3.2 .1 & \\
& \text { Gambá }\end{array}$} & 3.2.1.1 Pensar & 1 & 2 & 3 & 4 & 5 & 6 & 7 \\
\hline & & 3.2.1.2 Encontrar & 1 & 2 & 3 & 4 & 5 & 6 & 7 \\
\hline & \multirow{2}{*}{$\begin{array}{l}\text { 3.2.2 } \\
\text { Cachorro-do-mato }\end{array}$} & 3.2.2.1 Pensar & 1 & 2 & 3 & 4 & 5 & 6 & 7 \\
\hline & & 3.2.2.2 Encontrar & 1 & 2 & 3 & 4 & 5 & 6 & 7 \\
\hline & \multirow{2}{*}{$\begin{array}{l}\text { 3.2.3 } \\
\text { Onça parda }\end{array}$} & 3.2.3.1 Pensar & 1 & 2 & 3 & 4 & 5 & 6 & 7 \\
\hline & & 3.2.3.2 Encontrar & 1 & 2 & 3 & 4 & 5 & 6 & 7 \\
\hline
\end{tabular}

\begin{tabular}{|c|c|c|c|c|c|c|c|c|c|}
\hline \multirow{6}{*}{$\begin{array}{c}3.3 \\
\text { Alegria }\end{array}$} & \multirow{2}{*}{ 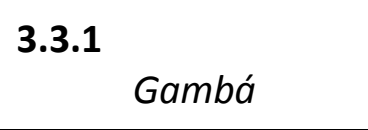 } & 3.3.1.1 Pensar & 1 & 2 & 3 & 4 & 5 & 6 & 7 \\
\hline & & 3.3.1.2 Encontrar & 1 & 2 & 3 & 4 & 5 & 6 & 7 \\
\hline & \multirow{2}{*}{$\begin{array}{l}3.3 .2 \\
\text { Cachorro-do-mato }\end{array}$} & 3.3.2.1 Pensar & 1 & 2 & 3 & 4 & 5 & 6 & 7 \\
\hline & & 3.3.2.2 Encontrar & 1 & 2 & 3 & 4 & 5 & 6 & 7 \\
\hline & \multirow{2}{*}{$\begin{array}{l}\text { 3.3.3 } \\
\text { Onça parda }\end{array}$} & 3.3.3.1 Pensar & 1 & 2 & 3 & 4 & 5 & 6 & 7 \\
\hline & & 3.3.3.2 Encontrar & 1 & 2 & 3 & 4 & 5 & 6 & 7 \\
\hline \multirow{6}{*}{$\begin{array}{c}3.4 \\
\text { Interesse }\end{array}$} & \multirow{2}{*}{$\begin{array}{ll}3.4 .1 & \\
& \text { Gambá }\end{array}$} & 3.4.1.1 Pensar & 1 & 2 & 3 & 4 & 5 & 6 & 7 \\
\hline & & 3.4.1.2 Encontrar & 1 & 2 & 3 & 4 & 5 & 6 & 7 \\
\hline & \multirow{2}{*}{$\begin{array}{l}3.4 .2 \\
\text { Cachorro-do-mato }\end{array}$} & 3.4.2.1 Pensar & 1 & 2 & 3 & 4 & 5 & 6 & 7 \\
\hline & & 3.4.2.2 Encontrar & 1 & 2 & 3 & 4 & 5 & 6 & 7 \\
\hline & \multirow{2}{*}{$\begin{array}{l}\text { 3.4.3 } \\
\text { Onça parda }\end{array}$} & 3.4.3.1 Pensar & 1 & 2 & 3 & 4 & 5 & 6 & 7 \\
\hline & & 3.4.3.2 Encontrar & 1 & 2 & 3 & 4 & 5 & 6 & 7 \\
\hline
\end{tabular}

\section{IV - CRENÇAS E PERCEPÇÃO DE RISCO ASSOCIADO À FAUNA}

Nota: Ler ao(à) entrevistado(a) antes de começar as perguntas:

Agora, vou falar algumas frases para cada um dos três animais e gostaria que o(a) senhor(a) me indicasse o quanto o(a) senhor(a) concorda com as frases. Para cada frase, por favor, aponte sua resposta nas bolas dessa folha. Agora, a bola menor (apontar a bola pequena) significa que o(a) senhor(a) não concorda nem um pouco; quanto maior o tamanho das bolas (apontar a bolas grandes), mais o(a) senhor(a) concorda com a frase. A bola maior de todas significa que o(a) senhor(a) concorda muito com a frase. 
Para o(a) senhor(a):

\begin{tabular}{|l|c|c|c|c|c|c|c|c|}
\hline $\begin{array}{l}\text { 4.1 FORÇA das crenças relacionadas aos benefícios } \\
\text { associados à fauna }\end{array}$ & \multicolumn{2}{|c|}{ Espécie } & \multicolumn{2}{|c|}{ Nem } \\
um pouco
\end{tabular}

Nota: Ler ao(à) entrevistado(a) antes de começar as perguntas:

Agora, gostaria que o(a) senhor(a) me dissesse o quanto cada uma dessas coisas são importantes para a sua vida e para as decisões que o(a) senhor(a) toma, desde nada importante para o(a) senhor(a) (apontar a bola menor), até muito importante para o(a) senhor(a) (apontar a bola maior). Para cada frase, por favor, me diga o quanto o senhor acha ser importante o que eu vou dizer. Para o(a) senhor(a):

\begin{tabular}{|c|c|c|c|c|c|c|c|}
\hline $\begin{array}{l}\text { 4.2 AVALIAÇÃO das crenças relacionadas aos benefícios associados à } \\
\text { fauna }\end{array}$ & & $\begin{array}{l}\text { ada } \\
\text { orta }\end{array}$ & & & & & \\
\hline 4.2.1 Turistas serem atraídos para região é: & 1 & 2 & 3 & 4 & 5 & 6 & 7 \\
\hline 4.2.2 Os animais que podem causar problemas serem controlados é: & 1 & 2 & 3 & 4 & 5 & 6 & 7 \\
\hline 4.2.3 As sementes de árvores frutíferas serem espalhadas é: & 1 & 2 & 3 & 4 & 5 & 6 & 7 \\
\hline 4.2.4 Estudos e pesquisas sobre os animais da natureza são: & 1 & 2 & 3 & 4 & 5 & 6 & 7 \\
\hline 4.2.5 Saber que os animais estão bem e vivos na natureza é: & 1 & 2 & 3 & 4 & 5 & 6 & 7 \\
\hline 4.2.6 Saber que as crianças vão conhecer os animais da natureza é: & 1 & 2 & 3 & 4 & 5 & 6 & 7 \\
\hline
\end{tabular}

Nota: Ler ao(à) entrevistado(a) antes de começar as perguntas:

Agora, vou falar várias frases e gostaria que o(a) senhor(a) me indicasse, na sua opinião, qual a chance dessas coisas acontecerem. Para cada frase, por favor, mostre sua resposta nas bolas dessa folha. A bola menor é para coisas que o(a) senhor(a) acha que não tem a menor chance de acontecer. Quanto maior o tamanho da bola, quer dizer que tem mais chance de acontecer. A bola maior é para coisas que o(a) senhor(a) acha que tem muita chance de acontecer. 
Para o(a) senhor(a), qual a CHANCE de um(a):

\begin{tabular}{|c|c|c|c|c|c|c|c|c|c|}
\hline 4.3 Componente COGNITIVO da percepção de risco & Espécie & Tempo & \multicolumn{5}{|c|}{$\begin{array}{l}\text { Nenhuma } \\
\text { chance }\end{array}$} & \multicolumn{2}{|c|}{$\begin{array}{l}\text { Muita } \\
\text { chance }\end{array}$} \\
\hline \multirow{3}{*}{$\begin{array}{l}\text { 4.3.1 (Espécie) atacar seus ovos/animais de criação } \\
\text { nos próximos (tempo)? }\end{array}$} & Gambá & 6 meses & 1 & 2 & 3 & 4 & 5 & 6 & 7 \\
\hline & Cachorro & 12 meses & 1 & 2 & 3 & 4 & 5 & 6 & 7 \\
\hline & Onça & 5 anos & 1 & 2 & 3 & 4 & 5 & 6 & 7 \\
\hline \multirow{3}{*}{$\begin{array}{l}\text { 4.3.2 (Espécie) atacar pessoas nos próximos } \\
\text { (tempo)? }\end{array}$} & Gambá & 6 meses & 1 & 2 & 3 & 4 & 5 & 6 & 7 \\
\hline & Cachorro & 12 meses & 1 & 2 & 3 & 4 & 5 & 6 & 7 \\
\hline & Onça & 5 anos & 1 & 2 & 3 & 4 & 5 & 6 & 7 \\
\hline \multirow{3}{*}{$\begin{array}{l}\text { 4.3.1 (Espécie) transmitir alguma doença para seus } \\
\text { animais de criação nos próximos (tempo)? }\end{array}$} & Gambá & 6 meses & 1 & 2 & 3 & 4 & 5 & 6 & 7 \\
\hline & Cachorro & 12 meses & 1 & 2 & 3 & 4 & 5 & 6 & 7 \\
\hline & Onça & 5 anos & 1 & 2 & 3 & 4 & 5 & 6 & 7 \\
\hline \multirow{3}{*}{$\begin{array}{l}\text { 4.3.4 (Espécie) transmitir alguma doença para as } \\
\text { pessoas é nos próximos (tempo)? }\end{array}$} & Gambá & 6 meses & 1 & 2 & 3 & 4 & 5 & 6 & 7 \\
\hline & Cachorro & 12 meses & 1 & 2 & 3 & 4 & 5 & 6 & 7 \\
\hline & Onça & 5 anos & 1 & 2 & 3 & 4 & 5 & 6 & 7 \\
\hline
\end{tabular}

Nota: Ler ao(à) entrevistado(a) antes de começar as perguntas:

Agora gostaria de saber o quão preocupado o(a) senhor(a) fica ao pensar em cada uma dessas situações que eu acabei de falar. Quanto menor a bola (apontar a bola menor), menos preocupado(a) o(a) senhor(a) fica e quanto maior a bola (apontar a bola maior), mais preocupado(a) o(a) senhor(a) fica.

Quão PREOCUPADO(A) o(a) senhor(a) fica de que:

\begin{tabular}{|c|c|c|c|c|c|c|c|c|}
\hline \multirow{4}{*}{$\begin{array}{l}\text { 4.4 Componente AFETIVO da percepção de risco } \\
\begin{array}{l}\text { 4.4.1 Um(a) (espécie) aqui da vizinhança ataque os } \\
\text { ovos/animais de criação desta propriedade? }\end{array}\end{array}$} & \multirow{2}{*}{$\begin{array}{l}\text { Espécie } \\
\text { Gambá }\end{array}$} & \multicolumn{3}{|c|}{$\begin{array}{c}\text { Nada } \\
\text { preocupado }\end{array}$} & \multicolumn{4}{|c|}{$\begin{array}{l}\text { Muito } \\
\text { preocupado }\end{array}$} \\
\hline & & 1 & 2 & 3 & 4 & 5 & 6 & 7 \\
\hline & Cachorro & 1 & 2 & 3 & 4 & 5 & 6 & 7 \\
\hline & Onça & 1 & 2 & 3 & 4 & 5 & 6 & 7 \\
\hline \multirow{3}{*}{$\begin{array}{l}\text { 4.4.2 Um(a) (espécie) aqui da vizinhança ataque pessoas aqui da } \\
\text { região? }\end{array}$} & Gambá & 1 & 2 & 3 & 4 & 5 & 6 & 7 \\
\hline & Cachorro & 1 & 2 & 3 & 4 & 5 & 6 & 7 \\
\hline & Onça & 1 & 2 & 3 & 4 & 5 & 6 & 7 \\
\hline \multirow{3}{*}{$\begin{array}{l}\text { 4.4.3 Um(a) (espécie) aqui da vizinhança transmita doenças } \\
\text { para os animais de criação da sua propriedade? }\end{array}$} & Gambá & 1 & 2 & 3 & 4 & 5 & 6 & 7 \\
\hline & Cachorro & 1 & 2 & 3 & 4 & 5 & 6 & 7 \\
\hline & Onça & 1 & 2 & 3 & 4 & 5 & 6 & 7 \\
\hline \multirow{3}{*}{$\begin{array}{l}\text { 4.4.4 Um(a) (espécie) aqui da vizinhança transmita doenças } \\
\text { para pessoas aqui da região? }\end{array}$} & Gambá & 1 & 2 & 3 & 4 & 5 & 6 & 7 \\
\hline & Cachorro & 1 & 2 & 3 & 4 & 5 & 6 & 7 \\
\hline & Onça & 1 & 2 & 3 & 4 & 5 & 6 & 7 \\
\hline
\end{tabular}

\section{V - ATITUDE E TOLERÂNCIA EM RELAÇÃO À FAUNA}

Nota: Ler ao(à) entrevistado(a) antes de começar as perguntas:

Gostaria de saber agora a sua opinião a respeito desses animais. Vou começar a falar algumas frases e gostaria que para cada uma dessas frases o(a) senhor(a) completasse com uma opção de acordo com o que o(a) senhor(a) acha. Lembrando que não tem uma resposta certa. Por favor, mostre na escala o quão (1ㅇ extremo) (apontar a bola azul maior) ou (2e extremo) (apontar a bola laranja maior) o(a) senhor(a) acha que o animal é. 
5.1 ATITUDE EM RELAÇÃO À FAUNA - O(A) senhor(a) acha que o/a (espécie) é:

\begin{tabular}{|c|c|c|c|c|c|c|c|}
\hline 5.1.1 & \multicolumn{5}{|c|}{ Muito ruim } & \multicolumn{2}{|c|}{ Muito bom } \\
\hline Gambá & -3 & -2 & -1 & 0 & 1 & 2 & 3 \\
\hline Cachorro-do-mato & -3 & -2 & -1 & 0 & 1 & 2 & 3 \\
\hline Onça parda & -3 & -2 & -1 & 0 & 1 & 2 & 3 \\
\hline 5.1 .2 & \multicolumn{5}{|c|}{ Muito chato } & \multicolumn{2}{|c|}{ Muito legal } \\
\hline Gambá & -3 & -2 & -1 & 0 & 1 & 2 & 3 \\
\hline Cachorro-do-mato & -3 & -2 & -1 & 0 & 1 & 2 & 3 \\
\hline Onça parda & -3 & -2 & -1 & 0 & 1 & 2 & 3 \\
\hline 5.1.3 & \multicolumn{5}{|c|}{ Muito prejudicial } & \multicolumn{2}{|c|}{ Muito benéfico } \\
\hline Gambá & -3 & -2 & -1 & 0 & 1 & 2 & 3 \\
\hline Cachorro-do-mato & -3 & -2 & -1 & 0 & 1 & 2 & 3 \\
\hline Onça parda & -3 & -2 & -1 & 0 & 1 & 2 & 3 \\
\hline 5.1 .4 & \multicolumn{4}{|c|}{ Muito desagradável } & \multicolumn{3}{|c|}{ Muito agradável } \\
\hline Gambá & -3 & -2 & -1 & 0 & 1 & 2 & 3 \\
\hline Cachorro-do-mato & -3 & -2 & -1 & 0 & 1 & 2 & 3 \\
\hline Onça parda & -3 & -2 & -1 & 0 & 1 & 2 & 3 \\
\hline 5.1 .5 & \multicolumn{4}{|c|}{ Muito feio } & \multicolumn{3}{|c|}{ Muito bonito } \\
\hline Gambá & -3 & -2 & -1 & 0 & 1 & 2 & 3 \\
\hline Cachorro-do-mato & -3 & -2 & -1 & 0 & 1 & 2 & 3 \\
\hline Onça parda & -3 & -2 & -1 & 0 & 1 & 2 & 3 \\
\hline
\end{tabular}

Nota: Ler ao(à) entrevistado(a) antes de começar as perguntas:

Gostaria de saber por fim a sua opinião a respeito da quantidade desses animais. Vou começar a falar algumas frases e gostaria que para cada uma o(a) senhor(a) completasse com uma opção de acordo com o que o(a) senhor(a) acha. Por favor, mostre na folha o quanto o(a) senhor(a) acha que a quantidade desses animais é ou deveria ser, desde muito (1ํ extremo) (apontar a bola azul maior) até muito (2 extremo) (apontar a bola laranja maior). Igual às outras, não tem uma resposta certa, o que conta é o que o(a) senhor(a) acha.

\subsection{TOLERÂNCIA EM RELAÇÃO À FAUNA: TAMANHO DAS POPULAÇÕES}

\subsubsection{Na sua opinião, a quantidade de (espécie) hoje em dia aqui} na região está:

\begin{tabular}{|c|c|c|c|c|c|c|c|}
\hline Gambá & 7 & 6 & 5 & 4 & 3 & 2 & 1 \\
\hline Cachorro-do-mato & 7 & 6 & 5 & 4 & 3 & 2 & 1 \\
\hline Onça parda & 7 & 6 & 5 & 4 & 3 & 2 & 1 \\
\hline $\begin{array}{l}\text { 5.2.2 Na sua opinião, a quantidade de (espécie) aqui na região } \\
\text { deveria ser maior ou menor do que é hoje? Quanto? }\end{array}$ & \multicolumn{5}{|c|}{ Muito menor } \\
\hline Gambá & -3 & -2 & -1 & 0 & 1 & 2 & 3 \\
\hline Cachorro-do-mato & -3 & -2 & -1 & 0 & 1 & 2 & 3 \\
\hline Onça parda & -3 & -2 & -1 & 0 & 1 & 2 & 3 \\
\hline $\begin{array}{l}\text { 5.2.3 E agora, pensando numa área ainda maior, como o estado } \\
\text { de São Paulo por exemplo, na sua opinião, a quantidade de } \\
\text { (espécie) deveria ser maior ou menor do que é hoje? Quanto? }\end{array}$ & Muito menor & \multicolumn{1}{|l|}{ igual } & \multicolumn{1}{|c|}{ Muito maior } \\
\hline Gambá & -3 & -2 & -1 & 0 & 1 & 2 & 3 \\
\hline Cachorro-do-mato & -3 & -2 & -1 & 0 & 1 & 2 & 3 \\
\hline Onça parda & -3 & -2 & -1 & 0 & 1 & 2 & 3 \\
\hline
\end{tabular}




\section{VI - DADOS SOCIODEMOGRÁFICOS E CARACTERÍSTICAS DA PROPRIEDADE - PARTE II}

Nota: Ler ao(à) entrevistado(a) antes de começar as perguntas:

Já estamos quase acabando, para finalizar, gostaria apenas de saber mais algumas informações sobre o(a) senhor(a) e sua casa.

6.1. Idade: $O(A)$ senhor(a) pode me dizer a data do seu nascimento? Dia $|\ldots|$ Mês $\mid \ldots \ldots$ _ Ano $\mid \_\ldots$

6.2. Profissão/atividade: $O(A)$ senhor(a) diria que a sua principal atividade, ou seja, aquela na qual o(a) senhor(a) passa a maior parte do tempo é:

cuidar de plantações ou de animais de criação, ou outras atividades na sua propriedade I__

uma atividade na cidade, como trabalhar no comércio ou fazendo algum serviço I__ I OU

outra I__ Qual?

6.3.1. Escolaridade: $\mathrm{O}(\mathrm{A})$ senhor(a) já estudou em alguma escola?

Sim I__ N Não I__ I Nota: Se NÃO, vá para a pergunta 11.4.1.

6.3.2.1. Escolaridade: Até qual série o(a) senhor(a) completou seus estudos? (anotar a série e o nível) série

6.3.2.2. Infantil I__ I Fundamental I__ Médio I__

Nota: Se não completou o MÉDIO vá para a pergunta 11.4.1.

6.3.3.1. Escolaridade: $O(A)$ senhor(a) fez faculdade? Sim I__ I Não fez |

6.3.3.2. Completa? (anotar sim ou não)

11.3.3.3. Quantos anos?

Nota: Se NÃO ou NÃO COMPLETA, vá para a pergunta 11.4.1.

6.3.4.1. Escolaridade: $O(A)$ senhor(a) fez algum curso de pós-graduação? Sim I Não fez

6.3.4.2. Completa? (anotar sim ou não)

11.3.4.3. Quantos anos?

Nota: Se NÃO ou NÃO COMPLETA, vá para a pergunta 11.4.1.

6.4.1. Riqueza: Da lista de itens que vou falar a seguir, gostaria que o(a) senhor(a) me dissesse se o(a) senhor(a) ou alguém aqui da sua casa tem alguma destas coisas. Se não tiver, não tem problema.

\begin{tabular}{|l|l|l|l|l|l|}
\hline \multicolumn{1}{|c|}{ Item } & Quant. & \multicolumn{1}{c|}{ Item } & Quant. & \multicolumn{1}{c|}{ Item } & Quant. \\
\hline Trator & & Fogão a gás de 4 bocas & & Telefone fixo & \\
\hline Carroça & & Fogão a gás de 5/6 bocas & & Telefone celular & \\
\hline Carro & & Micro-ondas & & Computador & \\
\hline Moto & Tanquinho & & Tablet & \\
\hline Bicicleta & Máquina de lavar roupa & & Ventilador & \\
\hline Gerador de luz & Televisão & & Panela de pressão & \\
\hline Geladeira & DVD & & Liquidificador & \\
\hline Freezer & Aparelho de som & Batedeira & \\
\hline Forno elétrico & Antena parabólica/satélite & & Banheiros & \\
\hline
\end{tabular}

Nota: Ler ao(à) entrevistado(a) para finalizar:

Gostaríamos de agradecer imensamente pela sua disposição em nos receber e por todas as suas respostas. A sua participação é muito importante para o sucesso desse estudo! 


\section{Appendix $\mathbf{J}$ - Defining the distributions and link functions}

Prior to the analyses, we used the function descdist (fitdistrplus package; DelignetteMuller \& Dutang, 2015), in $\mathrm{R}$ environment ( $\mathrm{R}$ Core Team, 2016) to evaluate the best probability distribution and link function to model each dependent variable (Table J1). Given that some variables best fitted a beta distribution, which is not available in the package used for the analysis (Piecewise SEM; Lefcheck, 2016), we modeled these variables using the similar Gaussian distribution with a logit function. For these variables, all values were then divided by the maximum value of the index/scale to be constrained between 0 and 1 , as required to use logit link.

Table J1. Family distributions and link functions used to model the response variables in the Piecewise SEM analysis for the models of how the ecological context affects tolerance towards opossum (Didelphis aurita), crab-eating fox (Cerdocyon thous) and puma (Puma concolor).

\begin{tabular}{lccc}
\hline Variables & Species & Family distribution & Link function \\
\hline \multirow{2}{*}{ Tolerance } & Opossum & gaussian & identity \\
\cline { 2 - 4 } & Crab-eating fox & gamma & log \\
\hline $\begin{array}{l}\text { Attitude } \\
\text { Positive beliefs }\end{array}$ & Opossuma & & \\
Negative beliefs & Crab-eating fox & gaussian & logit \\
Negative emotions & Puma & & log \\
\hline & Opossum & gamma & logit \\
Positive emotions & Crab-eating fox & gaussian & logit \\
\cline { 2 - 4 } & Puma & & \\
\hline Contact & Opossum & binomial & \\
Damage & Crab-eating fox & & \\
\hline
\end{tabular}

We also calculated variance inflation factor (VIF) to test for the collinearity between variables (Table J2). VIF values higher than 5 indicate multicollinearity problem (Sheather, 2009), but all values were below this threshold (Table J2). 
Table J2. Variation inflation factor (VIF) among variables used in the models of how the ecological context affects tolerance towards the opossums (Didelphis aurita), crab-eating foxes (Cerdocyon thous) and pumas (Puma concolor).

\begin{tabular}{lccc}
\hline Variables & Opossum & $\begin{array}{c}\text { Species } \\
\text { Crab-eating fox }\end{array}$ & Puma \\
\hline Contact & 1.18 & 1.11 & 1.16 \\
Damage & 1.06 & 1.10 & 1.11 \\
Positive beliefs & 1.60 & 1.79 & 1.88 \\
Negative beliefs & 1.21 & 1.40 & 1.59 \\
Negative emotions & 1.13 & 1.13 & 1.48 \\
Positive emotions & 1.63 & 1.65 & 2.16 \\
Attitude & 1.89 & 1.75 & 2.40 \\
\hline
\end{tabular}

\section{References}

Delignette-Muller, M.L. \& Dutang, C. 2015. fitdistrplus: An R package for fitting distributions. Journal of Statistical Software, 64, 1-34. URL http://www.jstatsoft.org/v64/i04/

Lefcheck, J.S. 2016. Piecewise Structural Equation Modeling (Version 1.2.1). Retrieved from https://CRAN.R-project.org/package=piecewiseSEM.

R Core Team. 2016. R: A language and environment for statistical computing, $\mathrm{R}$ Foundation for Statistical Computing, Vienna, Austria. URL https://www.R-project.org/.

Sheather, S. 2009. A Modern Approach to Regression with R. Springer, New York. 


\section{Appendix K - Inclusion of the missing paths suggested by the analysis}

In Piecewise Structural Equation Modeling (SEM), it is possible to re-specify the proposed model by including significant missing paths indicated by the analysis when the model fit is not good $(\mathrm{p}<0.05)$. After running the initial conceptual models for each of the target species, i.e., the opossum (Didelphis aurita; Table K1), the crab-eating fox (Cerdocyon thous; Table K2) and the puma (Puma concolor, Table K3), we checked the model fit. Given that the initial models did not present a good fit, we included the most significant missing paths suggested by the analysis, one at a time (except when p-values of missing paths were lower than 0.0001 as observed for the puma, in which case we included both missing paths at once) and checked the model fit after each inclusion. We proceeded until the model acquired a good fit. For all three species, only two missing paths were included in the final model. It is important to highlight though that all included missing links correspond to relationships between emotions and beliefs. As such, all these links are conceptually plausible, as emotions are beliefs about feelings (see main text - Conceptual model). 
Table K1. Results of the Piecewise Structural Equation Model analyses for the conceptual models on how the ecological context affects tolerance towards the opossum (Didelphis aurita). Spatial scale = spatial scale at which the proportion of native forest cover around participants' households was computed; DF = degrees of freedom; Akaike's Information Criterion corrected for small samples (AICc); $\triangle \mathrm{AICc}=\mathrm{Difference}$ between AICc values of each model in relation the model with the lowest AICc value; $\mathrm{K}=$ Likelihood degrees of freedom; NE $=$ Negative emotions; $\mathrm{PE}=$ Positive emotions; $\mathrm{PB}=$ Positive beliefs. Missing path included in each step is highlighted (grey shadow). Equally plausible models $(\triangle \mathrm{AICc}<2)$ are indicated with an asterisk $(*)$.

\begin{tabular}{|c|c|c|c|c|c|c|c|c|c|}
\hline \multirow[t]{2}{*}{ Model } & \multirow{2}{*}{$\begin{array}{c}\text { Spatial } \\
\text { scale }\end{array}$} & \multirow[t]{2}{*}{ Fisher's C } & \multirow[t]{2}{*}{ DF } & \multirow[t]{2}{*}{ p-value } & \multirow[t]{2}{*}{ AICc } & \multirow[t]{2}{*}{$\triangle \mathrm{AICc}$} & \multirow[t]{2}{*}{$\mathbf{K}$} & \multicolumn{2}{|c|}{$\begin{array}{l}\text { Missing paths included } \\
\text { (response } \sim \text { predictor) }\end{array}$} \\
\hline & & & & & & & & $\mathrm{NE} \sim \mathrm{PE}$ & $\mathbf{P E} \sim \mathbf{P B}$ \\
\hline \multirow{3}{*}{ Initial model } & $1 \mathrm{~km}$ & 91.87 & 42 & $<0.05$ & 203.87 & 6.10 & 37 & $<0.0001$ & 0.0201 \\
\hline & $1.5 \mathrm{~km}$ & 85.77 & 42 & $<0.05$ & 197.77 & 0.00 & 37 & $<0.0001$ & 0.0201 \\
\hline & $2 \mathrm{~km}$ & 95.02 & 42 & $<0.05$ & 207.02 & 9.25 & 37 & $<0.0001$ & 0.0201 \\
\hline \multirow{3}{*}{$\begin{array}{l}\text { Intermediate } \\
\text { model }\end{array}$} & $1 \mathrm{~km}$ & 60.13 & 40 & $<0.05$ & 176.73 & 0.49 & 38 & - & 0.0201 \\
\hline & $1.5 \mathrm{~km}$ & 59.64 & 40 & $<0.05$ & 176.24 & 0.00 & 38 & - & 0.0201 \\
\hline & $2 \mathrm{~km}$ & 62.72 & 40 & $<0.05$ & 179.32 & 3.08 & 38 & - & 0.0201 \\
\hline \multirow{2}{*}{ Final model } & $0.5 \mathrm{~km}$ & 53.06 & 38 & 0.053 & 174.39 & 3.16 & 39 & - & - \\
\hline & $1 \mathrm{~km} *$ & 50.31 & 38 & 0.087 & 171.64 & 0.41 & 39 & - & - \\
\hline
\end{tabular}


Table K2. Results of the Piecewise Structural Equation Model analyses for the conceptual models on how the ecological context affects tolerance towards the crab-eating fox (Cerdocyon thous). Spatial scale $=$ spatial scale at which the proportion of native forest cover around participants' households was computed; $\mathrm{DF}=$ degrees of freedom; Akaike's Information Criterion corrected for small samples $(\mathrm{AICc}) ; \mathrm{AICc}=$ Difference between AICc values of each model in relation the model with the lowest AICc value; $\mathrm{K}=$ Likelihood degrees of freedom; PE $=$ Positive emotions; $\mathrm{PB}=$ Positive beliefs; $\mathrm{NB}=$ Negative beliefs; $\mathrm{T}=$ Tolerance; $\mathrm{NE}=$ Negative emotions. Missing path included in each step is highlighted (grey shadow). Equally plausible models $(\triangle \mathrm{AICc}<2)$ are indicated with an asterisk $\left(^{*}\right)$.

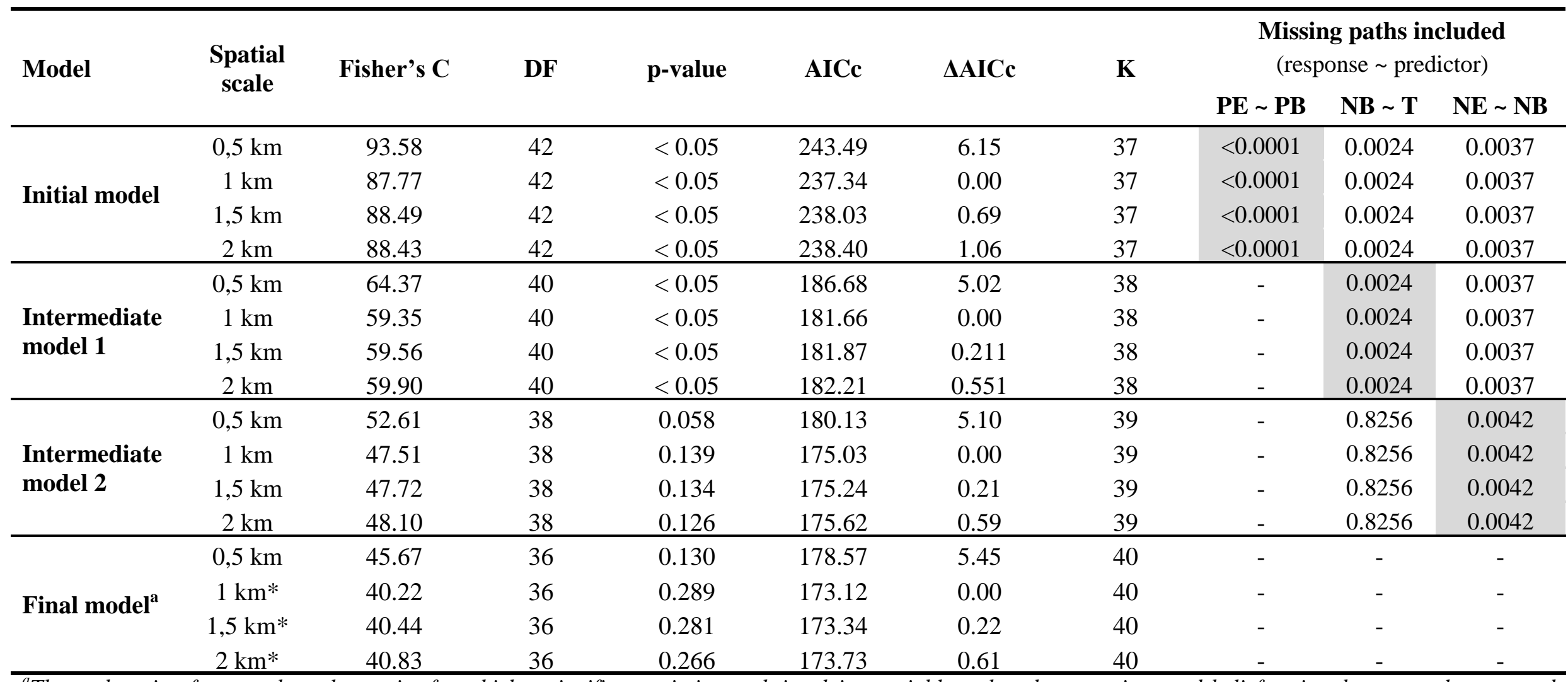

${ }^{a}$ The crab-eating fox was the only species for which a significant missing path involving variables other than emotions and beliefs - i.e., between tolerance and negative beliefs - was indicated by the Piecewise SEM analyses. However, after including this missing path, the coefficient became insignificant (p > 0.05), reason why we also included the next significant missing path, in this case related to emotions and beliefs (negative emotions and negative beliefs). Because the missing path between tolerance and negative beliefs remained insignificant after this inclusion, we did not included it in the final model. 
Table K3. Results of the Piecewise Structural Equation Model analyses for the conceptual models on how the ecological context affects tolerance towards the puma (Puma concolor). Spatial scale = spatial scale at which the proportion of native forest cover around participants' households was computed; DF $=$ degrees of freedom; Akaike's Information Criterion corrected for small samples (AICc); $\triangle \mathrm{AICc}=\mathrm{Difference}$ between AICc values of each model in relation the model with the lowest AICc value; $\mathrm{K}=$ Likelihood degrees of freedom; PE $=$ Positive emotions; $\mathrm{PB}=$ Positive beliefs; $\mathrm{NE}=$ Negative emotions; $\mathrm{NB}=$ Negative beliefs. Missing path included in each step is highlighted (grey shadow). Equally plausible models $(\triangle \mathrm{AICc}<2)$ are indicated with an asterisk $(*)$.

\begin{tabular}{|c|c|c|c|c|c|c|c|c|c|}
\hline \multirow[t]{2}{*}{ Model } & \multirow[t]{2}{*}{ Spatial scale } & \multirow[t]{2}{*}{ Fisher's C } & \multirow[t]{2}{*}{ DF } & \multirow[t]{2}{*}{ p-value } & \multirow[t]{2}{*}{$\mathrm{AICc}$} & \multirow[t]{2}{*}{$\triangle \mathrm{AICc}$} & \multirow[t]{2}{*}{$\mathbf{K}$} & \multicolumn{2}{|c|}{$\begin{array}{l}\text { Missing paths included } \\
\text { (response } \sim \text { predictor) }\end{array}$} \\
\hline & & & & & & & & $\mathbf{P E} \sim \mathbf{P B}$ & $\mathbf{N E} \sim \mathbf{N B}$ \\
\hline \multirow{3}{*}{ Initial model } & $1 \mathrm{~km}$ & 103.34 & 42 & $<0.05$ & 221.28 & 0.87 & 37 & $<0.0001$ & $<0.0001$ \\
\hline & $1,5 \mathrm{~km}$ & 102.47 & 42 & $<0.05$ & 220.41 & 0.00 & 37 & $<0.0001$ & $<0.0001$ \\
\hline & $2 \mathrm{~km}$ & 102.83 & 42 & $<0.05$ & 220.77 & 0.36 & 37 & $<0.0001$ & $<0.0001$ \\
\hline \multirow{3}{*}{ Final model } & $1 \mathrm{~km} *$ & 40.13 & 38 & 0.376 & 168.45 & 0.96 & 39 & - & - \\
\hline & $1,5 \mathrm{~km} *$ & 39.25 & 38 & 0.414 & 167.57 & 0.08 & 39 & - & - \\
\hline & $2 \mathrm{~km} *$ & 39.17 & 38 & 0.417 & 167.49 & 0.00 & 39 & - & - \\
\hline
\end{tabular}

